\title{
Caucasus Seismic Information Network: Data and Analysis, Final Report
}

\author{
Contract No. DE-AC52-03NA99600 \\ Submitted to: \\ Department of Energy \\ National Nuclear Security Administration
}

\author{
Submitted by \\ New England Research, Inc. \\ 331 Olcott Drive, Suite L1 \\ White River Junction, VT 05001
}

Administrative Contact

Beth K. Potter

New England Research, Inc.

331 Olcott Drive, Suite L1

White River Junction, VT 05001

Phone: 802/296-2401 Ext. 113

Fax: 802/296-8333

Email: beth@ner.com
Principal Investigator

Randolph J. Martin, III

New England Research, Inc. 331 Olcott Drive, Suite L1

White River Jct., VT 05001

Phone: 802/296-2401 Ext. 120

Fax: 802/296-8333

Email randy@ner.com

Proposed Period of Performance:

September 2003 - December 2006

Submitted

February 22, 2007 


\section{Outline}

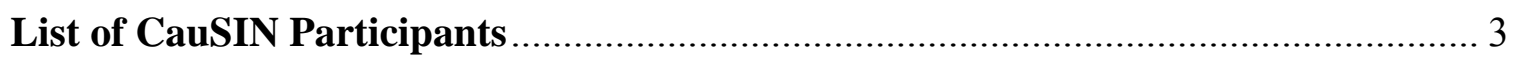

\section{Chapter 1: Introduction}

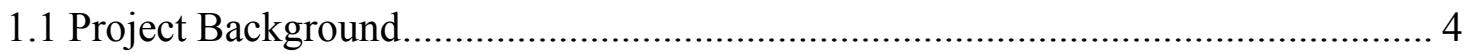

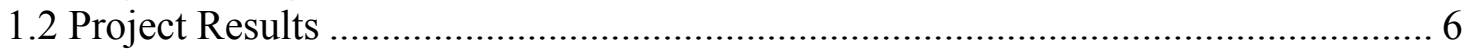

1.2 .1 Geology

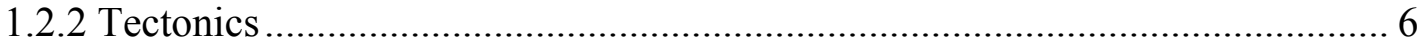

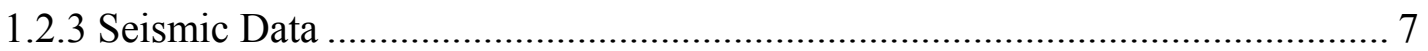

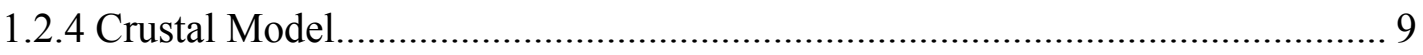

Chapter 2: Tectonics of the Caucasus and Border Regions: Some Major Features and Problems

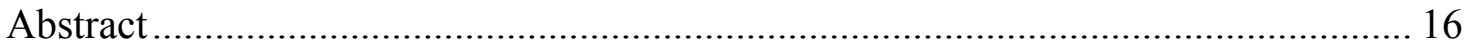

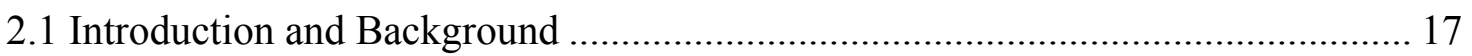

2.2 Continental Collision, the Bitlis-Zagros Suture zone, and the Zagros ………....... 17

2.3 The Caucasus Region....................................................................................... 20

2.3.1 South Caspian Subduction Hypothesis ....................................................... 20

2.3.2 The Greater and Lesser Caucasus ............................................................ 23

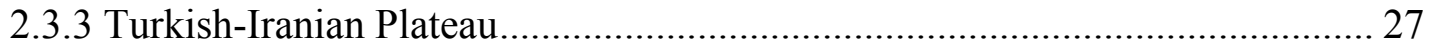

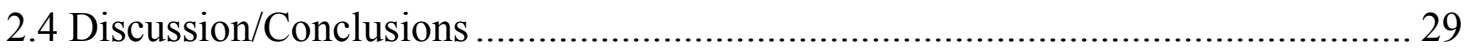

Chapter 3: The Borjomi-Kazbegi Fault: Geological and Geophysical Study Results

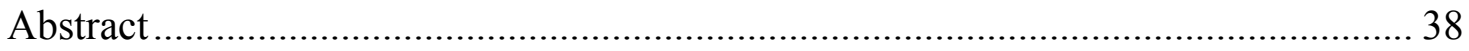

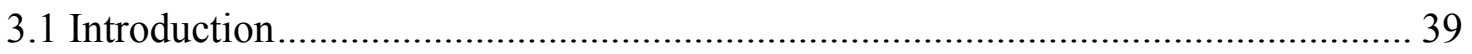

3.2 Tectonic Models Of the Borjomi-Kazbegi Region................................................. 40

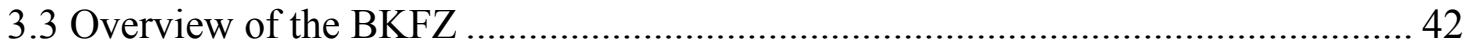

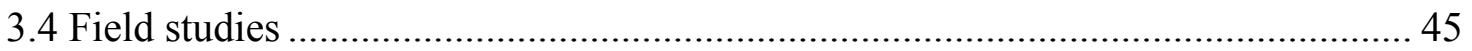

3.4.1 Geological Results in the Lesser Caucasus and Transcaucasus....................... 46

3.4.2 Geophysical Results in the Lesser Caucasus .................................................. 49

3.4.3 Geological Results in the Greater Caucasus ................................................ 51

3.4.4 Geophysical Results in the Greater Caucasus.............................................. 52

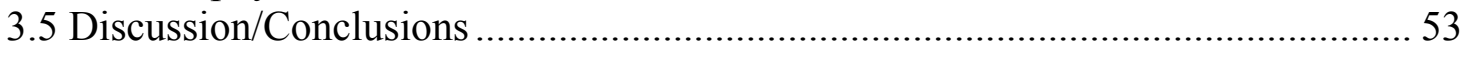

Chapter 4: Crustal Structure of Caucasus and Surrounding Regions from P-wave Travel-time Tomography

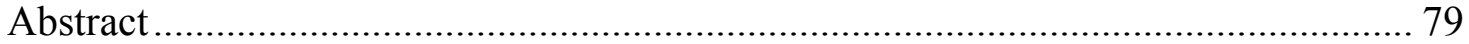

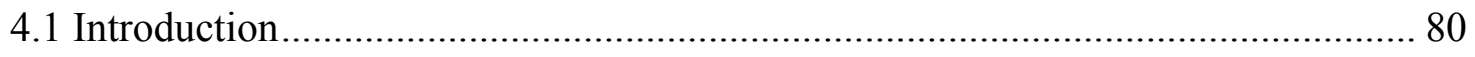

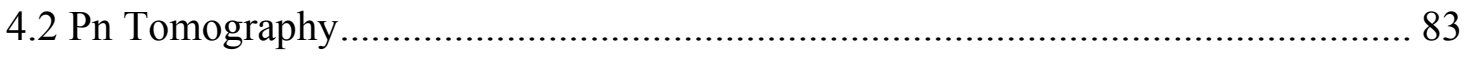

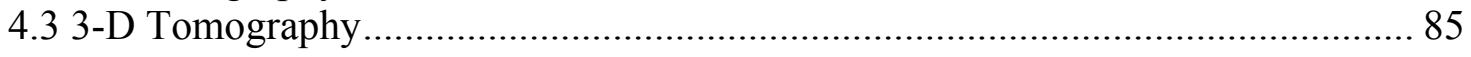

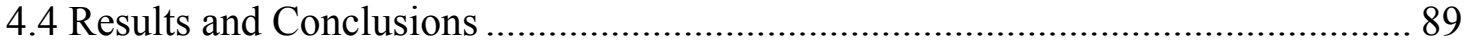




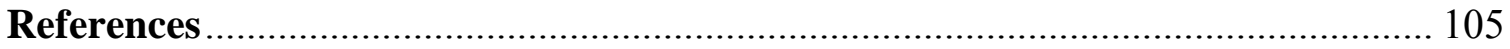

\section{Appendix A: Summary of Project Database}

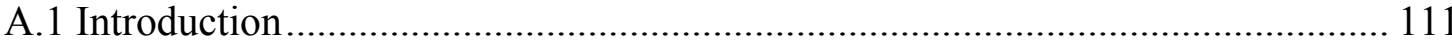

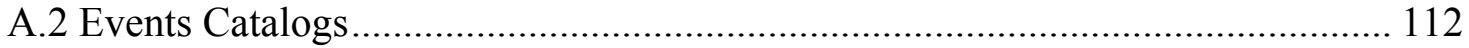

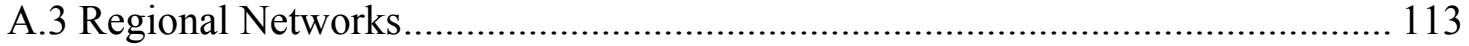

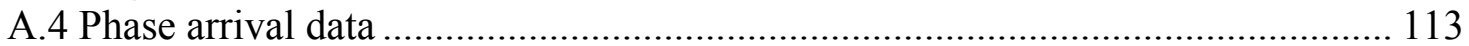

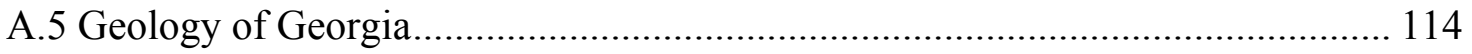

Caucasus, seismicity, crustal structure, tectonics, active faulting, regional networks, seismic data 


\section{List of CauSIN Participants}

\section{Active Participants (by affiliation)}

$\begin{array}{llr}\text { Emanuel G. Bombolakis } & \text { Boston College } & \text { U.S.A. } \\ \text { Timothy O'Connor } & \text { Boston College } & \text { U.S.A. } \\ \text { Eugene Szymanski } & \text { Boston College } & \text { U.S.A. } \\ \text { Eileen Vergino } & \text { Lawrence Livermore National Laboratory } & \text { U.S.A. } \\ \text { Jean Savy } & \text { Lawrence Livermore National Laboratory } & \text { U.S.A. } \\ \text { William Foxall } & \text { Lawrence Livermore National Laboratory } & \text { U.S.A. } \\ \text { Larry Hutchings } & \text { Lawrence Livermore National Laboratory } & \text { U.S.A. } \\ \text { Rengin Gok } & \text { Lawrence Livermore National Laboratory } & \text { U.S.A. } \\ \text { Randolph Martin } & \text { New England Research } & \text { U.S.A. } \\ \text { Mary Krasovec } & \text { New England Research } & \text { U.S.A. } \\ \text { Spring Romer } & \text { New England Research } & \text { U.S.A. } \\ \text { Nathan Martin } & \text { New England Research } & \text { U.S.A. } \\ \text { M. Nafi Toksoz } & \text { Massachusetts Institute of Technology } & \text { U.S.A. } \\ \text { Youshun Sun } & \text { Massachusetts Institute of Technology } & \text { U.S.A. } \\ \text { Maggie Benoit } & \text { Massachusetts Institute of Technology } & \text { U.S.A. } \\ \text { Sadi Kuli } & \text { Massachusetts Institute of Technology } & \text { U.S.A. } \\ \text { Levent Gulen } & \text { Massachusetts Institute of Technology } & \text { U.S.A. }\end{array}$

\section{International Collaborators (by affiliation)}

$\begin{array}{lll}\begin{array}{l}\text { Sergey Nazaretyan } \\ \text { Hector Babayan }\end{array} & \text { National Survey for Seismic Protection } & \text { Armenia } \\ \begin{array}{l}\text { Avetis Arakelyan } \\ \text { Reuben Jrbashyan }\end{array} & \text { National Survey for Seismic Protection } & \text { Armenia } \\ \text { Arkadi Karakhanyan } & \text { GEORISK } & \text { Armenia } \\ \text { Reuben Gevorkyan } & \text { Inst. of Mechanics of the National Academy of Sciences } & \text { Armenia } \\ \text { Simon Papyan } & \text { Armenian Association of Seismology and Physics of the Earth's } & \text { Armenia } \\ & \text { Interior } & \text { Armenia } \\ \text { Behrouz Panahi } & \text { Geology Institute, Azerbaijan National Academy of Sciences } & \text { Azerbaijan } \\ \text { Tahir Mamedov } & \text { Republic Center of Seismic Survey of ANAS } & \text { Azerbaijan } \\ \text { Fuad Aliyev } & \text { Republican Center of Seis. Survey, National Academy of Sciences } & \text { Azerbaijan } \\ \text { Shota Adamia } & \text { Georgian Geological Service Center "GEOECO" } & \text { Georgia } \\ \text { Zurab Javahishvili } & \text { Seismic Monitoring Center } & \text { Georgia } \\ \text { Mikhael Elashvili } & \text { Seismic Monitoring Center } & \text { Georgia } \\ \text { Tea Godoladze } & \text { Seismic Monitoring Center } & \text { Georgia } \\ \text { Cemil Gurbuz } & \text { Kandilli Observatory and Earthquake Research Institute } & \text { Turkey }\end{array}$

*More information on the project is available at the CauSIN website: www.causin.org 


\section{Chapter 1: Introduction}

\subsection{Project Background}

The Caucus is a region of active tectonics and complex crustal structure located between the Caspian Sea to the east and the Black Sea to the west. To the north is the aseismic Eurasian shield, and to the southwest and the south are the active tectonic regions of East Anatolia and the Zagros thrust and fold belt of northwestern Iran. (Figure 1-1) The major tectonic features of the region were formed by the collision of the Arabian Plate with Eurasia about 12 million years ago (Dewey et al. 1986; Sengör and Kidd 1979). This collision and the continuing northward motion of the Arabian Plate are responsible for the indentation of the Bitlis Suture and the westward escape of the Anatolian Plate bounded by the North and East Anatolian Faults, and the dense deformation of the East Anatolian Plateau (Dercourt et al. 1986; McKenzie 1972; Jackson and McKenzie 1988; McClusky et al. 2000). The Eurasian collision was also responsible for the formation of the Caucasus (Phillip et al. 1989).

While the region is seismically active (Figure 1-5), most of the crustal models and earthquake locations are based on fieldwork and seismic studies of the Soviet era. Recently, technical advances have continued in the former Republics. Before 2000, the only digital instrumentation in the region was an IRIS station located in Garni, Armenia; now there are new regional networks in Georgia, Armenia, and Azerbaijan. Since this region is of vital interest to the U.S., there was considerable interest in examining the 
tectonics and fault structure of the region in more detail and in obtaining seismic data to develop crustal models and improve our ability to accurately locate events.

Over the past ten years, scientists from New England Research, Inc. (NER), Boston College (BC), Massachusetts Institute of Technology (MIT), and the Lawrence Livermore National Laboratories (LLNL) had been working in the Caucasus to promote international cooperation and examine seismic data which was previously unpublished and unavailable to scientists in the West. To further this effort, a broad based regional program was initiated with scientists from Georgia, Azerbaijan, Armenia, and the United States. Funding was secured through the International Science of Technology Center Moscow (ISTC), the Civilian Research and Development Foundation (CRDF), and the Department of Energy to support this initiative. The project was named the Caucasus Seismic Initiative (CauSIN) and covered the area from $38 \mathrm{E}$ to $5 \mathrm{E}$ longitude and $36 \mathrm{~N}$ to $45 \mathrm{~N}$ latitude.

The CauSIN project consists of three tasks interrelated tasks:

1. Develop a database of geology and active tectonics.

2. Develop a catalog of historical and recent regional earthquakes of magnitude 5 or greater. Improve earthquake locations and identify potential "ground truth" (GT) events.

3. Obtain a detailed crust/upper mantle structure in the Caucasus, eastern Turkey, and northwestern Iran, using data from newly installed seismic stations as well as IRIS and other stations operated as part of the national networks. 


\subsection{Project Results}

\subsubsection{Geology}

There were a number of successful milestones achieved during the project. One was the first digital geologic map for the Republic of Georgia. Our objective was to provide an integrated geologic map, on a scale 1:500,000 for the countries of Armenia, Azerbaijan, and Georgia. All the countries agreed to the geological terminology and the continuation of lithologies across political boundaries. Then work on an integrated map began. The Georgian map is complete; the Armenian effort is nearly completed and will soon be integrated with the map for Georgia. The geological map for Azerbaijan requires additional work. However, there is strong cooperation in the region and they are committed to producing an integrated geologic map. The geology map of Georgia is too large to include in this document; it is attached to this report on cd-rom as referenced in Appendix A.

\subsubsection{Tectonics}

The identification of fault zones and the active seismicity associated with them is an important part of distinguishing clandestine explosions from earthquakes. For this reason, several workshops were held throughout the course of the project in Georgia, Armenia, Istanbul, Turkey, and the United States to work out the details of the fault geometry. The resulting integrated tectonic map of the region, shown in Figure 1-3, is a major contribution of CauSIN project. The tectonics of the region will be discussed in more detail in Chapter Two of this report. 
During these workshops, a controversy developed over the existence of the Borjomi-Kazbegi Fault Zone (BKFZ), a left-lateral strike-slip fault which is a major feature of many tectonic models of the Caucasus, such as that in Figure 1-2. The proposed BKFZ extends from eastern Turkey through the Lesser and Greater Caucasus in Georgia and north into Russia. Although there is strong physical evidence for the fault in eastern Turkey, the evidence of its extension into Georgia is controversial.

Georgian geophysics report little evidence for recent faulting on the BKFZ. However, few detailed studies have been conducted to address the issue. Since many of recent earthquakes, particularly in Iran, have occurred on hidden faults, it is essential to determine whether or not the proposed Borjomi-Kazbegi fault zone actually exists or the extension of the fault zone from Turkey into Georgia is truncated by some other feature.

Therefore, geoscientists from NER and BC have carried out a series of geological and geophysical investigations along the proposed trace of the fault. The field investigations showed no evidence of displacement along the proposed fault zone; this suggests that our interpretation of the tectonics in the Caucasus needs to be revisited. A more detailed discussion of the fieldwork is presented in Chapter Three of this report.

\subsubsection{Seismic Data}

At the beginning of the CauSIN project, there was only digital status in providing information for the greater Caucasus region (an IRIS station at Garni, Armenia). As of now, regional networks are operating in all three Caucasus countries. There is a fourteenstation digital array in Azerbaijan and nine stations operating in Georgia with several more planned. All of the stations in Azerbaijan and most of the stations in Georgia 
telemeter readings to central locations in Baku and Tbilisi, respectively. Armenia is engaged in a joint project with Georgia which aims to upgrade its analog stations to digital, and is pursuing other means of increasing the number of digital stations currently available.

Appendix A contains a summary of the seismic data which has been collected during this project. Our goal was to collect data on all earthquakes in the region greater than magnitude 5. In the era prior to 1991, we have a number of historical records; most are paper records. Many have hand-picked phase arrivals, and some are being digitized where the data quality is high. In the post-Soviet era, there was very little data available. Most of the networks were operated by the Soviets and data acquisition essentially ceased after the 1991 collapse. During the late 1990s, seismic stations were gradually brought back online and new stations were added. Now, in the post-2000 era, the Caucasus nations are beginning to contribute significantly to their digital networks and are continuing to install their own digital-regional networks. Figure 1-4 shows station distribution in the region. These recent data have been used for our 3-D crustal interpretation.

Figure 1-5 shows events in the phase arrival time pick dataset which was used for crustal tomography studies in later parts of this report.

Another contribution of this project is a secure website (www.causin.org) which will used to exchange data amongst participants. The site uses an ArcMAP server to run an interactive mapping utility to display the contents of the CauSIN database, including geological, tectonic, seismic, and geophysical data. 


\subsubsection{Crustal Model}

We have carried out a number of velocity inversions to determine the crustal structure and 3-D crustal tomography for the region using phase-time pick data. The resulting models provide interesting results and provide constraints on a new tectonic interpretation in the region. The tomography technique, the data employed, and the results are discussed in Chapter 4 of this report.

Pn velocities obtained from travel time tomography are shown in Figure 1-6. Pn velocities are lower than average $(7.9 \mathrm{~km} / \mathrm{s})$ under the Lesser Caucasus, eastern Turkey, and under the Greater Caucasus. Pn velocities are higher than average under the eastern Black Sea and the southern Caspian Basin. The velocities are also high under the Rioni and Kura Basins, extending southeast from the Black Sea to the Caspian. These basins and the connecting region separate the Lesser Caucasus from the Greater Caucasus. 


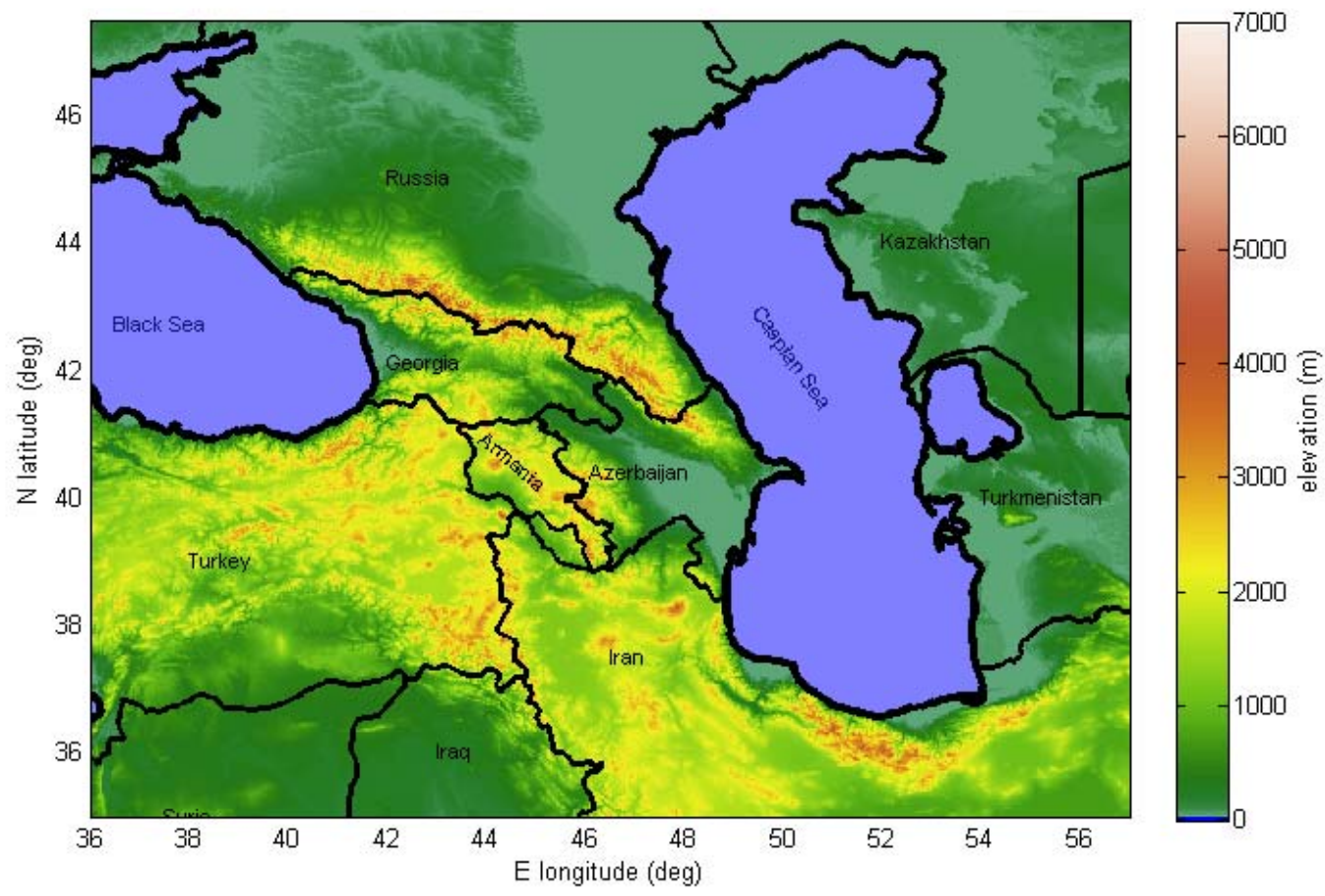

Figure 1-1: The Caucasus region includes Georgia, Armenia, and Azerbaijan between Russian to the north and Iran and Turkey to the south. 


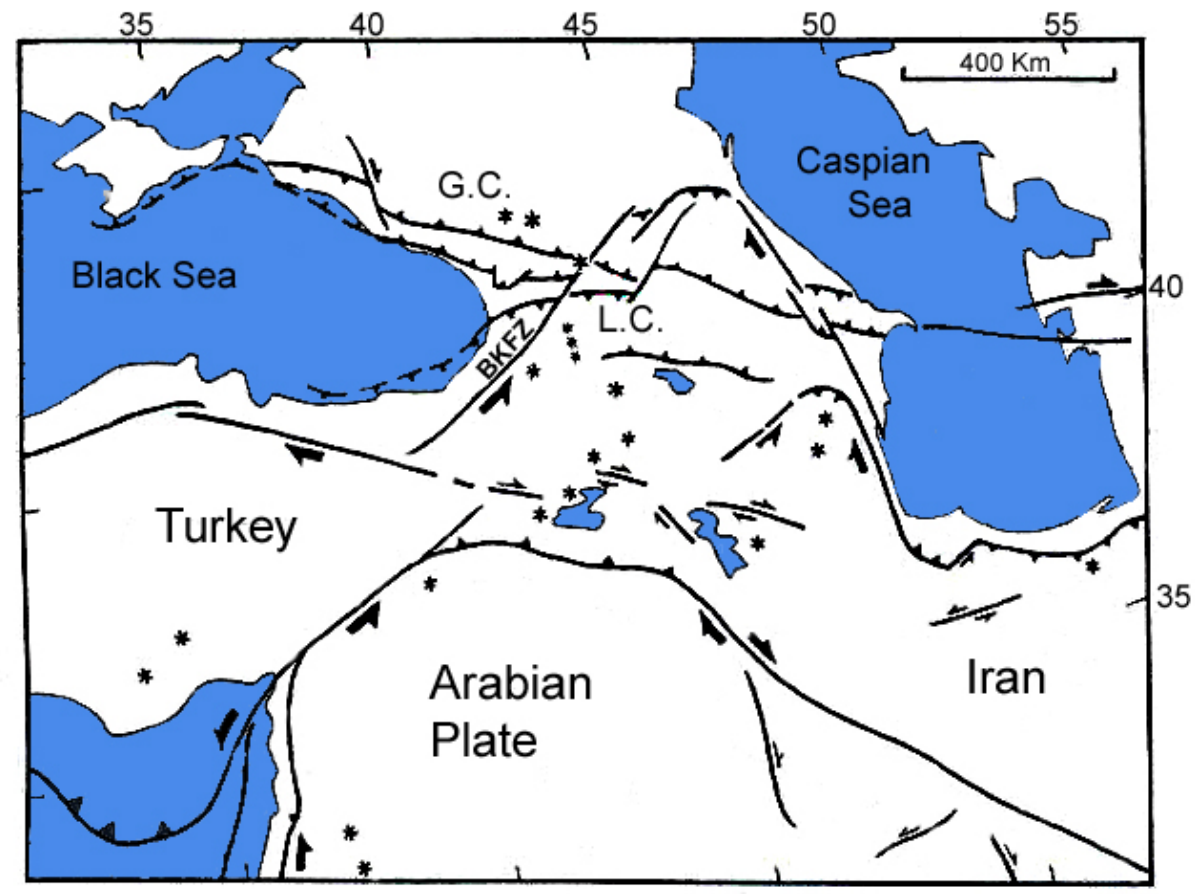

Figure 1-2: Tectonic Model of the Caucasus (after Philip et al. 1989). Note the indenting wedge between the Black and Caspian Seas caused by the northerly migration of the Arabian Plate. The proposed BKFZ is the western boundary of this indenting wedge. The * symbol denotes areas of volcanism. 


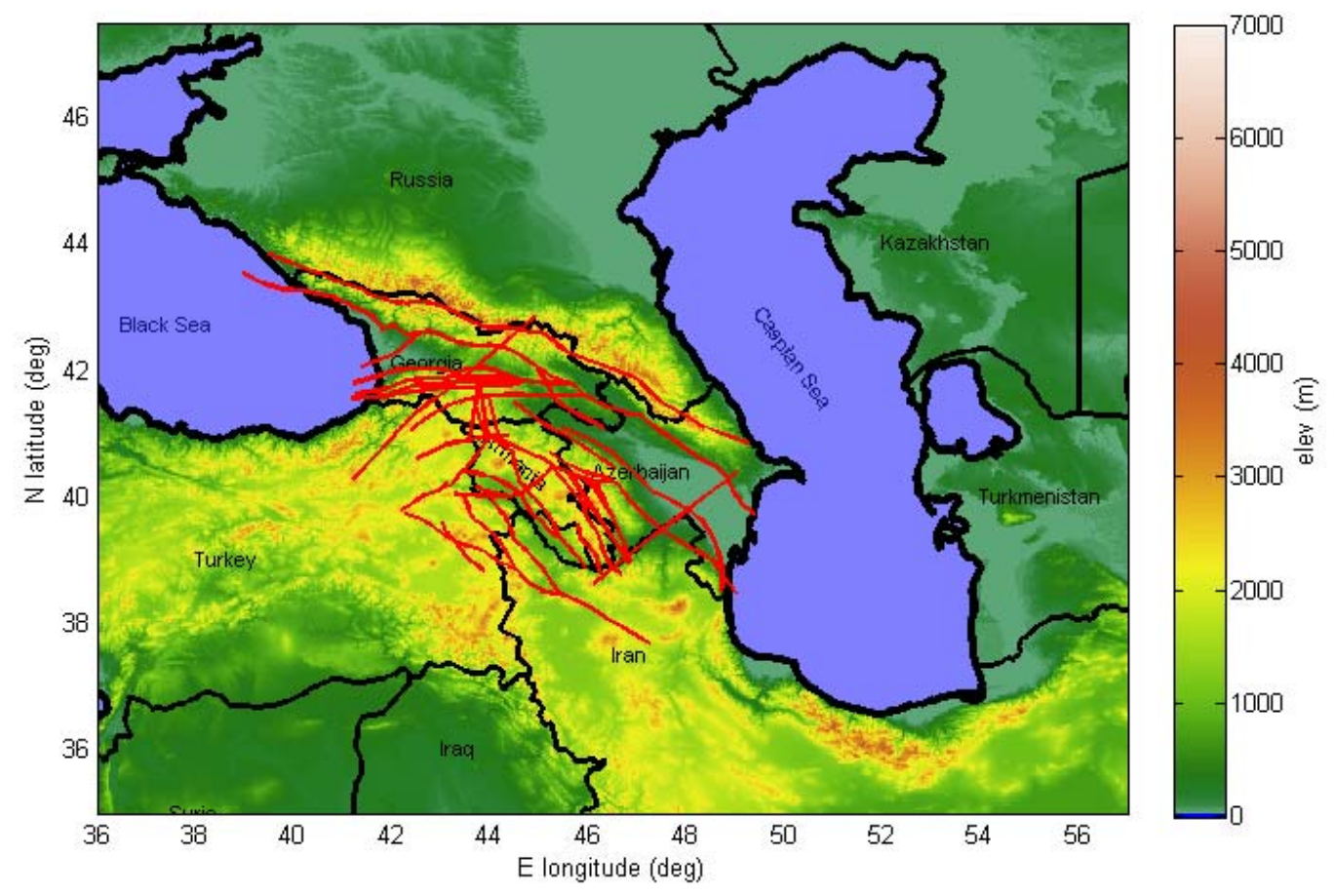

Figure 1-3: The region-wide tectonic model of Caucasus developed by scientists in the region. The SW-NE trending Borjomi-Kazbegi fault zone (BKFZ) is marked with a black arrow. There is ample evidence of its existence in Eastern Turkey, but some believe that it is truncated in the Lesser Caucasus and does not extend north into Georgia. 


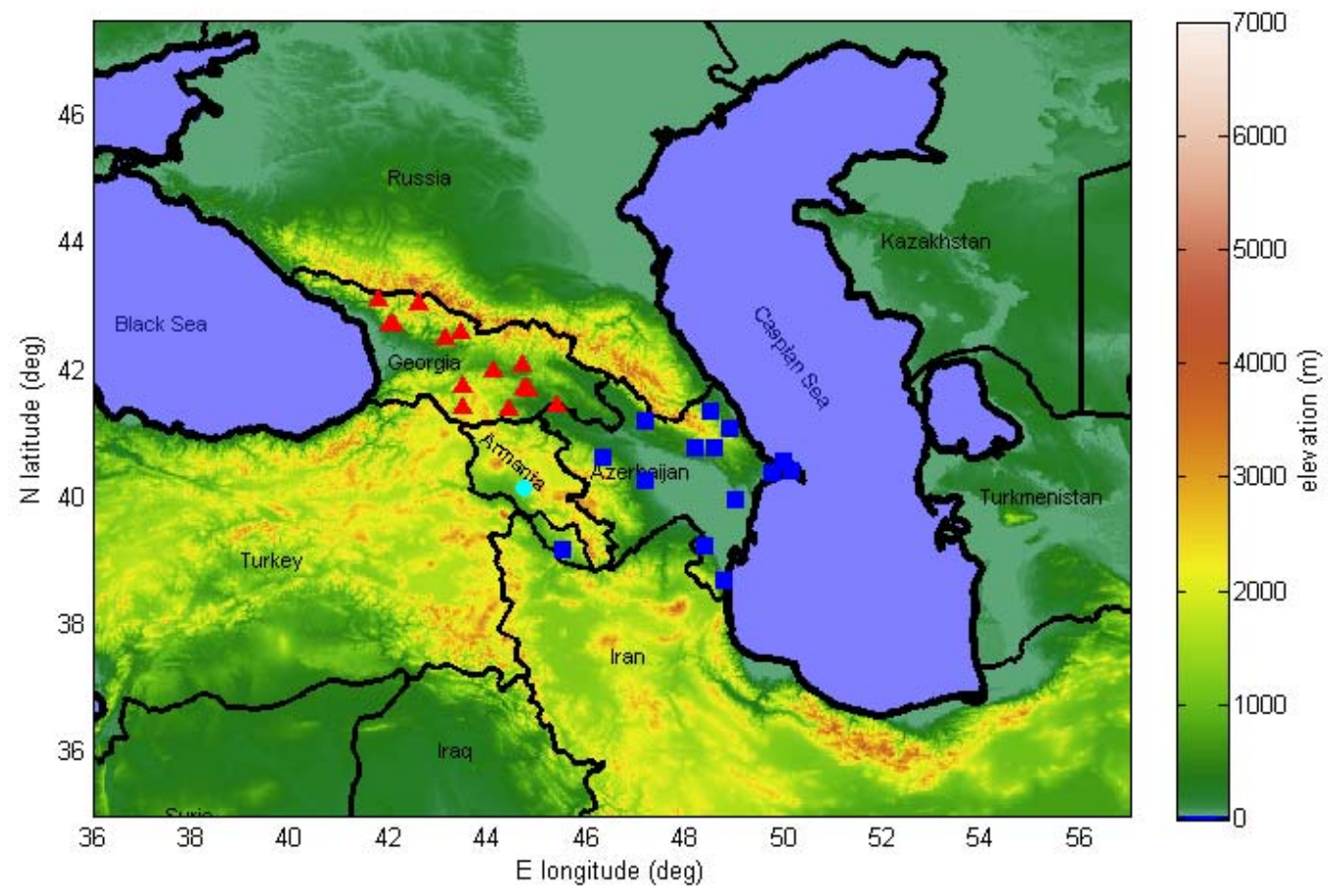

Figure 1-4: Digital stations in Georgia (red triangles), Azerbaijan (blue squares), and Armenia (cyan circle). 


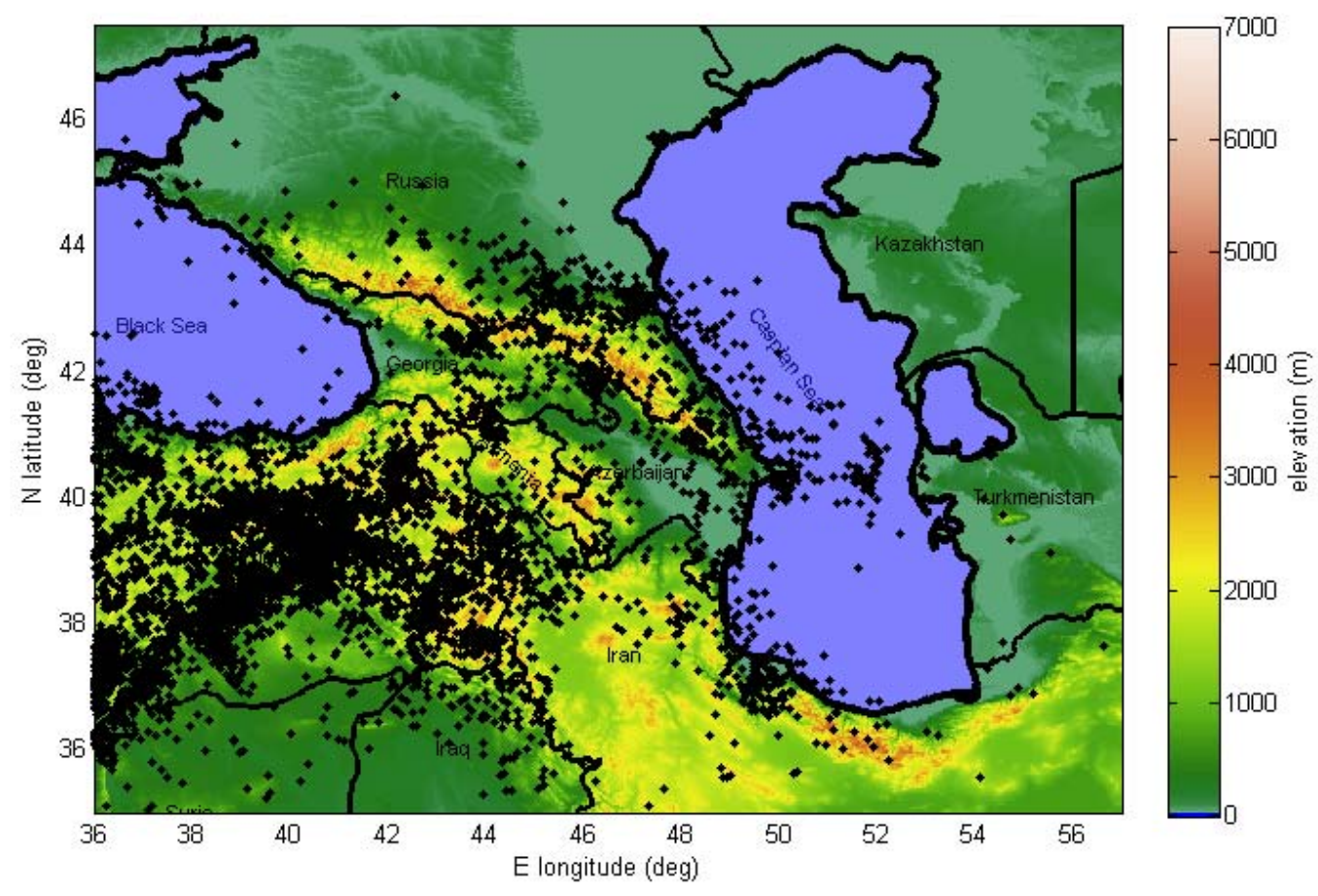

Figure 1-5: Stations and events in the phase pick database used for 3-D crustal tomography studies of the region. 


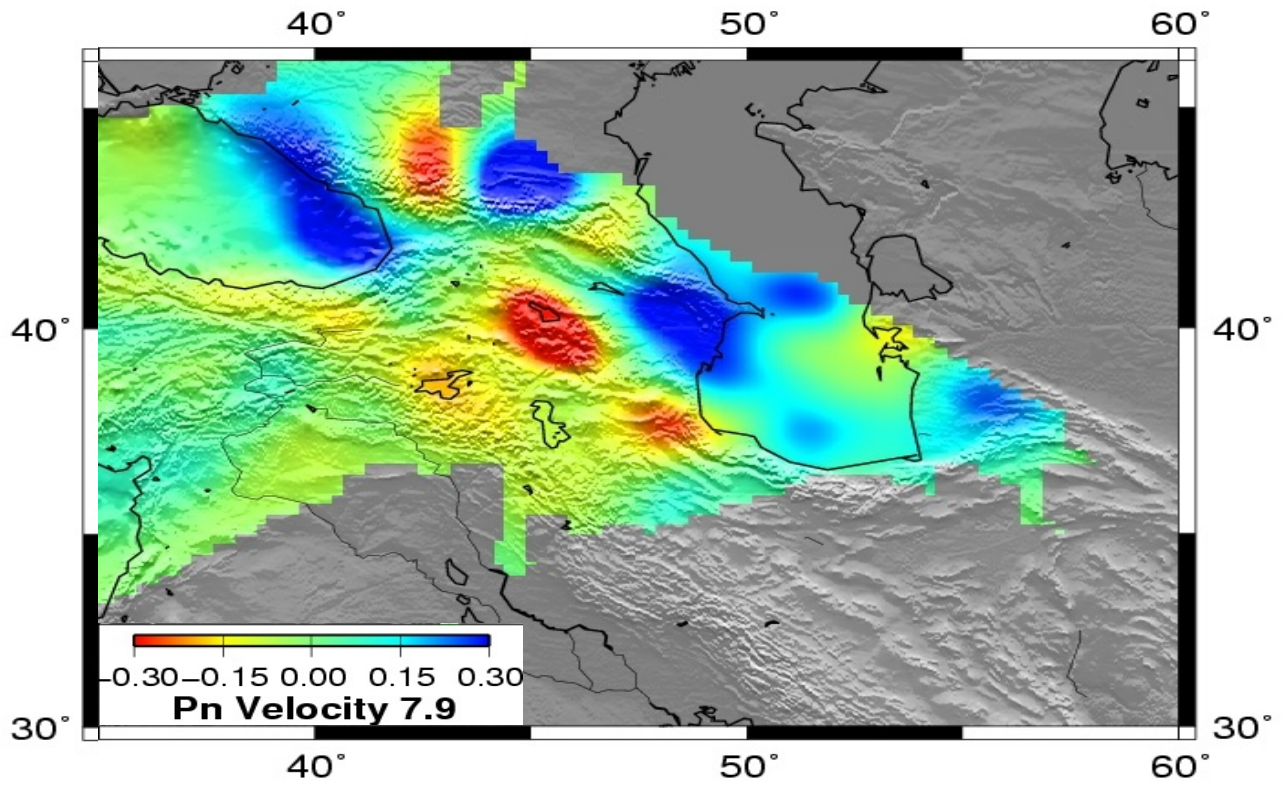

Figure 1-6: Imaged Pn velocity lateral variations. Average Pn velocity is $7.9 \mathrm{~km} / \mathrm{s}$ and variation corresponds with color, red represents lower velocity than the average and blue denotes higher velocity 


\title{
Chapter 2: Tectonics of the Caucasus and Border Regions: Some Major Features and Problems
}

\begin{abstract}
The following summary focuses on several tectonic features and problems of a complex major segment of the Alpine-Himalayan Belt, the segment that extends from the Caucasus and South Caspian Sea southward across the East Anatolian-Iranian Plateau, down into the collision zone with the Arabian plate.

This segment has become of prime political and scientific importance in recent years. Several of its principal features to be discussed are (1) the Bitlis-Zagros suture zone of continental-continental collision between the Arabian and Eurasian plates, (2) some basic problems and tectonics in the Zagros and Caucasus regions, (3) the question of whether subduction is being initiated beneath the South Caspian Basin, (4) some peculiar features of the seismically active Alborz and Talysh mountain belts that appear to wrap around the south and southwest border of the South Caspian Basin, and (5) tectonic implications of seismic-wave attenuation observed in the Turkish-Iranian Plateau.

Included in this summary are published results of our collaboration with Georgian colleagues at the Dept. of Geology and Paleontology, Tbilisi State University, and the Geological Institute of the Georgian Academy of Sciences. Figure 2-1 shows the area of interest for the Caucasus project, including the fault segments agreed upon by the organizations of interest.
\end{abstract}




\subsection{Introduction and Background}

The origin and development of the Turkish - Iranian Plateau are critical for a better understanding of the neotectonics of the Caucasus and adjacent regions. This is because this plateau is such an extensive intervening portion of the roughly $3,000,000$ square kilometers undergoing deformation by the Arabia - Eurasia continental collision. It also is one of the two main plateaus of the Alpine - Himalayan chain of continental collisions, the other being the Tibetan Plateau. Very few publications have focused on the neotectonics of the Turkish - Iranian Plateau and its relation to the Caucasus region. We present here a more in-depth analysis.

New seismotectonic information is becoming available from several local digital seismic networks located in strategic parts of the region, and so descriptions of them and their results are incorporated in our analysis. Some topics, such as the North Anatolian fault zone, are treated in greater detail because they involve concepts that can be utilized for attacking related problems in the Caucasus; e.g., the proposed Borjomi-Kazbegi crustal fault that is inferred to cut across the entire Caucasus; and estimates of seismic potential, seismic moment, and seismic attenuation. Also, perhaps knowledge of how mistakes of interpretation were made in past studies can help avoid repeating them again.

\subsection{Continental Collision, the Bitlis-Zagros Suture zone, and the Zagros}

Figure 2-2 illustrates a schematic stage of continental collision between the Anatolian microplate and the Arabian and Eurasian plates. This continental collision usually is considered to be one of the youngest on Earth, initiated only 10-12 million years ago (e.g., Sandvol et al, 2003). However, Hempton $(1985,1987)$ has presented 
evidence that initial suturing began near the west end of the Bitlis suture shown in Fig. 22, around the mid-late Eocene, 45-36 million years ago. It pre-dated the opening of the Red Sea and the development of the Dead Sea Transform Fault (DSF in Fig. 2-2). Lateral closure apparently progressed gradually, completing the length of the Bitlis suture in Fig. 2-2, almost 5 million years ago.

Dewey et al (1986) interpreted the East Anatolian plateau as undergoing a thickening to $52 \mathrm{~km}$, beginning in the Medial Miocene, transmitting deformation to surrounding regions; e.g., the Lesser Caucasus. As will be seen, re-interpretation here is necessary. For example, the modern Caucasus extends ESE in Fig. 2-2 from the Black Sea to the Caspian Sea. A huge amount of stratigraphic data, mostly not published in the western literature, has been collected in the Caucasus over many years particularly by the Georgians. These data contain the first stratigraphic evidence of a relatively late stage of Tethys subduction critical for the Caucasus' subsequent growth. This stage began at the turn between latest Eocene and Oligocene, about 37-38 million years ago, when single Ocean Tethys was transformed into enclosed and semi-enclosed sea basins of Para Tethys. Shallowing of these basins began gradually. Then, dramatically, a complete inversion of these basins, with the formation of the Greater and Lesser Caucasus, began in late Miocene time, 10-12 million years ago, with inversion proceeding at a higher rate (not less than $1.6 \mathrm{~mm} / \mathrm{yr}$ average) during Pliocene-Quaternary times. The amount of vertical displacement of relevant key marker beds, measured with respect to their subsidence and uplift, is approximately $10 \mathrm{~km}$ (Adamia et al, 2002a; 2002b).

The front of the Zagros fold belt in Fig. 2-2 extends over the Arabian platform. This belt also is considered to be young (Pliocene). Jackson and McKenzie (1984; 1988) 
and their colleagues (e.g., Berberian, 1995) interpret the Zagros to be an active basementinvolved fold-and-thrust belt undergoing possibly $20 \mathrm{~mm} / \mathrm{yr}$ NE shortening, modified by local zones of strike-slip faulting, such as the Main Recent Fault, located along the NW portion of the Zagros suture in Fig. 2-2. Many of their well-constrained focal mechanisms are interpreted to occur on reverse and thrust faults dipping $40^{\circ}-50^{\circ} \mathrm{NE}$ within the continental basement at 8-12 km depth, with no hypocenters detected deeper than $20 \mathrm{~km}$. Deformation of the sedimentary cover, ranging in thickness from some 6 to $15 \mathrm{~km}$, appears to be predominantly aseismic above the Lower Cambrian Hormuz salt horizon. Spectacular fold trains are presumably detached from the underlying Hormuz Salt and other salt horizons. Recent balanced cross sections across the Zagros, however, have been interpreted to indicate that the earthquakes described above might be originating in some of the sedimentary strata above the Hormuz (McQuarrie, 2004).

A major problem here is the rarity of exposed thrusts, deep wells, and published seismic sections across the Zagros fold belt. This makes structural and tectonic interpretation difficult (e.g., Blanc et al, 2003). As a result, the correlation of specific earthquakes with specific faults is questionable in most cases (Berberian, 1995). To partially circumvent these difficulties, Berberian has utilized a wealth of supplementary data for many years in his analyses of the Zagros. He and most students of the Zagros identify the Zagros suture in Fig. 2-2 with a major regional fault, the Main Zagros Reverse Fault. If this is correct, it helps cement a Pliocene age to the Zagros. But a potentially critical factor in this case is whether a parallel complexly deformed belt, the Sanandaj-Sirjan Belt, on the NE side of the designated suture in Fig. 2-2, is an integral part of the Zagros, as maintained by Alavi (1994). If so, then the Zagros suture would lie 
further NE in Iran, possibly between the Sanandaj-Sirjan belt and the remnants of a parallel interpretive magmatic arc, the Urumiah-Dokhtar Arc, an Andean type arc of possibly Upper Cretaceous age.

\subsection{The Caucasus Region}

Figure 2-3, adapted from Philip et al (1989), shows some of the tectonic and geologic features of the Caucasus region. The Russian Platform (Scythian Platform) lies north of the Greater Caucasus (G.C.). Both the Black Sea and the southern portion of the Caspian Sea (the South Caspian Sea) have been interpreted frequently as remnants of back-arc basins with oceanic crust, a problem that still needs to be resolved. Between the Black and South Caspian Seas, the Caucasus from north to south consists of three parts: the Greater Caucasus (G.C.), the Transcaucasus which includes intermountain basins denoted by dotted symbol \#7, and the Lesser Caucasus that extends further WSW than shown in Fig. 2-3.

\subsubsection{South Caspian Subduction Hypothesis}

The South Caspian Basin is a $300 \mathrm{~km} \times 300 \mathrm{~km}$ aseismic block containing 13 to $25 \mathrm{~km}$ thickness of sediments, one of the deepest basins known. The oldest sediments in it are thought to be Paleocene or older (Berberian, 1983). It is surrounded by relatively narrow belts of earthquake activity: the Talysh thrust zone on the west ( $\mathrm{T}$ in Fig. 2-3), the Alborz Mtn. Belt on the South (Al. in Fig. 2-3), the Kopeh-Dag belt (not shown) at the ENE juncture with the Alborz, and the so-called "Apsheron Sill" on the north (A.S.) 
Figure 2-4 from Jackson (2001) shows a remarkable velocity field of averaged active deformation extending NNE from the Zagros towards the Caspian Sea. This velocity field is an important feature for analysis of the South Caspian Basin; the technique employed in Fig. 2-4 describes the average or long-wavelength deformation in which the wavelength is appreciably larger than the thickness of the upper crustal seismogenic zone. Consequently, it is necessary to supplement Fig. 2-4 with relevant details of deformation of the belts that border the South Caspian Basin in Fig. 2-3, and with additional seismic data.

Most of the earthquakes in those belts, some with MS $>6$, have centroid depths less than $15 \mathrm{~km}$ (Jackson et al, 2002). None deeper than $30 \mathrm{~km}$ have been detected, except along the Apsheron Sill and to the north of it in the middle Caspian region. There, centroid depths range from $30 \mathrm{~km}$ to about $100 \mathrm{~km}$. The predominant focal mechanisms along the Sill are nearly parallel normal fault mechanisms at $30-50 \mathrm{~km}$ depths, some with MW $>6$. These data, and the velocity field in Fig. 2-4(b), lead to the hypothesis that initial subduction of the South Caspian lithosphere might be occurring northeasterly beneath the middle Caspian region, with bending of the lithosphere beneath the Apsheron Sill.

One crustal model of the South Caspian Basin, reviewed by Gagelgantz et al. (1958), Aronov et al. (1961), Krugliakov and Krugliakova (1975), Jackson et al (2002), is based on receiver functions, surface wave analyses, and published seismic refraction studies. It reveals that "granitic crust" $\left(\mathrm{V}_{\mathrm{p}}=5.8-6.5 \mathrm{~km} / \mathrm{sec}\right)$ on the south, east, and west sides of the basin is absent within the South Caspian Basin. A "basaltic crust" $\left(\mathrm{V}_{\mathrm{p}}=7.1\right.$ 
$\mathrm{km} / \mathrm{sec}$ ) is irregular in thickness, with an arc-shaped Moho at an average depth of $30-35$ $\mathrm{km}$.

The S-wave velocity in the mantle lid agrees with the observed Sn velocity of about $4.7 \mathrm{~km} / \mathrm{sec}$ across the basin, as reported by Kadinsky-Cade et al (1981). Efficient Sn propagation and blockage of $\mathrm{Lg}$ across the South Caspian Basin are consistent with the presence of oceanic crust, but Lg blockage is not reliably diagnostic because the structure of a large deep basin can block Lg waves (Formuru and Kennett, 1997). The tomography results in Chapter 4 are in general agreement with these findings (the average Pn velocity is $7.9 \mathrm{~km} / \mathrm{s}$, and the average $S n$ velocity is $4.5 \mathrm{~km} / \mathrm{s}$ ).

The Alborz Mountain Belt (Al. in Fig. 2-3) exhibits very peculiar features. It seems to wrap around the southern border of the South Caspian Basin, with peaks as high as 3.6 to $4.8 \mathrm{~km}$ and a width of only $60-120 \mathrm{~km}$; a steep mountain belt. Receiver function analyses indicate that the Alborz has a 35 - km thick crust (Jackson, el al, 2002). The Alborz also reportedly has no root, but is calculated to have undergone $10 \mathrm{~km}$ uplift beginning $4-6$ million years ago (Axen et al, 2001), nearly synchronous with a period of rapid subsidence within the South Caspian Basin, during which almost half of the $20 \mathrm{~km}$ sediment thickness was deposited during the Pliocene, presumably after the construction of the Turkish - Iranian Plateau. The eroded Alborz now exhibits a sequence of Late Precambrian strata to Eocene sedimentary and volcanic strata. They are locally intruded by plutons and dikes, such as the Alan Kuh granite pluton emplaced only 7 million years ago.

The highest peak in the Alborz is the enigmatic Damavand stratovolcano. It is located northeast of Tehran at an elevation of about $5.67 \mathrm{~km}$ above sea level. It is the 
highest peak in the Middle East. Volcanism at Damavand reportedly began ca. 1.8 million years ago, but is currently dormant with no eruptions during the past thousand years. No suture associated with it has been found (Davidson et al, 2004).

There is definitely no evidence from earthquake depths that subduction is occurring beneath the Alborz. All of the well-constrained hypocenters are less than 15 $\mathrm{km}$ depth. Most focal mechanisms consist of reverse faults and left-lateral faulting, notably the 1990 MW 7.3 Rudbar-Tarom left-lateral strike-slip event in the western Alborz (Berberian et al, 1992). The overall motion within the Alborz currently seems to involve oblique left-lateral shortening.

The Talysh belt ( $\mathrm{T}$ in Fig. 2-3) at first glance seems to be a continuation of the Alborz. It is actually a thrust belt ranging $\mathrm{N}-\mathrm{S}$, bordering the west coast of the South Caspian in Iran and Azerbaijan. Further north, it swings into an E - W trend where it meets the flat plains of the Kura intermountain basin. Jackson et al (2002) report that the Talysh contains many of the same rocks as the Alborz, including a thick Paleogene volcaniclastic sequence with folds approximately parallel to the trend of the range. However, the Talysh exhibits earthquakes quite different from the Alborz. They involve low - angle thrust events, estimated to be MW $>5.3$, with slip vectors oriented easterly towards the South Caspian Sea, at depths of $15-26 \mathrm{~km}$, deeper than most seismic events in the Alborz.

\subsubsection{The Greater and Lesser Caucasus}

A major requisite for deciphering Caucasus tectonics is evaluation of the reliability of available data. Plate tectonic models indicate that the circuit closure rate of 
the Arabian plate is northerly, possibly NNW, in the range of $25-35 \mathrm{~mm} / \mathrm{yr}$, a rate averaged over the past few million years, whereas the comparable average rate of the African plate is northerly at about $10 \mathrm{~mm} / \mathrm{yr}$. GPS data for Arabia currently are available from only a few sites on the northern Arabian platform. The average rate of motion there, averaged over a ten-year period, is $16-20 \mathrm{~mm} / \mathrm{yr}$ in a direction $\mathrm{N} 20^{\circ}-30^{\circ} \mathrm{W}$ (McClusky et al, 2000).

GPS data also are available currently for portions of the Caucasus region. These data indicate that velocities of motion are very small for the continental crust a short distance north of the Greater Caucasus, whereas GPS data on the south side indicate that underthrusting might be occurring beneath the southern slope of the Greater Caucasus. This possibility is considered as follows.

In Fig. 2-5, The Greater Caucasus extends more than $1200 \mathrm{~km}$ ESE from the northern zone of the eastern Black Sea towards the Caspian Sea. The locations of two cross sections also are shown: section II in the west and section 5(b) in the east. Section II is indicated by the arrows extending from point II, SSW across the Russian Platform, through Mt. Elbrus (E), and then crossing "The Main Thrust" on the southern slope of the Greater Caucasus, before terminating in the Rioni Basin (R.B.).

The Main Thrust is denoted in Fig. 2-6 by the circled number 16. This cross section is one of three constructed by Dotuev (1986) to illustrate the structure of the western half of the Greater Caucasus. The Main Thrust is interpreted to be a major thrust zone dipping northerly beneath the southern slope and penetrating the Scythian Plate (Russian Platform), with horizontal tectonic displacements of $200 \mathrm{~km}$. Several former Soviet geoscientists considered this thrust zone to be part of a Benioff zone demarcated 
by a group of earthquakes with deep hypocenters further north. These hypocentral depths, however, are considered unreliable by Jackson and McKenzie (1984). Moreover, Dotuev (1986) emphasized that his cross sections are strictly hypothetical, and require testing by deep drilling and geophysical techniques. They still need to be tested.

A major earthquake, the April 29, 1991 MS 7.0 Racha earthquake occurred east of section II in Fig. 2-5, not far west of the Kazbeg Volcano (K). It occurred along a blind fault; viz., a fault that did not penetrate the topographic surface. The mainshock focal mechanism apparently was a thrust dipping NE beneath the Greater Caucasus. It buried at least one village on the southern slope with landslide rock debris. The aftershock zone was $10-25 \mathrm{~km}$ wide and more than $70 \mathrm{~km}$ in length, interpreted to lie beneath the southern slope (Triep et al, 1995).

Mt. Elbrus, in Russia, is the highest peak in the Greater Caucasus. It was climbed by German mountain troops during their World War II campaign in the Caucasus, angering Hitler as a crazy lark during warfare. The elevation of Mt. Elbrus (E) approaches $5.67 \mathrm{~km}$, nearly as high as the enigmatic Damavand volcano in the Alborz. Like the Damavand, Mt. Elbrus is an enigmatic stratovolcano. It also was last active within the last few thousand years. Superficially it appears to be part of a volcanic chain or arc extending ESE in Fig. 2-5 to the Kazbeg volcano (K), one of the highest peaks in Georgia. But this chain does not extend further ESE along the Greater Caucasus. It appears to be cut off mysteriously by the Borjomi-Kazbegi Fault (B-K) in Figures 2-1, 3 and 5. This fault was proposed by Milanovsky $(1968,1977)$, Philip et al (1989) to be a major crustal transform fault that extends further SW, joining the Anatolian system of major faults. State Geological mapping (Adamia, personal communication, 2004) and 
GPS data, however, do not support their interpretation of B-K (McClusky et al, 2000). This conclusion is supported by detailed field studies $(2005$ - 2006) as discussed in Chapter 3.

Jackson (1992) notes that plate motion model, NUVEL-1, predicts a strongly oblique component to the convergence between Arabia and Eurasia at the longitude of the Caucasus, and that earthquake focal mechanisms suggest that the oblique convergence is partitioned into pure right-lateral strike-slip motion in eastern Turkey and pure shortening by thrusting in the Greater Caucasus. Horizontal components of slip vectors in the western half are oriented preferentially north, but are significantly different from slip vectors in the eastern Greater Caucasus. Most available focal mechanisms in the eastern part of the range show low-angle thrusting on planes dipping gently towards the mountains on both sides (Jackson et al, 2002).

Two N-S balanced cross sections of the northern slope of the eastern Greater Caucasus are shown in Fig. 2-7. Evidence based on drilling data, seismic reflection profiles, and mapping indicates that the deformation displayed in these cross-sections occurred during Pliocene-Quaternary time (Sobornov, 1996). The location of Sobornov's cross-section 5(b) is indicated in Fig. 2-5, where it crosses the Dagestan wedge (D). His other cross section, 5(a), is located a little further west of 5(b), beyond the Dagestan wedge. He had the technical advice and assistance of A. Bally and P.B. Jones, two prominent experts on balancing techniques and their application to thrust belts. Consequently, even though balanced cross sections frequently do not provide unique solutions of subsurface structure, the cross sections in Fig. 2-7 are admissible possibilities 
relevant for the eastern Greater Caucasus. The amount of horizontal shortening calculated from those balanced sections is almost $38 \mathrm{~km}$.

The contrast in deformational styles in Fig. 2-7 evidently reflects some contrasts in lithology of the two nearby sections. For example, evaporate horizons, indicated by the basal part of symbol 4, are more prominent in section 5(a) than 5(b). Fig. 2-7 therefore provides a clue that structural styles of deformation might vary considerably over short distances within the Caucasus wherever appropriate contrasts of lithology occur.

\subsubsection{Turkish-Iranian Plateau}

Figure 2-8 illustrates the approximate extent of inefficient Sn propagation in the Lesser Caucasus and the Turkish-Iranian plateau revealed by Kadinsky-Cade et al (1981) and Rodgers et al (1997). This picture has been refined and amplified considerably by the Eastern Turkey Seismic Experiment (ETSE), a 29-station temporary broadband PASSCAL network operated from October 1999 to August 2001, with an average station separation of about $50 \mathrm{~km}$ (Sandvol et al, 2003). For well-recorded shallow events, it was estimated that epicenters could be located within a $3 \mathrm{~km}$ range of error and that hypocenters could be located within a $5 \mathrm{~km}$ range of error. One result is that no seismic evidence could be detected of underthrusting/subduction of the Arabian plate beneath Eurasia. Another result is that the ETSE could record a distinct difference in deformational style east and west of the Karliova triple junction, which is located in the immediate vicinity of the junction of the Anatolian plate with the Arabian plate and Eurasia in Fig. 2-2. 
The ETSE results are consistent with escape tectonics of Anatolia revealed by GPS in Fig. 2-9. An important finding is that the average crustal thickness of the East Anatolian High Plateau is appreciably less than the 52-km thickness predicted by Dewey et al (1986) for compressional thickening and isostatic compensation. The crustal thickness varies from about $42 \mathrm{~km}$ near the Bitlis suture to about $50 \mathrm{~km}$ thickness near the North Anatolian Fault in Fig. 2-2, with an average thickness of about $45 \mathrm{~km}$ and average elevation of $2 \mathrm{~km}$. Seismic data also indicate that segments of the North Anatolian fault zone might extend further SE, well beyond the Karliova triple junction. With respect to Fig. 2-8, $\mathrm{S}_{\mathrm{n}}$ is not observed in eastern Turkey, NW Iran, and central Anatolia, perhaps due to the absence of normal lithospheric mantle or the presence of thin hot mantle beneath most of the Turkish-Iranian plateau. This seems to be consistent with the relatively low-valued Pn velocity anomalies beneath NW Iran, the Caucasus, the Eastern Anatolian High Plateau, and most of the Anatolian microplate, in contrast with the normal lithosphere of the Arabian plate on the south side of the Bitlis suture (the results of our $\mathrm{P}_{\mathrm{n}}$ tomography in Chapter 4 are in agreement). It is to be noted that the area of the inefficient Sn propagation coincides with the territory of Neogene-Quaternary volcanic activities of the region.

An intriguing finding of the ETSE for the Caucasus is that Sn propagation is inefficient in portions of the western greater Caucasus and throughout most of the Lesser Caucasus. A history of neotectonic volcanism exists in the Lesser Caucasus (Adamia et al., 2002a). But it is not clear yet to what extent the concepts derived from the ETSE results apply to the Lesser Caucasus and portions of the Greater Caucasus. Whereas strike-slip faulting is a major mode of deformation in the region of the Turkish-Iranian 
plateau, thrusting and reverse faulting is a major mode of deformation in the Caucasus. For example, many thrusts and reverse faults in portions of the southern slope of the Greater Caucasus and the northern slope of the Lesser Caucasus are directed towards the intervening intermountain basins (Adamia et al, 2000c).

\subsection{Discussion/Conclusions}

Further studies of $S_{n}$ and $P_{n}$ in the Lesser Caucasus and portions of the Greater Caucasus may help determine whether only thin hot mantle lies beneath the Moho, and/or to what extent the tectonics of the Caucasus region can be clarified using these studies.

Acknowledgements: Major contributors to this section include Mike Bombolakis (Boston College), Shota Adamia (Tbilisi State University), Randy Martin (NER), and Spring Romer (NER). 


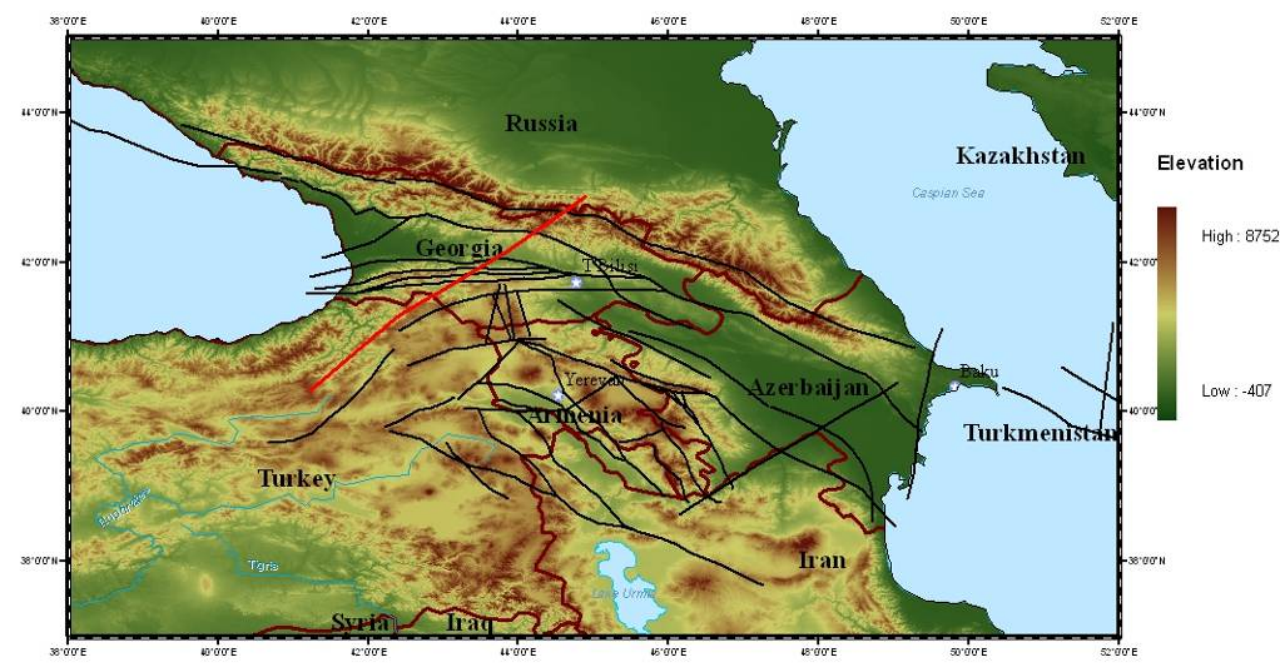

Figure 2-1: The Caucasus region of interest showing the fault segments and highlighting the Borjomi-Kazbeg proposed fault segment (discussed further in this chapter as well as Chapter 3) in red. 


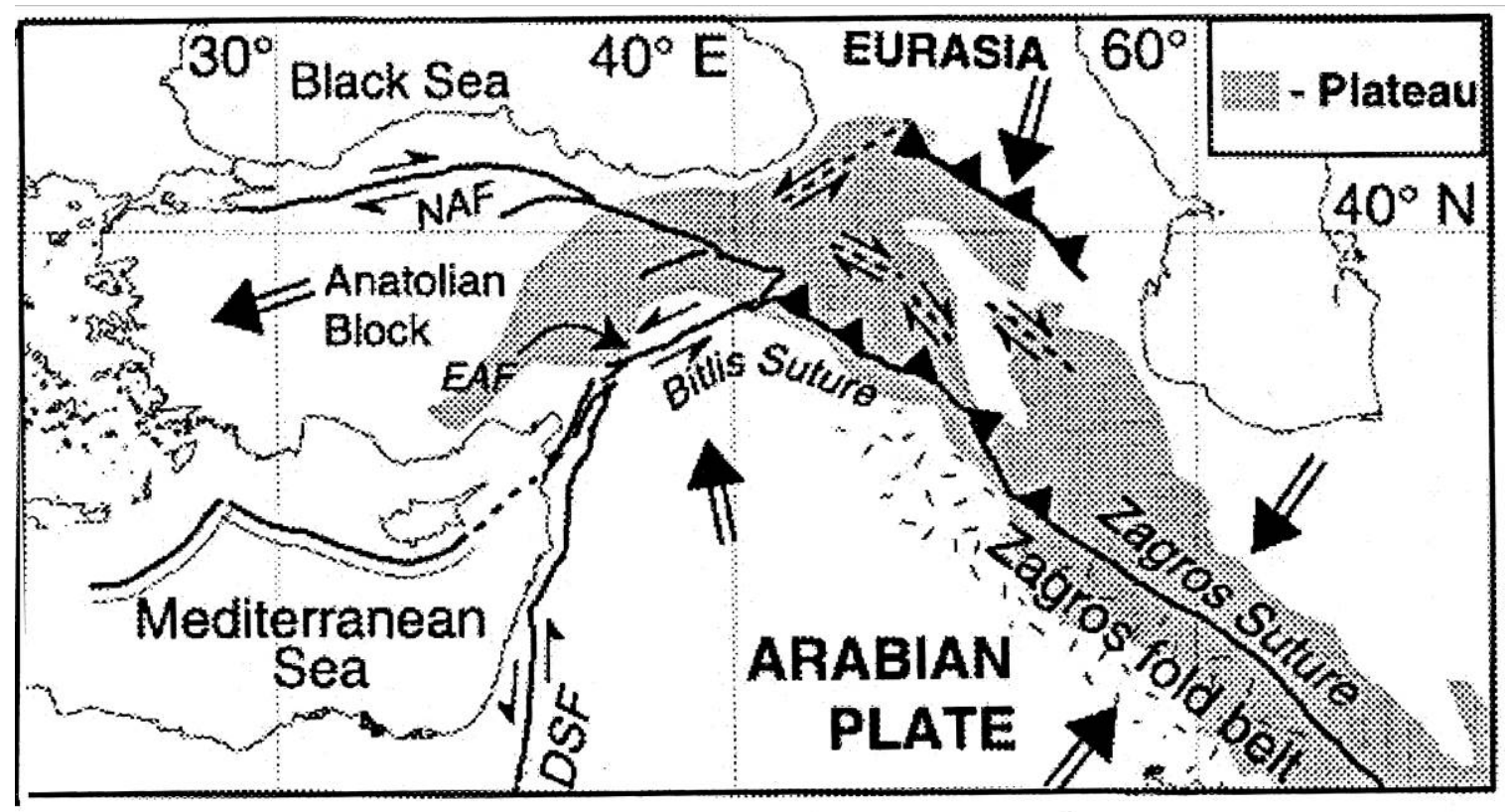

Figure 2-2: Illustrates a schematic stage of continental collision between the Anatolian microplate and the Arabian and Eurasian plates. This continental collision usually is considered to be one of the youngest on Earth, initiated only 10-12 million years ago (e.g., Sandvol et al, 2003). However, Hempton $(1985,1987)$ has presented evidence that initial suturing began near the west end of the Bitlis suture shown in Fig. 2-2 around the mid-late Eocene, 45-36 million years ago. It pre-dated the opening of the Red Sea and the development of the Dead Sea Transform Fault (DSF). Lateral closure apparently progressed gradually, completing the length of the Bitlis suture almost 5 million years ago. 


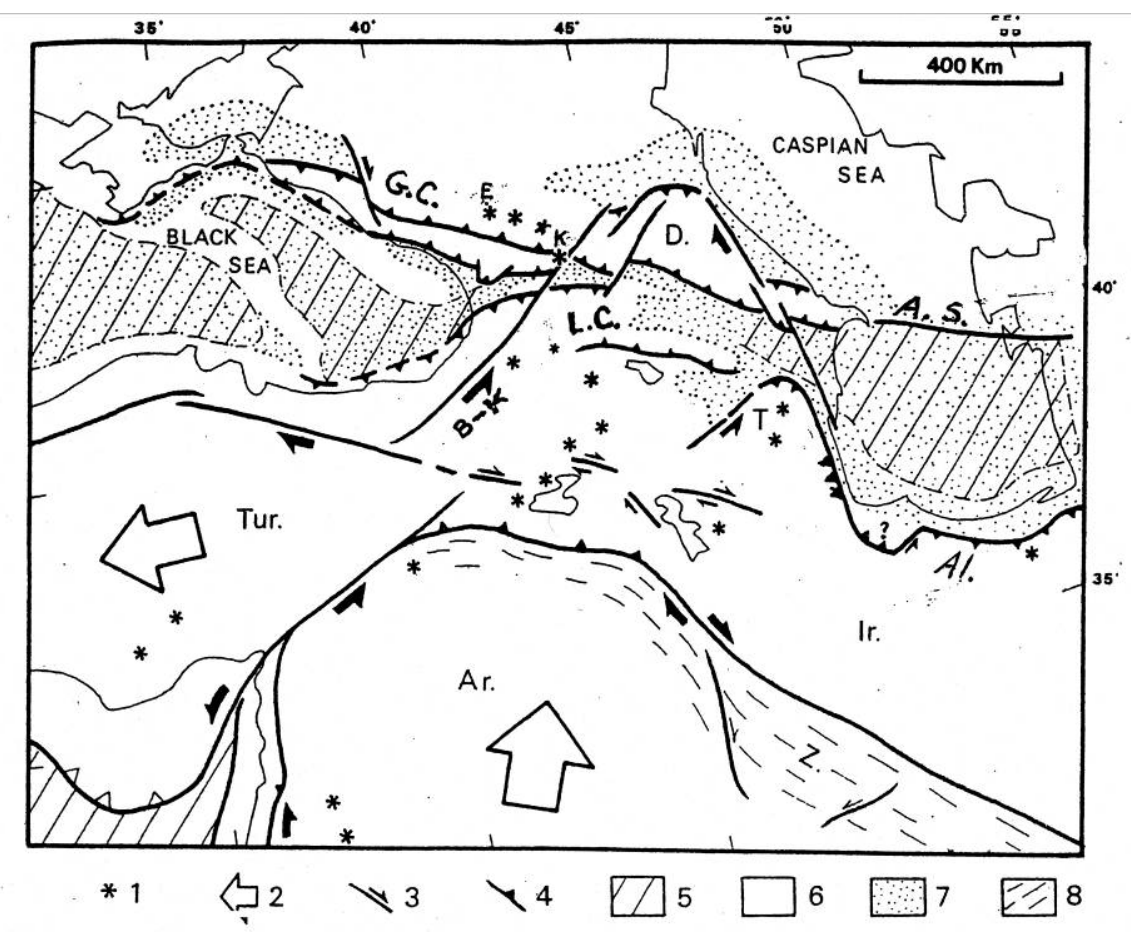

Figure 2-3: Present-day tectonic features characterizing the areas surrounding the Caucasus. 1 = recent volcanoes; $2=$ Relative motion with respect to Eurasia; 3 = major strike-slip faults; $4=$ major thrust faults; $5=$ oceanic or intermediate crust; $6=$ continental crust; $7=$ main sedimentary basins; $8=$ recent folding at the border of the Arabian Plate. G.C. - Great Caucasus; D- Dagestan; LC - Lessor Caucasus; T- Talesh; AL - Alborz; Ir. - Iranian block; Tur. - Turkish block; Ar- Arabian Plate; Z - Zagros; $\mathrm{K}$ - Kasbeg volcano; E - Elbruz volcano. 

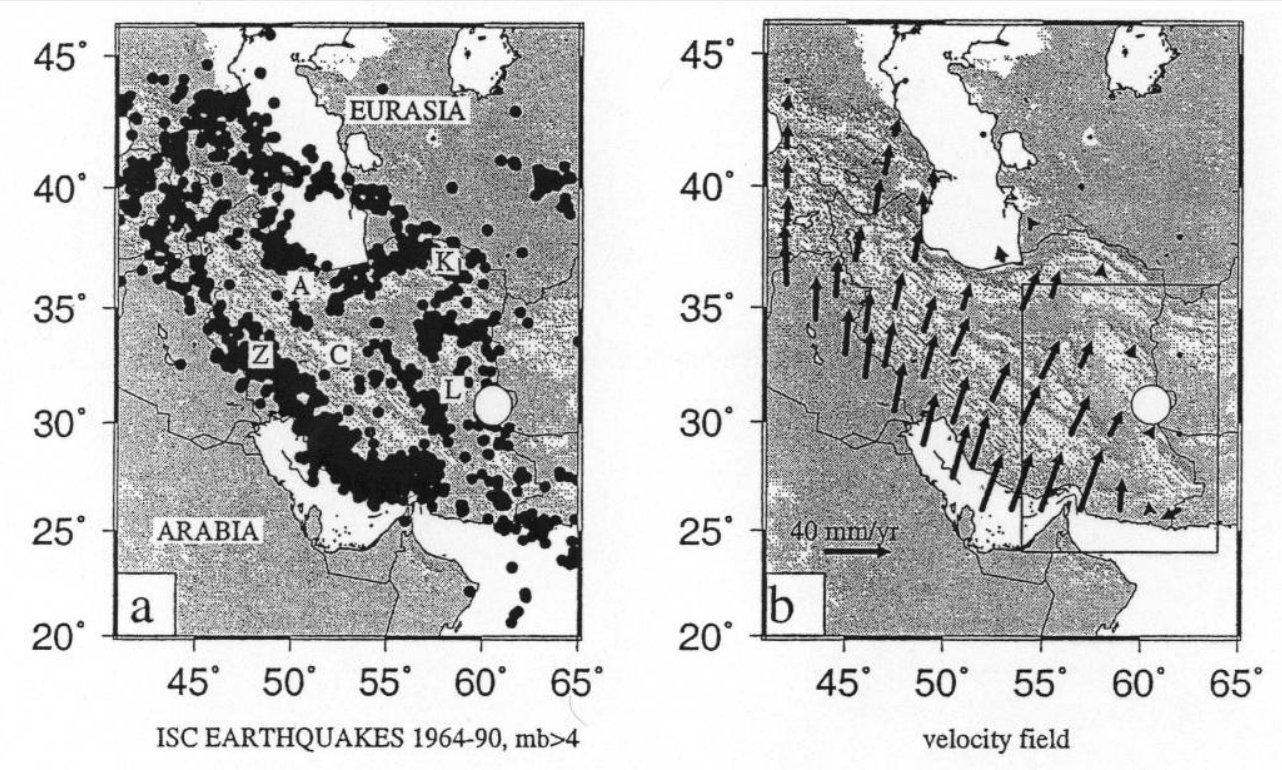

Figure 2-4: (a) Seismicity of Iran 1964 - 1990. Note how the cutoff in seismicity follows the NE and E borders of Iran. The Zagros is marked by Z, the Alborz by A, the Kopeh Dagh by K, the relatively aseismic central Iran block by $\mathrm{C}$, and the Lut block by $\mathrm{L}$.

(b) A velocity field for Iran showing how the NNE motion of Arabia relative to Asia is absorbed in Iran. The distribution of velocities within Iran is estimated from the spatial variation in the style of strain rates indicated by earthquakes. 


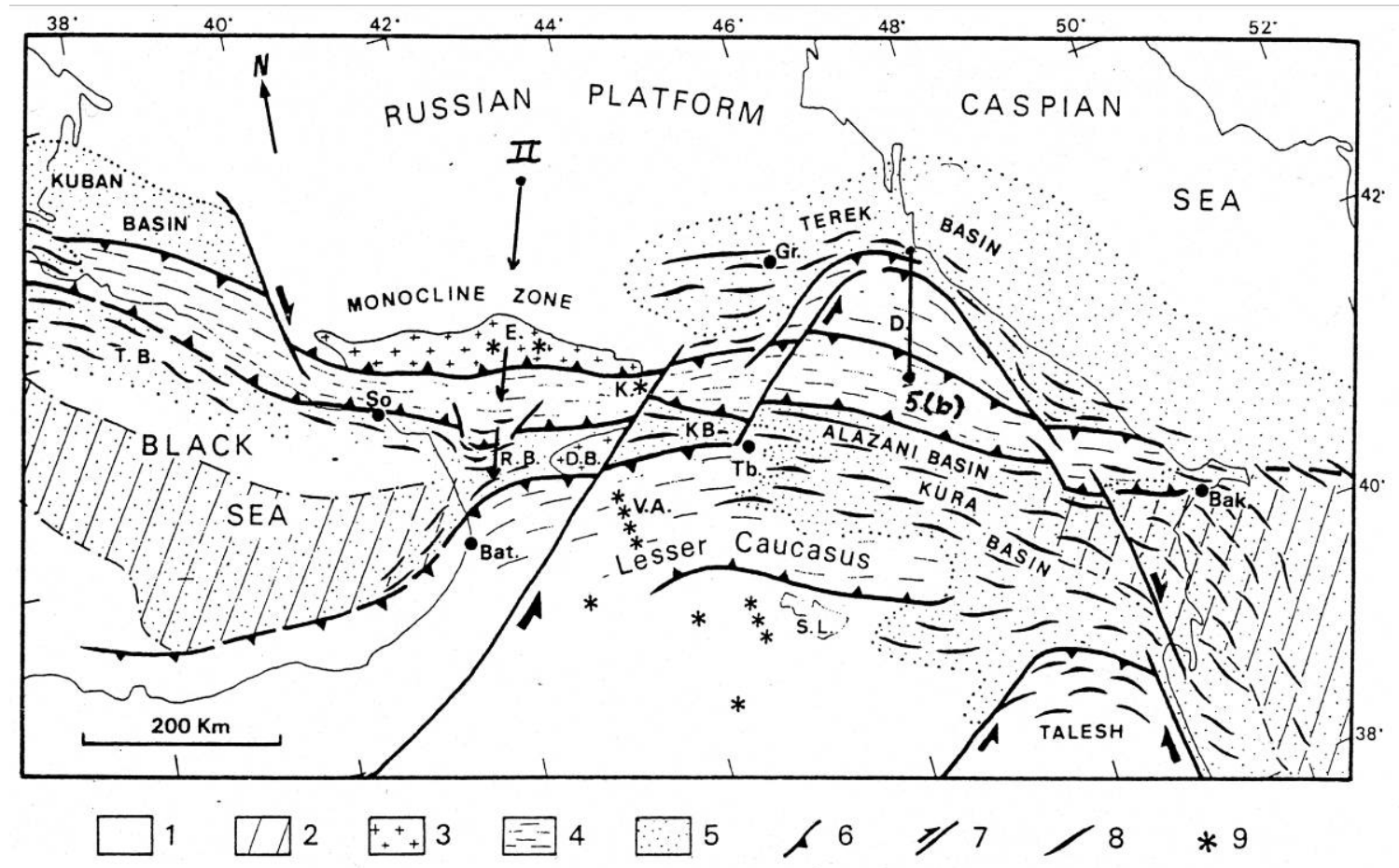

Figure 2-5: Simplified structural map of the Caucasus. $1=$ continental crust; $2=$ oceanic or intermediate crust; $3=$ outcrops of the continental basement; 4 = folding within Mesozoic to Paleogene sediments; 5 = young sedimentary basins; $6=$ major thrust faults; $7=$ major strike-slip faults; 8 $=$ Folding within young sedimentary basins; $9=$ Neogene to Quaternary volcanoes. T.B. - Tauapse basin; R.B. - Rioni basin; D.B. - Dzirula block; S.L. - Sevan Lake; D - Dagestan; V.A. - volcanic axis of Akhalkalak, K.B. - arthaliny basin; Tb. - Tbilisi; E. - Elbruz; K. Kazber; G. - Grozny; Bak. - Baku; Bat. - Batum; So. - Sokoumi (adapted from Philip et al., 1989). 


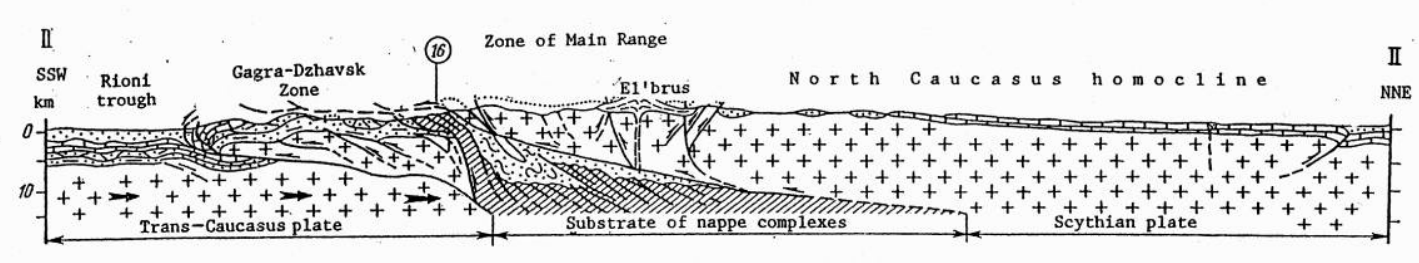

$10 \mathrm{~km}$

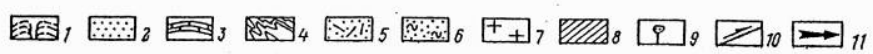

Figure 2-6: Profile through the Central Caucasus showing the supposed structure of depth. (1) Upper Pliocene - Holocene volcanics from El'brus volcano; (2) molasses; (3) Malm-Eocene shallow-water sediments; (4) the same, subflysch and flysch; (5) Bajocian-Bathonian sediments of the Trans-Caucasus plate (including the porphyrite super group); (6) Lower and Middle Jurassic sediments; (7) pre-Jurassic basement of the TransCaucasus and Scythian plates; (8) substrate of the Goytkhsk-Tfan and Novorossiysk-Dibrar nappe complexes; (9) Alpine intrusions; (10) faults and thrust surfaces; (11) direction of predominant displacement of crustal masses.
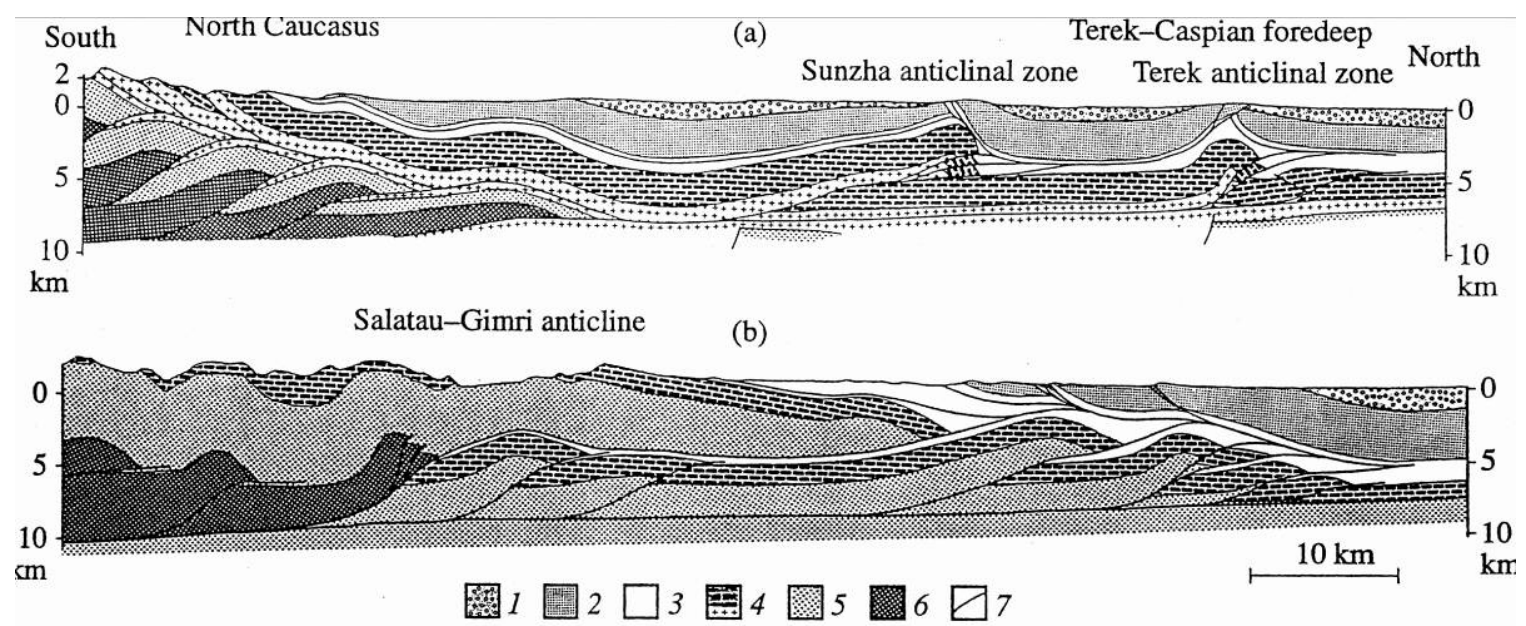

Figure 2-7: Geologic sections of (a) Terek-Sunzha fold zone and (b) Dagestan wedge. (1-6) Stratigraphic complexes; (1) PlioceneQuaternary; (2) Upper-Middle Jurassic; (3) Oligocene-Lower Miocene (Maikop Group); (4) Upper Jurassic-Eocene; (5) Lower-Middle Jurassic; (6) Paleozoic-Triassic; (7) faults. 


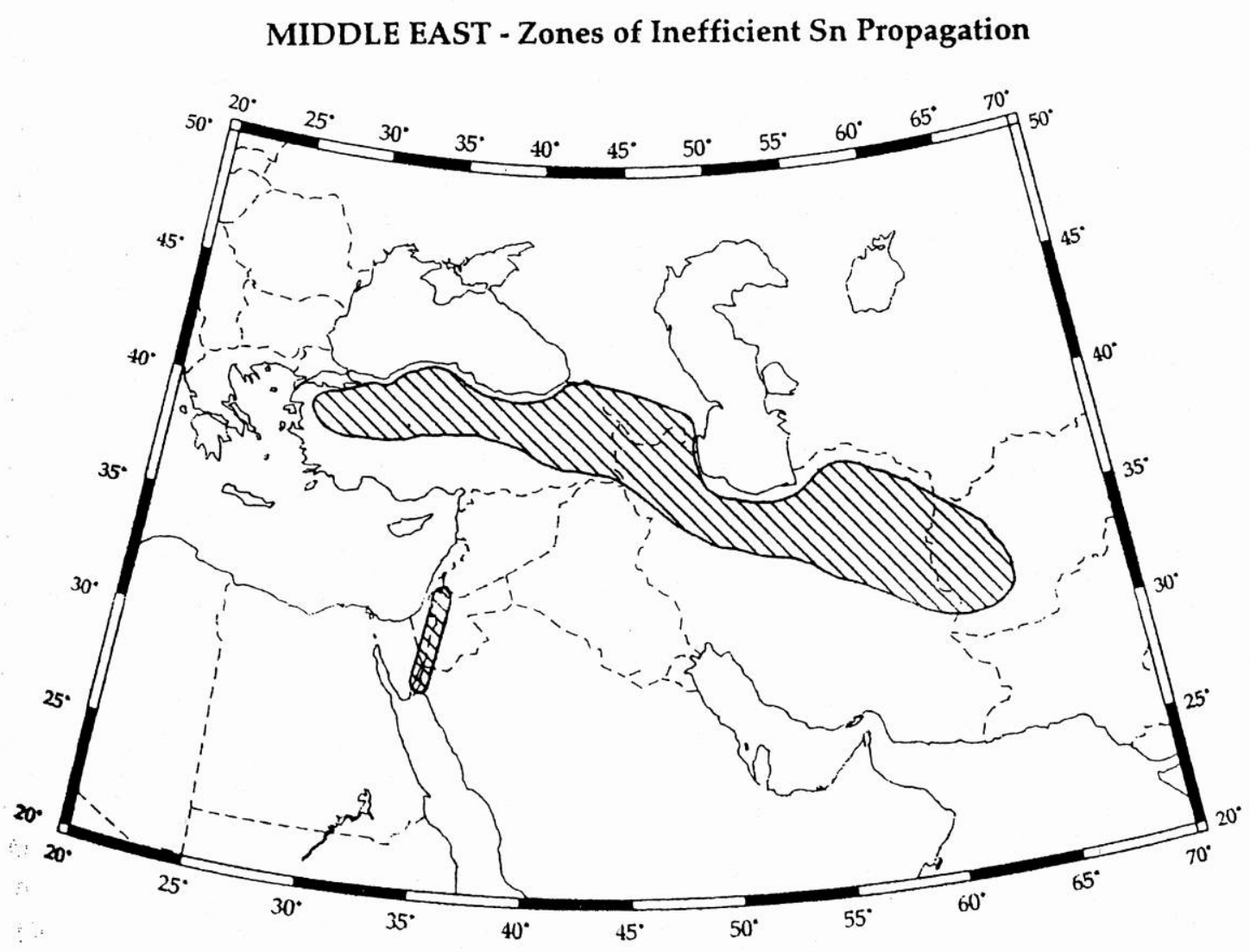

Figure 2-8: Summary figure showing the zones of inefficient $S_{n}$ propagation based on the combined results of Kadinsky-Cade et al. (1981) and Rodgers et al. (1997). Efficient $S_{n}$ propagation is found for the surrounding regions of the Arabian shield and the Mediterranean, Black, and Caspian Seas. 


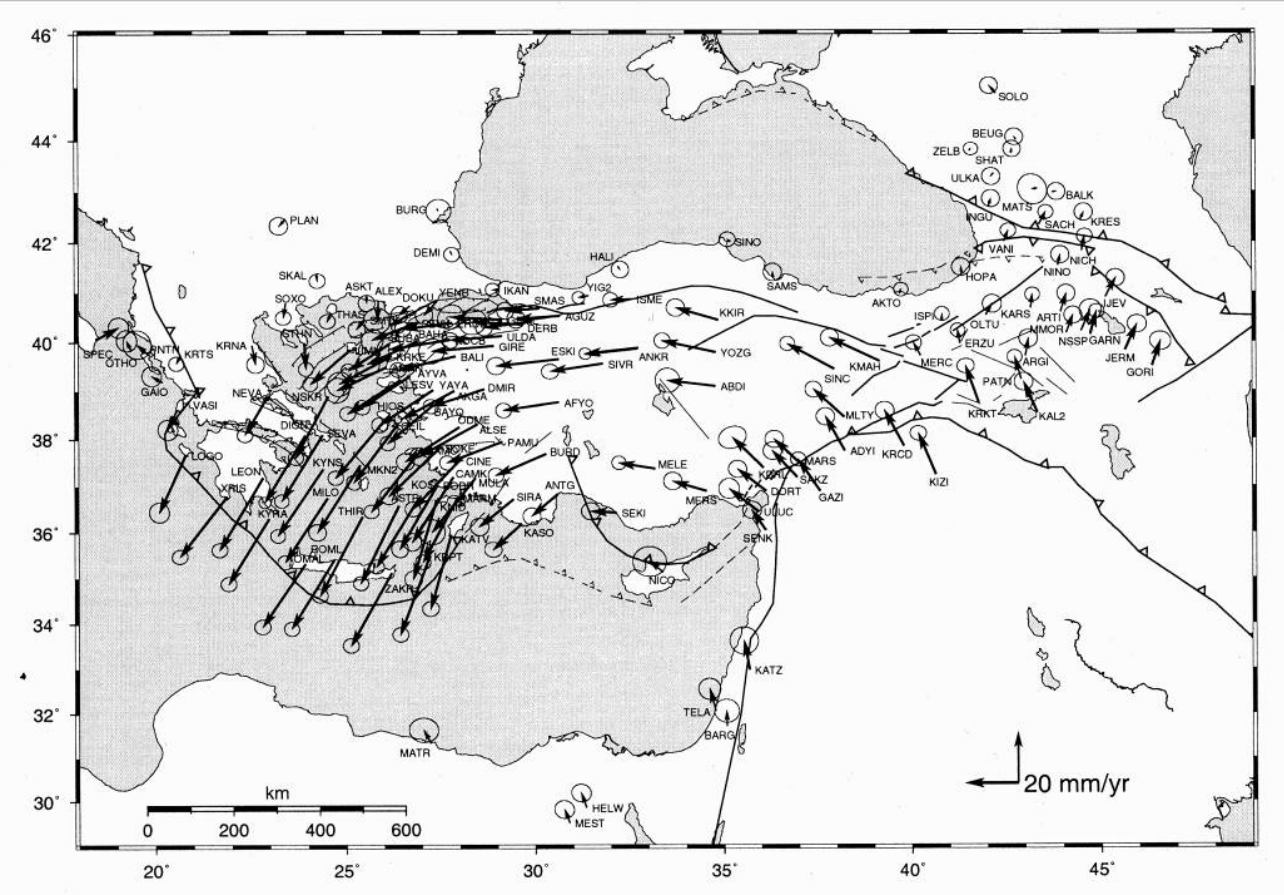

Figure 2-9: GPS horizontal velocities and their 95\% confidence ellipses in a Eurasia-Fixed reference frame for the period 1988-1997 (McCluskey et al, 2000). 


\title{
Chapter 3: The Borjomi-Kazbegi Fault: Geological and Geophysical Study Results
}

\begin{abstract}
The Caucasus region has long been considered an example of indenture tectonics. The proposed Borjomi-Kazbegi sinistral fault is considered the western boundary of the actively indenting wedge. However, an improved seismic network density has led to recent unpublished observations noting a lack of seismicity on the proposed BorjomiKazbegi fault. These new observations call into question the existence of the fault, and with it, the tectonic model of the region.

To clarify this anomaly, field research was carried out during the summer of 2005 and spring of 2006 on different portions of the proposed Borjomi-Kazbegi fault zone (BKFZ). Since the BKFZ is also proposed to be a major crustal structure, a multidisciplinary approach was utilized for this investigation, using both geological and geophysical methods.

Part of the study involved observing surface expressions of the local geology in an effort to measure the displacement which would be expected from a major strike-slip fault. Precise GPS instrumentation was used to map multiple local geologic marker beds across the proposed line of the fault. These marker beds include lithologic contacts, structural folds, quaternary lava deposits and several sills. All localized marker beds continue uninterrupted across the proposed fault zone; when combined with the regional data they suggest that the proposed fault does not exist.

Gravity and magnetics were also carried out to look for deeper structures. Data from these surveys show no discontinuity across the proposed fault line. In addition, the gravimetric data collected during the summer of 2005 agrees with the results of a gravity survey carried out during the Soviet period. The Soviet data covers a greater portion of the Lesser Caucasus, and also shows no evidence of a major strike slip fault in the region. Currently, the field observations support a model that suggests active shortening in the Borjomi region is accommodated predominantly by thrust faulting.
\end{abstract}




\subsection{Introduction}

The Caucus is a region of active tectonics and complex crustal structure located between the Caspian Sea to the east and the Black Sea to the west. To the north is the aseismic Eurasian shield, and to the southwest and the south are the active tectonic regions of East Anatolia and the Zagros thrust and fold belt of northwestern Iran. (Fig. 31.)

Most knowledge of the tectonics and geology of the region is based on fieldwork and seismic studies undertaken during the Soviet era. Knowledge of the region among western scientists has been subject to numerous logistical complications; Western researchers were forbidden entry into the region until the collapse of the USSR in 1991. Subsequent social unrest and political instability have also limited foreign access. In recent years however, foreign scientists have been able to gain a greater research presence through joint projects with scientists in the Caucasus.

A major goal of this project was create a database of regional geology and active tectonics. In doing so, a controversy developed over the existence of the BorjomiKazbegi fault zone (BKFZ), a left-lateral strike-slip fault which is a major feature of many tectonic models of the Caucasus, such as that in Fig. 3-2. The SW-NE trending BKFZ is a proposed extension of the East Anatolian fault (EAF) in Eastern Turkey. While seismic and surficial evidence of the EAF is abundant (Örgülü, et al., 2003, Copley and Jackson, 2006), the evidence of its extension into Georgia is controversial; Georgian geophysicists report little evidence for recent faulting, and, until recently, earthquakes locations and source mechanisms have been of poor quality. 
To resolve this issue, geological and geophysical fieldwork was performed in the Republic of Georgia on three portions of the BKFZ. No evidence of the fault's existence was found.

This chapter presents the results of the fieldwork. Also, the role of the BKFZ in existing tectonic models of the Caucasus is discussed, as well as and the prior evidence of the BKFZ's existence.

\subsection{Tectonic Models Of the Borjomi-Kazbegi Region}

The Caucasus region is actively deforming due to the continuing indentation of the Arabian Plate into the Eurasian Continent (Dewey et al., 1986, which initiated in the Miocene roughly 16-23 Ma (Allen et al., 2004). Though older models have estimated a collisional rate of $25 \pm 1 \mathrm{~mm} / \mathrm{yr}$ (DeMets et al, 1990) and $18 \pm 2 \mathrm{~mm} / \mathrm{yr}$ (McCluskey et al., 2000), recent GPS and geodetic studies have shown that the rate and orientation of the collision ranges from $20 \mathrm{~mm} / \mathrm{yr}$ to $30 \mathrm{~mm} / \mathrm{yr}$, increasing from west to east (Reilinger et al., 2006). To the south of the Caucasus, the collisional strain is manifested within the Turkish-Iranian Plateau, a 3-million square kilometer area with a typical elevation of 1.5 to $2 \mathrm{~km}$ (Allen et al., 2004). North of the Turkish-Iranian Plateau the total shortening rate across the Caucasus is estimated at $10 \pm 2 \mathrm{~mm} / \mathrm{yr}$ (Jackson, 1992; Reilinger et al., 1997).

Though there is consensus on the kinematic nature of the collision, a commonly accepted tectonic model describing the active deformational structures of the region has not yet been developed. Existing models tend to fall into two classes: indenture models and slip-partition models. 
The "indenter" model is based on the plastic deformation experiments of Molnar and Tapponnier (1975) in which the proposed left-lateral BKFZ is the western boundary of the northerly migrating block. This indenting block has conceptually been described as a plastic wedge preceding the Arabian Plate (Philip et al., 1989), originating with the continental collision in the Late Miocene. Based on observations regarding the linearity of the main thrust of the Greater Caucasus, speculated variations in Moho depth from Soviet studies, and seismicity records the total displacement across the BKFZ is proposed to be $90 \mathrm{~km}$ (Philip et al., 1989). This displacement estimate conflicts with GPS derived shortening rates in the Caucasus - extrapolating a total displacement of the proposed fault would indicate offset of $18-25 \mathrm{~mm} / \mathrm{yr}$ (depending on if the fault began at the onset of the uplift of the Greater Caucasus (5 Ma) or at a proposed reorganization and intensification of collision during the middle Pliocene (3.5 Ma) (Philip et al., 1989; Allen et al., 2004).

The "slip-partition" model is not compliant with the indenter model of continental collision in the Caucasus. Rather, the collisional strain is partitioned into shear deformation south of the Lesser Caucasus (in Anatolia, Armenia and Iran) and compressional deformation both within and to the north of the Lesser Caucasus (Jackson, 1992). This implies a deformation pattern of pure thrusting and aseismic folding in the Republic of Georgia; it is not compatible with the existence of the sinistral BKFZ. The dense high velocity basements of the Black and S. Caspian Seas are speculated to guide the movement of the less dense continental crust through the Caucasus. As will be discussed below, all GPS data supports this second, slip-partition model of collision in the Caucasus (e.g. McCluskey et al., 2000; Reilinger et al., 2006). 
Both the indenter and slip-partition models of deformation note a deficiency in seismicity in the Caucasus. A seismic moment summation of selected Caucasian earthquakes has shown that as much as $90 \%$ of the shortening is aseismic (Philip et al., 1989; Jackson, 1992). Fault creep and regional folds likely accommodate this aseismic deformation.

Discrepancies between the multiple tectonic models have caused two differing fault structures for the Republic of Georgia. Fig. 3-3a (Gamkrelidze, 1998) is compatible with the indenter tectonic model as it includes the BKFZ. Fig. 3-3b (Adamia, 2004) represents the slip-partition model, resulting in only thrust and en echelon strike slipfaults in the Republic of Georgia.

\subsection{Overview of the BKFZ}

Several authors have used seismicity to support the existence of the BKFZ (Philip et al., 1989; Gamkrelidze et al., 1998). However, recent findings by CauSIN project participants have shown that using historical seismic event locations in the Caucasus may not be appropriate for an accurate identification of fault location (CauSIN workshop, Burlington VT, 2004). Despite compiling a catalogue with over 10,000 recorded events spanning the past 150 years, many have been found to be of poor data quality. Event locations have been shown to have significant errors in location, particularly with regard to focal depths. There are two ways to accurately constrain focal depths, but neither has previously been available in the Republic of Georgia. The first method to improve focal depth accuracy is to have a dense local seismic network; the second is to analyze the $\mathrm{P}$ and $\mathrm{S}$ waveforms, and then work inversely to constrain the depth through the application 
of synthetic seismograms (Jackson, 2001). Additionally, the lack of reliable ground truth data (e.g. large explosions) in the Republic of Georgia has made the derivation of an accurate crustal velocity model difficult. The Georgian Geophysical Society is working to rectify these accuracy concerns by reprocessing historical data using modern techniques (Javakashvili, Personal Communication, 2005). However, until the earthquake data has been appropriately relocated, (a task which can now be done using the updated crustal model discussed in Chapter 4 of this report), it cannot carry definitive weight.

A recent map of the epicentral locations, paleoseismicity and historical earthquakes in the Republic of Georgia (T. Godoladze, Georgian Geophysical Society, 2004) shows seismic quiescence along the southern portion of the BKFZ (Fig. 3-4). The epicentral map indicates that the Borjomi Gorge is an area of high seismicity. This seismicity however, is likely due not to a sinistral shear system, but rather to several thrusts that accommodate the N-S convergence and uplift of the Lesser Caucasus. Activities on these faults include the only major (M 5+) recorded earthquake in the region - the 1/03/1970 event in Borjomi region (Ayvazishvili et al., 1973), though a lack of records from the event prevents the calculation of a focal mechanism. A major earthquake in 1283 had been speculatively located on the BKFZ (Godoladze, 2004), but a deficiency of evidence around this event leaves its mechanics uncertain. To date, there have been no focal mechanisms in the Borjomi area indicating sinistral activity (Jackson, 1992; Javakhishvili, 2005, Personal Communication).

Proponents of the indenter model have theorized that the BKFZ is a deformational divider, separating the rapidly indenting rigid wedge from the stable Rioni Basin to the 
west (Westaway, 1990; Philip et al., 1989). This speculation was based on an apparent differential shortening across the BKFZ derived from the recorded earthquake record. However, incorporating the seismic shortening from the 1991 Racha event and appropriate aftershocks eliminates the proposed differential across the BKFZ (Triep et al., 1995).

Similarly, the BKFZ has been also been described as a seismic screen (e.g Philip et al., 1989), separating regions of high seismicity in the east from low seismicity in the west. However, geologic and microtectonic surveys (Adamia et al., 2002; Rebai et al., 1993) have shown that the cluster of epicenters to the east of Borjomi is attributed to the Javakheti Plateau, a volcanic highland. The predominant mechanism for these small magnitude earthquakes is volcanic activity and thus cannot be assigned to individual faults. These earthquakes should be considered independent of the potential BKFZ; any difference in seismicity is possibly due to a transition in mechanical properties (Triep et al., 1995).

A requisite for the indenting wedge tectonic model would be a significant increase in geodetic crustal velocities from west to east across the BKFZ. However, all GPS research in the Lesser Caucasus exhibits uniform crustal velocities throughout the entire Lesser Caucasus mountain belt (Fig. 3-5a) (McClusky et al., 2000). Further, recent GPS measurements have indicated that the Caucasus as a whole is rotating slightly counterclockwise with minimal internal deviations (Fig. 3-5b) (Reilinger et al., 2006). The lack of a significant crustal velocity differential across the strike of the BKFZ indicates that the deformational strain is parallel to the strike of the fault. 


\subsection{Field studies}

Several Georgian scientists believe that the BKFZ may be a segmented structure, alternating from strike-slip faults in Northeastern Turkey to thrusting and folding in the ATFTB to strike-slip faulting again in the Kazbegi region of the Greater Caucasus (Gamkrelidze, Chilidze; Personal Communication, 2005). For this reason, fieldwork was carried on several portions of the BKFZ as shown in Fig. 3-6.

The study area furthest to the southwest is the Borjomi Gorge, a $30 \mathrm{~km}$ lineament where the Kura River bisects the Adjara-Trialeti Fold-Thrust Belt (ATFTB) of the Lesser Caucasus. It was initially described as a geological feature of potential significance over a century ago (Abiche, 1899), but it was not until much later that Soviet scientists speculated that it might be the surficial expression of a major strike-slip fault (Bizova et al., 1973). Similar proposals have been made about the Terek (Turgi) River basin in the Greater Caucasus - the northernmost study area in Fig. 3-6 (Philip et al. 1989). The central study area is in the Kartli Basin; although Quaternary sediments from the Kura River are abundant in this region, there are outcrops which could show offset due to the BKFZ.

In all three of these areas, geologic fieldwork was carried out with the goal of identifying evidence of BKFZ, including structural analysis, observations of slickenslides, and the mapping of lithological contacts and localized marker beds for evidence of left lateral displacement across the strike of the BKFZ.

Several publications have suggested that the BKFZ exists as a deep blind fault (Gamkrelidze et al., 1998; Caputo et al., 2000). To investigate for anomalies in the 
subsurface, geophysical surveys were carried out in the Lesser Caucasus and Greater Caucasus.

\subsubsection{Geological Results in the Lesser Caucasus and Transcaucasus}

Before performing the field studies, available remote sensing information satellite imagery, aerial photography and digital elevation models (DEMs) - was investigated. Despite the Borjomi Gorge's apparent linearity, a closer analysis of the imagery shows no evidence for the existence of a major strike-slip fault. The BKFZ had been predicted to transect the E-W trending ATFTB; one would expect left-lateral offset in geologic and geomorphic structures across the strike of the gorge. However, neither the regional scale images nor the local scale images show any evidence of offset. Lateral continuity is most obvious at the frontal thrust of the ATFTB at the mouth of the gorge, as shown in Fig. 3-7.

In the field, structural continuity could be seen in the drag-fold anticline located at the front of the ATFTB (Fig. 3-8). The field observations of this fold are consistent with the remote sensing analysis of the mouth of the gorge; neither reveal sinistral offset. Additionally, GPS points were taken at the axis of this fold on either side of the gorge, indicating that the fold is linearly consistent and non-displaced.

The location of all the geological and geophysical stations in the Lesser Caucasus study area in shown in Fig. 3-9; it involved over 600 geologic points of interest and 200 geophysical stations. The geological observations included structural measurements which were recorded to investigate large-scale synclinal and anticlinal structures on both sides of the gorge. Variations in the lithology of Eocene volcanics (with respect to age) 
allowed for the mapping of geologic contacts on both sides of the gorge (Adamia, personal communication, 2005). Additionally, extremely localized marker beds allowed for close examination of minor offset. All slickensides found in the Borjomi Gorge were documented and when possible a strike, dip and rake were recorded.

Variations in volcanic lithologies throughout the Middle Eocene provided excellent markers for the investigation of lateral continuity across the strike of the BKFZ (Adamia, 2005). The field investigation found these variations to include color changes, mineral assemblage and bedding style. Throughout the entirety of the Borjomi Gorge, no sinistral offset of lithologic contacts was observed. Almost all lithologic units trend E-W across the strike of the proposed fault (Fig. 3-10). These results concur with the Soviet era field maps, which were inaccessible to previous Western field studies in the region (Fig. 3-11).

The Borjomi Gorge possesses two local beds that act as excellent markers for indications of displacement. Just north Borjomi, an E-W trending Upper Eocene sialic dyke intrudes upon the Borjomi Flysch Unit (Adamia, 2005) (Fig. 3-11b, green box; Fig. 3-12). The location of this dyke was traced across the strike of the proposed BKFZ. Field observations and GPS measurements found the dyke to be linear across the gorge. The lack of offset in the dyke indicates that no sinistral displacement has occurred in the Borjomi Gorge since the late Eocene, well before the proposed initiation of the BKFZ.

A younger marker unit was found to the south of Borjomi. Brief periods of Quaternary rhyolitic volcanism occurred in the Bakuriani area (Tutberedze, 2004). Minor amounts of red volcanics were transported by tributaries of the Kura River and deposited very locally (Figs. 3-11c, blue box; Fig. 3-13) (Adamia, personal 
communication, 2005). The distinct transition from rhyolitic fluvial deposits to soft sedimentary deposits is found directly adjacent on both sides of the gorge, indicating that no Quaternary sinistral displacement has occurred.

To investigate for fault signatures, all observed slickensides were noted and measured for strike, dip and rake. If the slickenside location prohibited physical observation (e.g. along river, on a cliff face, etc.), orientation and relative motion measurements were approximated by compass sighting. Several slickensides planes along the walls of the gorge have been cited as evidence of the existence of the BKFZ (Philip et al., 1989). These slickensides were investigated in detail and are noted by the red symbols in Fig. 3-14. Though these slickensides do parallel the strike of the BKFZ, they represent only a minor fraction of the total slickensides within the gorge.

Regionally, the slickensides show variable orientations of relative motion. There is not enough consistency throughout the Borjomi Gorge to suggest the existence of a larger continuous structure. The Borjomi Gorge bisects a fold-thrust belt that has undergone varying periods of deformation; significant deviations in slickenside orientation are expected (Adamia, 2005).

Additional geological observations were made in the Kartli Basin in the Transcaucasus region. The field investigation investigated Lower and Middle Miocene sandstone outcrops as well as the Kura River terraces for indications of displacement.. All observed outcrops support the 1:50,000 scale geologic maps (Fig. 3-15), and though no corresponding outcrops of the same age could be found on both sides of the fault, all were observed to dip north, with no evidence of structural discontinuity. 
The alluvial terraces of the Kura River also showed no indication of displacement. Beheaded streams, pressure ridges and sag ponds were not found in the field area. Quaternary fluvial terraces are continuous and no scarps indicative of an active sinistral structure were found.

\subsubsection{Geophysical Results in the Lesser Caucasus}

The difficult terrain and lack of roads within the gorge limited the extent of the geophysical survey. Approximately 200 gravity and magnetic survey points were taken in a 2-D spread in a more accessible region south of the gorge, as shown on Fig. 3-16. The relationship of the geophysical survey to the geological survey is shown on Fig. 3-9.

For correction purposes, elevations for each gravity station were taken with a differential GPS. Repetitive measurements at varying times of the day were taken at several stations to account for meter drift corrections. The Bouguer gravity anomaly is shown on Fig. 3-16 and interpreted on Fig. 3-17. A noticeable low gravity anomaly lies in the center of the field area, but there is no indication of discontinuities across the proposed fault line which we would expect if there was any subsurface displacement.

A detailed Soviet gravity survey of the whole Borjomi Gorge was provided for corroborative purposes. The fieldwork details of the Soviet data have been lost, so it is impossible to know the methodology and accuracy of the data. The Soviet study did support our field measurements and interpretations - that no subsurface offset is visible in the Borjomi area. Fig. 3-18 shows a direct comparison between the 2005 gravity data and the data collected during the Soviet era, which has more extensive coverage. The general features of the two surveys match quite well. 
The Georgian Geophysical Society was able to provide a coarse Soviet aerogravimetric survey of the ATFTB (Fig. 3-19). Though less accurate then the field survey, aerogravimetric surveys allow for a regional approximation of gravity anomalies. The survey shows linearly continuous positive and negative gravity anomalies in the Borjomi Gorge area that parallel the E-W trend of lithologies in the Borjomi Gorge. Despite the coarse nature of the study, these anomalies do not appear to be offset across the strike of the BKFZ, and certainly not offset to the $90 \mathrm{~km}$ assumption predicted by some of the literature (Philip et al., 1989).

The magnetic survey was carried out with two proton-precession magnetometers; a base magnetometer that recorded diurnal variations and a field magnetometer. Five magnetic measurements were taken in a $10 \mathrm{~m}$ grid around each gravity station to help ameliorate interference caused by surficial noise. Located $25 \mathrm{~km}$ northeast of the field area in Bakuriani, the base magnetometer took readings continuously throughout the field campaign at an interval of 2 minutes.

However, the results of the magnetic survey, shown in Fig. 3-20, were deemed inconclusive due to excessive error. Despite our efforts, many of the stations were located in proximity to power lines, metal fences, and metallic debris, and the local magnetic disturbances they caused masked the broader magnetic signatures of geological structures.

The Georgian Geophysical Society also provided a Soviet era aeromagnetic survey of the ATFTB (Fig. 3-21). The regional magnetic data coincides well with the geologic data. As the Borjomi Gorge is comprised mainly of volcanics, which are high in metallic content, most of the gorge shows a positive magnetic anomaly. The clastic 
Borjomi Flysch, which would be expected to have no anomalous signature, is represented by a linear band of low magnetics. As with the geologic observations, no sinistral offset is noted; the magnetic highs and lows continue uninterrupted across the strike of the BKFZ.

\subsubsection{Geological Results in the Greater Caucasus}

The investigation for displacement across the strike of the BKFZ examined minor temporal lithologic variations within the Jurassic black slate. These variations have distinguished the black slate into four different sub-facies (Fig. 3-22, A-D) (Adamia, 2005). The Kistinka formation (Sinemurian Age), is comprised almost wholly of very fine grained black slates with occasional intrusions of light colored volcanics. The Kistinka Formation is overlain by the Tsiclauri Formation (Pleinsbachian Age), which features a 50/50 combination of black slates and diabase dykes and frequent boudins. The Kazbegi Formation (Toarcian Age) features a combination of black slates and sandstone beds. The sandstones in the Kazbegi Formation vary in thickness, making them excellent marker layers. Finally, the Kazbegi Formation transitions into the Bursachiri Formation (Bajocian Age); composed almost entirely of fine grained black slates, with minimal sandstone content

The black slates are covered in several areas by Quaternary volcanics (Fig. 3-22, E). These volcanics are dacite/andesite in composition and Soviet era $\mathrm{K} / \mathrm{Ar}$ dating found a range in age from $455( \pm 40)$ to $15( \pm 15)$ thousand years. The cause of the volcanism remains enigmatic, further study is necessary to determine the subsurface nature of the region. 
Geologic maps with scales of 1:100,000 and 1:250,000 were provided by the Georgian Geologic Institute and GeoEcoTAU (Adamia, 2005) (Fig. 3-23). These maps show the E-W strike of the regional geology and have been updated by field surveys as recently as 2004 (Adamia, personal communication, 2006). None of the geologic maps show any indication of sinistral displacement in the vicinity of the BKFZ. The goal of the field investigation was to verify these maps.

The field survey investigated both sides of the Terek River Valley in detail and found no indication of sinistral displacement. All lithologic contacts and marker beds were mapped continuously across the strike of the BKFZ (Fig. 3-24). Further, all structures (folds and thrust faults) were laterally consistent. The results found in the field investigation were consistent with the older geologic maps.

\subsubsection{Geophysical Results in the Greater Caucasus}

Fieldwork in the Kazbegi region was severely hampered by late winter storms that blocked passage to the field area, and by an unseasonable cold snap that rendered the gravimeter unusable. For this reason, only the magnetic survey could be carried out. Fortunately, the study area near Kazbegi was more amenable to magnetics than the field area in the Lesser Caucasus. Given the difficulty of the terrain, there are less settlements in the Greater Caucasus, therefore less metallic debris to interfere with the signal.

Though not as common a geophysical fault identification method as gravity, measuring magnetic susceptibility has been used to help resolve the locations of buried strike-slip faults in California and Central Asia. There are two contrasting theories on the type of magnetic anomalies caused by an active strike-slip zone. The first theory 
suggests that the magnetic susceptibility will decrease across the fault zone, as the shear stress help to break down magnetic minerals. These minerals are then either leached or transported out of the fault zone, causing the drop in magnetic susceptibility (Bailey, 1974).

A second contrasting theory asserts that a buried strike-slip fault will cause an anomalous increase in magnetic susceptibility. This increase would be due to fluid flow carrying heavy metals along the active fault planes. The magnetic susceptibility would increase gradually until it reached its peak above the fault plane, as the fluid flow would cause the surrounding soils to be enriched as well. Based on these two theories, the goal of the magnetic survey was to search for any type of continuous magnetic anomaly, particularly one that strikes similar to the proposed BKFZ.

Fig. 3-25 shows the results of our magnetic survey in the Kazbegi region. We found negative magnetic anomalies when we neared the Quaternary volcanics, but little variation otherwise.

\subsection{Discussion/Conclusions}

The findings of this fieldwork are not compatible with the existence of the BKFZ. Key marker beds in the Lesser and Greater Caucasus strike E-W uninterrupted on both sides of the BKFZ and continuous geophysical anomalies indicate no subsurface sinistral offset. The lack of physical displacement combined with the negligent seismic expression provides no evidence for the presence of the BKFZ. Further, all geologic observations and seismic data indicate that shortening in the ATFTB is predominantly thrust faulting and aseismic folding. 
Contrary to the conclusions expressed in previous publications (Philip et al., 1989; Koronovskii et al., 1996), the origin of the Borjomi Gorge is likely erosional. Coarse space imagery suggests the Borjomi Gorge strikes conspicuously N20E. However, higher resolution imagery (RasterRoam, Aerial Photography) indicates that the Kura River meanders both E-W as well as N-S throughout the gorge; its path is not nearly as linear supposed. The Kura River is the main transport mechanism for the ATFTB catchment, carrying a large volume of water and sediment. These act to erode the Borjomi Gorge laterally and vertically. Further, the spreading of Quaternary lava flows around Borjomi (Fig. 11A, red box) indicates that the river and gorge is old (at least 1 m.y. based on the estimated age of the lava flows) (Tutberidze, 2004). The combination of erosion and old age suggests the evolution of the Borjomi Gorge can be attributed to gradual geomorphic processes.

The lack of sinistral offset in the ATFTB indicates the "indenter plate" model does not accurately describe the far field deformation of continental collision in the Caucasus, rather, the strain-partition model of continental collision (Jackson, 1992) more closely fits our findings.

However, the fieldwork completed in this study is not comprehensive enough to completely discredit the indenter model for the whole of the Caucasus. One possibility is that the westward migration of the Anatolian microplate causes strike-slip and extensional tectonics to the south of the Caucasus. Though sinistral faulting exists in NE Turkey (Kelkit-Çoruh and Posof fault zones) (Koçyiğit et al., 2001), the collisional strain is partitioned into thrust faulting and aseismic folding in the Republic of Georgia (Jackson, 1992). The dense basements of the Black and Caspian Seas likely guide the 
continental crust within the Caucasus. Effectively, the presence of dense high velocity crust beneath the Black and S. Caspian Sea basins prohibits continental material from escaping laterally and limits the strain in the Caucasus to be of a N-S compressive nature. The fault map of Georgia that appropriately exhibits this model of continental collision is the interpretation of Adamia in Fig. 3a.

To further our understanding of the tectonics of the Caucasus region, major seismic events should be relocated according to the model developed in Chapter 4 of this report, and to use data provided by the expanding networks in the region to quantify source mechanisms of recent and future events.

Acknowledgements: Major contributors to this section include Timothy O'Connor, (Boston College) and Mary Krasovec (New England Research, Inc.). 


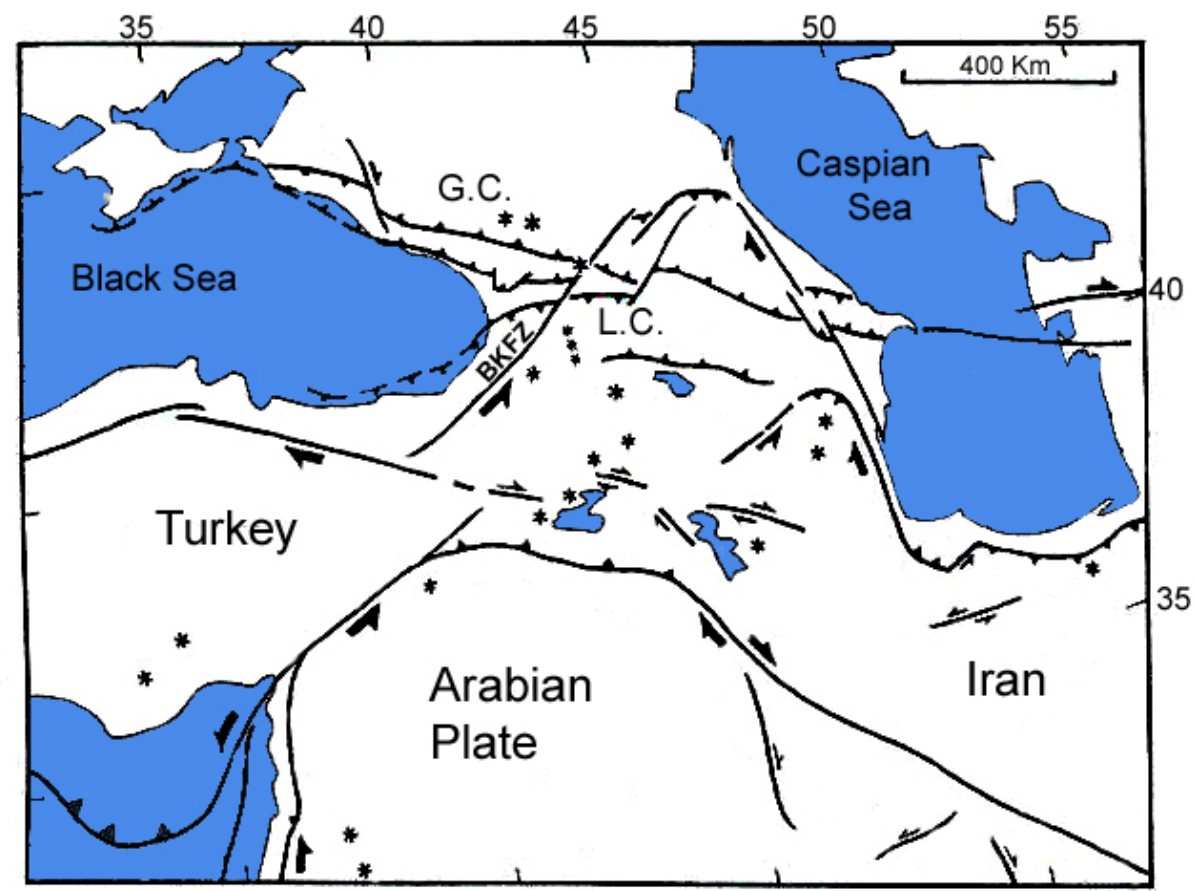

Figure 3-1: Tectonic Model of the Caucasus (after Philip et al. 1989). Note the indenting wedge between the Black and Caspian Seas caused by the northerly migration of the Arabian Plate. The proposed BKFZ is the western boundary of this indenting wedge. The * symbol denotes areas of volcanism. 


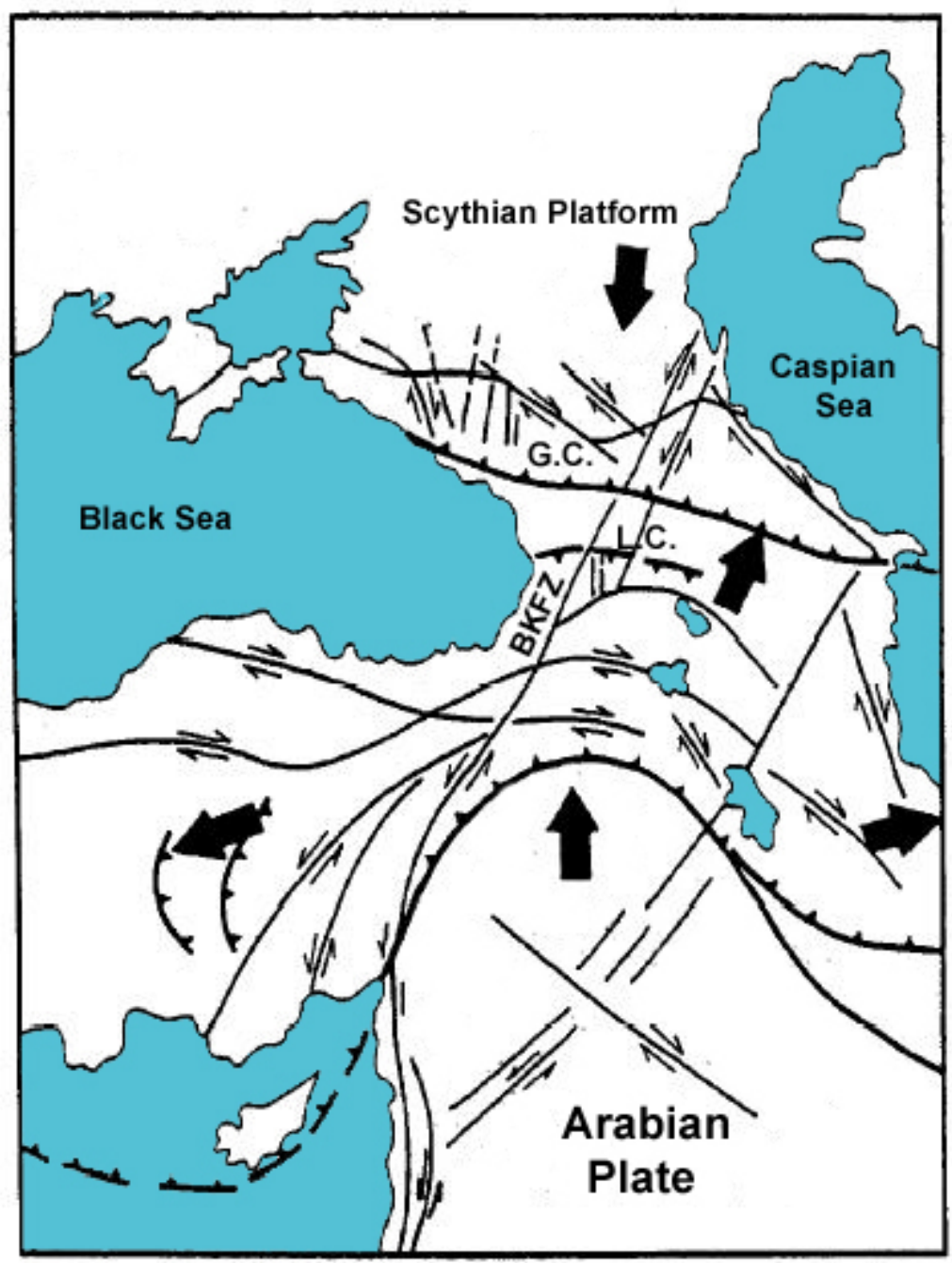

Figure 3-2: Tectonic Model of the Caucasus (after Koronovskii et al., 1996). The BKFZ is a component of a larger sinistral fault system stretching from the Dead Sea to the Caspian Sea 


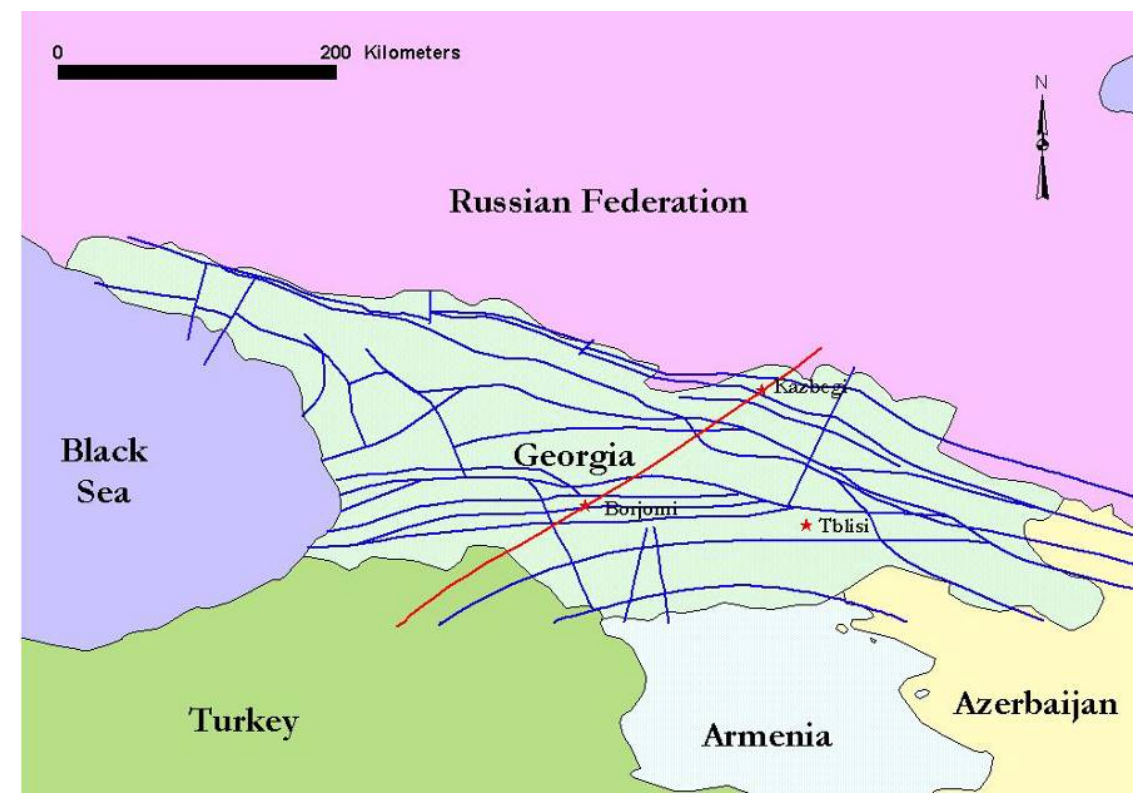

Figure 3-3a: Fault structure of the Republic of Georgia, after Gamkrelidze et al. (1998). The proposed BKFZ is shown in red.

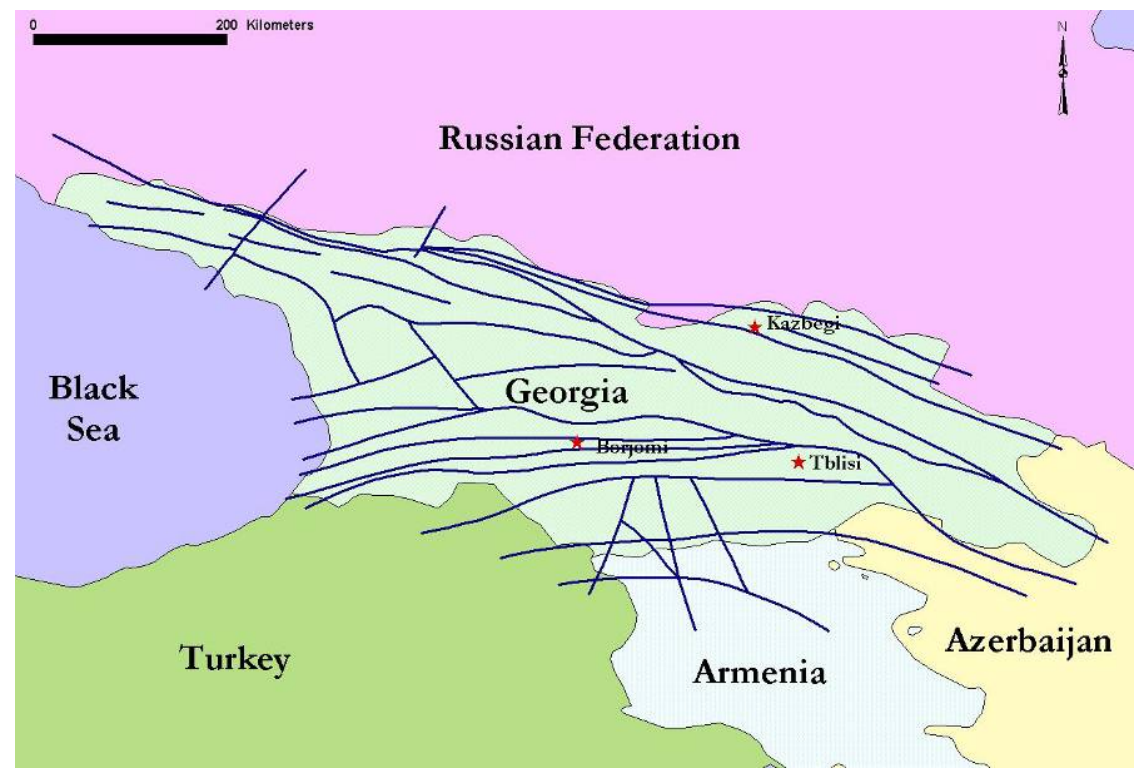

Figure 3-3b: Fault Structure of the Republic of Georgia, after Adami (2004). The BKFZ is not compatible with this fault model. 


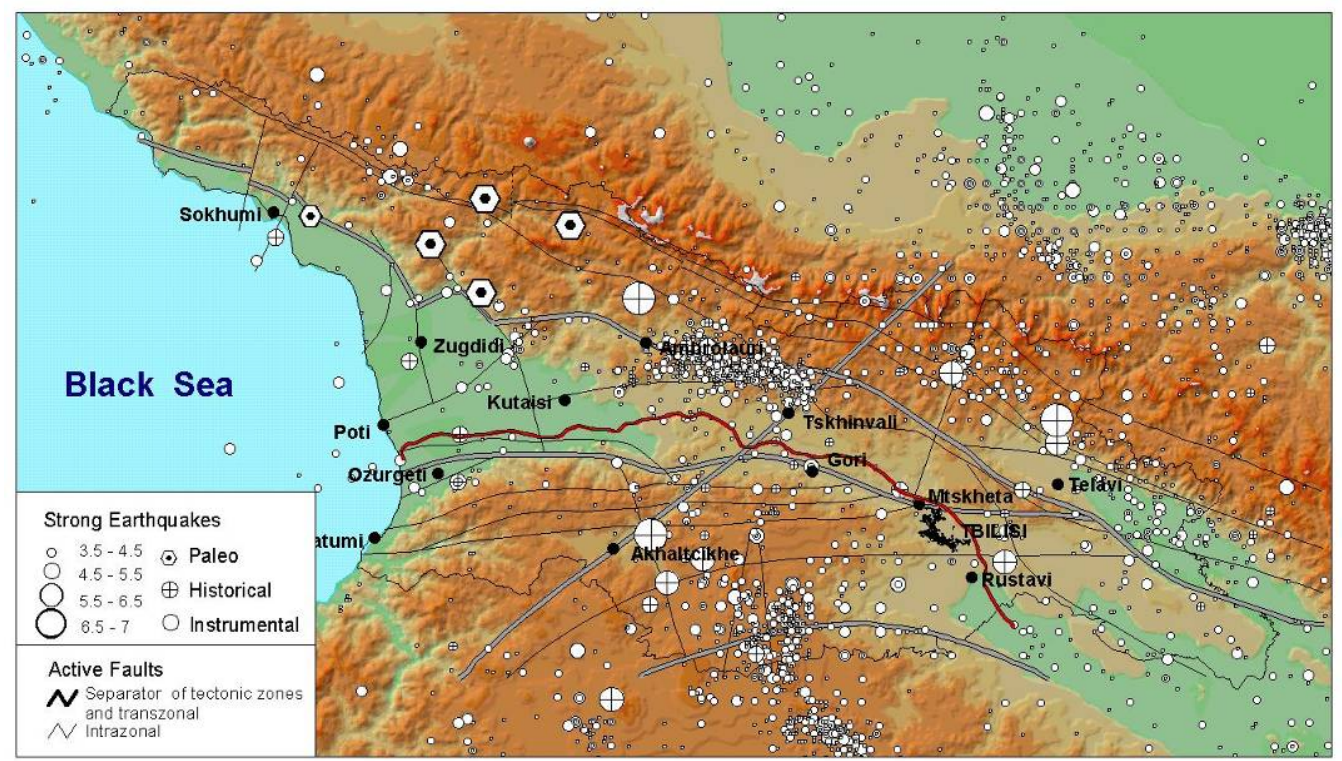

Figure 3-4: Map of epicenters of major earthquakes in the Republic of Georgia. The BKFZ has a marked seismic quiescence. (figure courtesy of the Georgian Geophysical Society) 


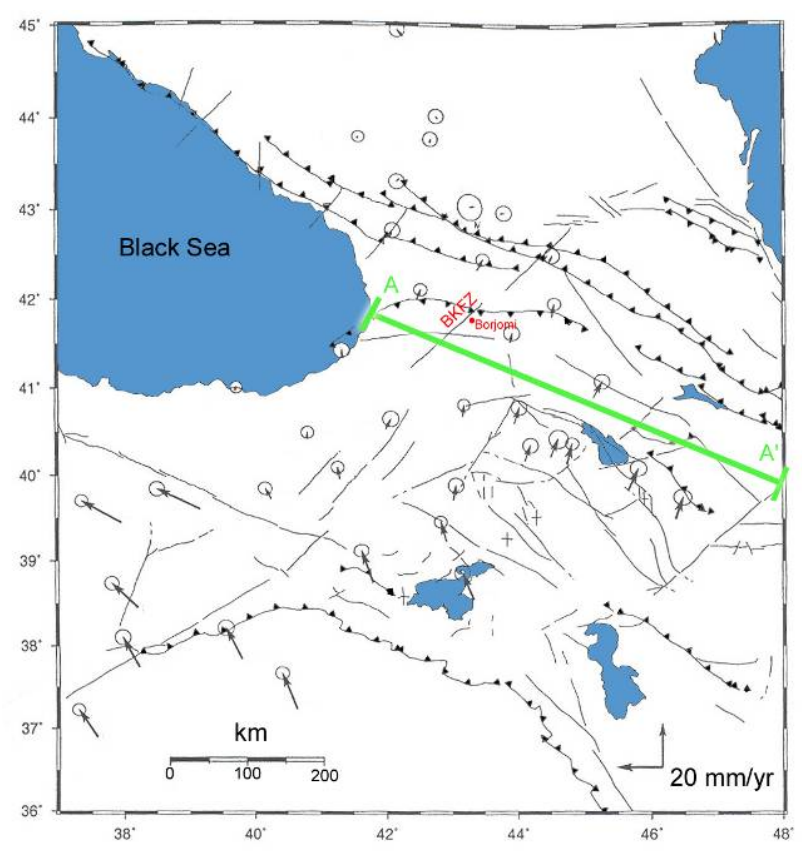

Figure 3-5a: Map of geodetic motion in the Caucasus as recorded by GPS. The rates and deformation of crustal movement are consistent on both sides of the fault. (After McClusky et al., 2000)

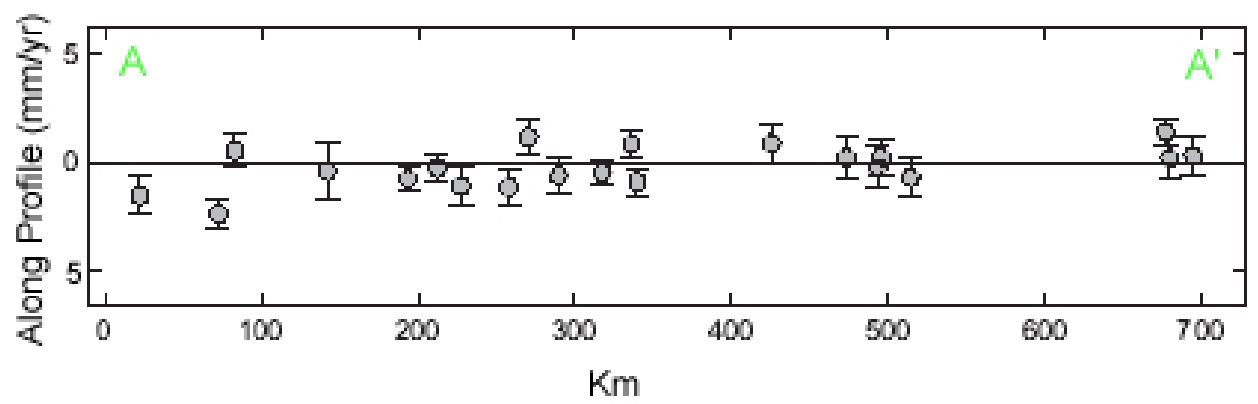

Figure 3-5b: Rates of deformation at GPS stations along profile A-A' found in Fig. 3-9a. The consistent geodetic velocity rates show that deformation is constant throughout the Caucasus. The BKFZ does not increase the rate of deformation from west to east. (After Reilinger et al., 2006) 


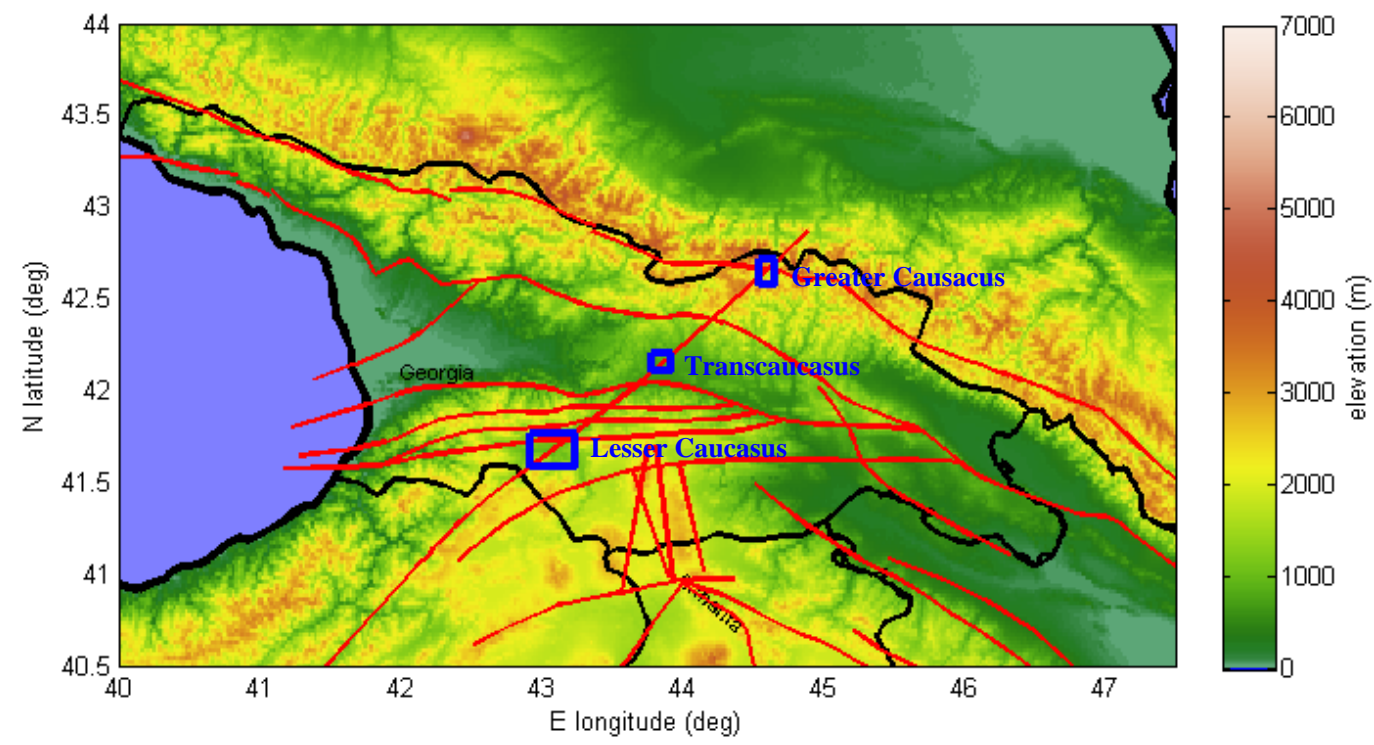

Figure 3-6: Field studies were carried out in three locations: the Borjomi Gorge in the Lesser Caucasus if Southern Georgia, the Kartli Basin in the Transcaucasus, and the Turgi River Gorge in the Greater Caucasus to the north. 


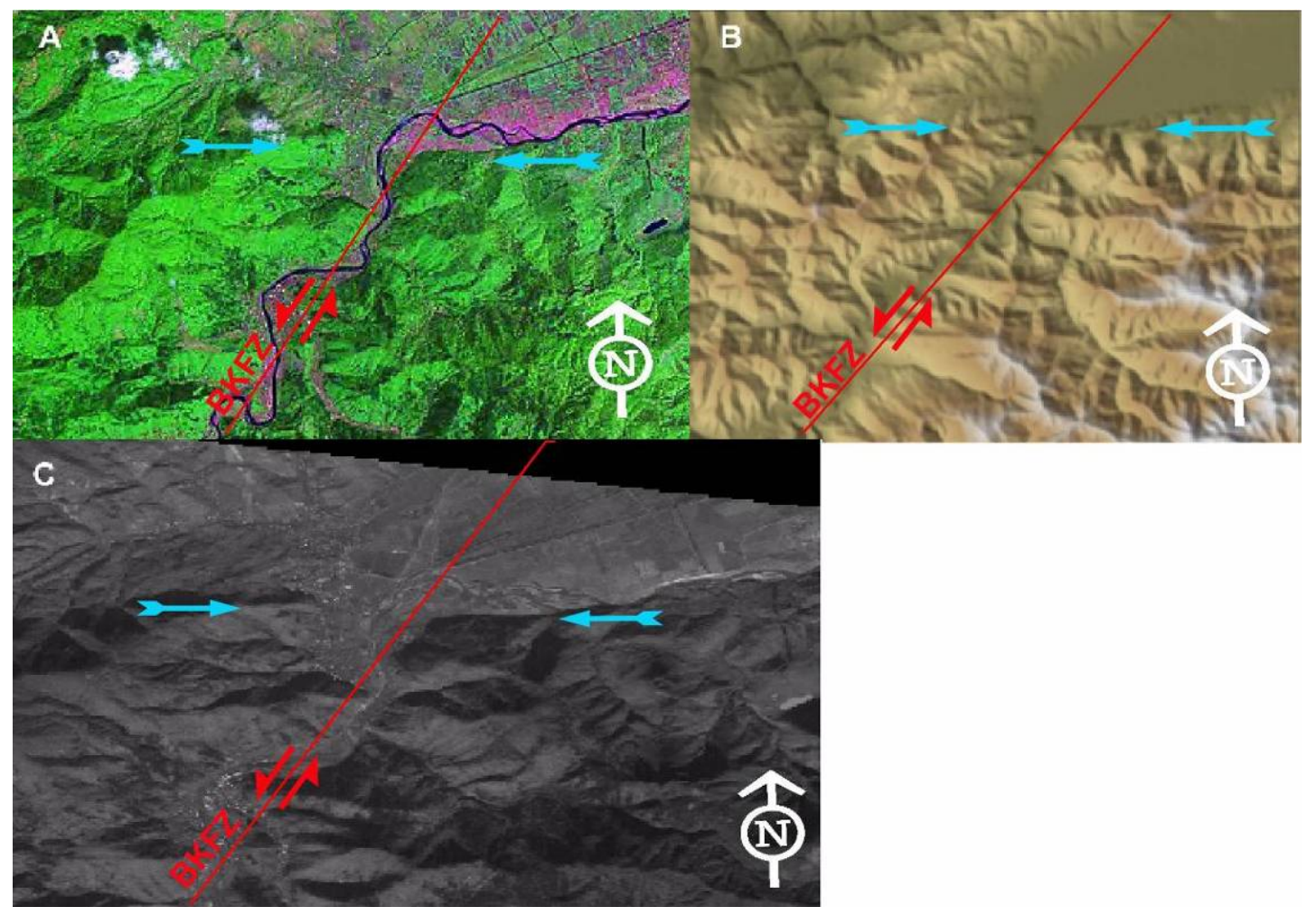

Figure 3-7: Three different remote images of the front of the ATFTB. The approximate location of the proposed BKFZ is shown in red. The blue arrows denote the front of the ATFTB. A - Landsat Image; B SRTM DEM; C - RasterRoam Image. All three images reveal no displacement across the strike of the BKFZ. 


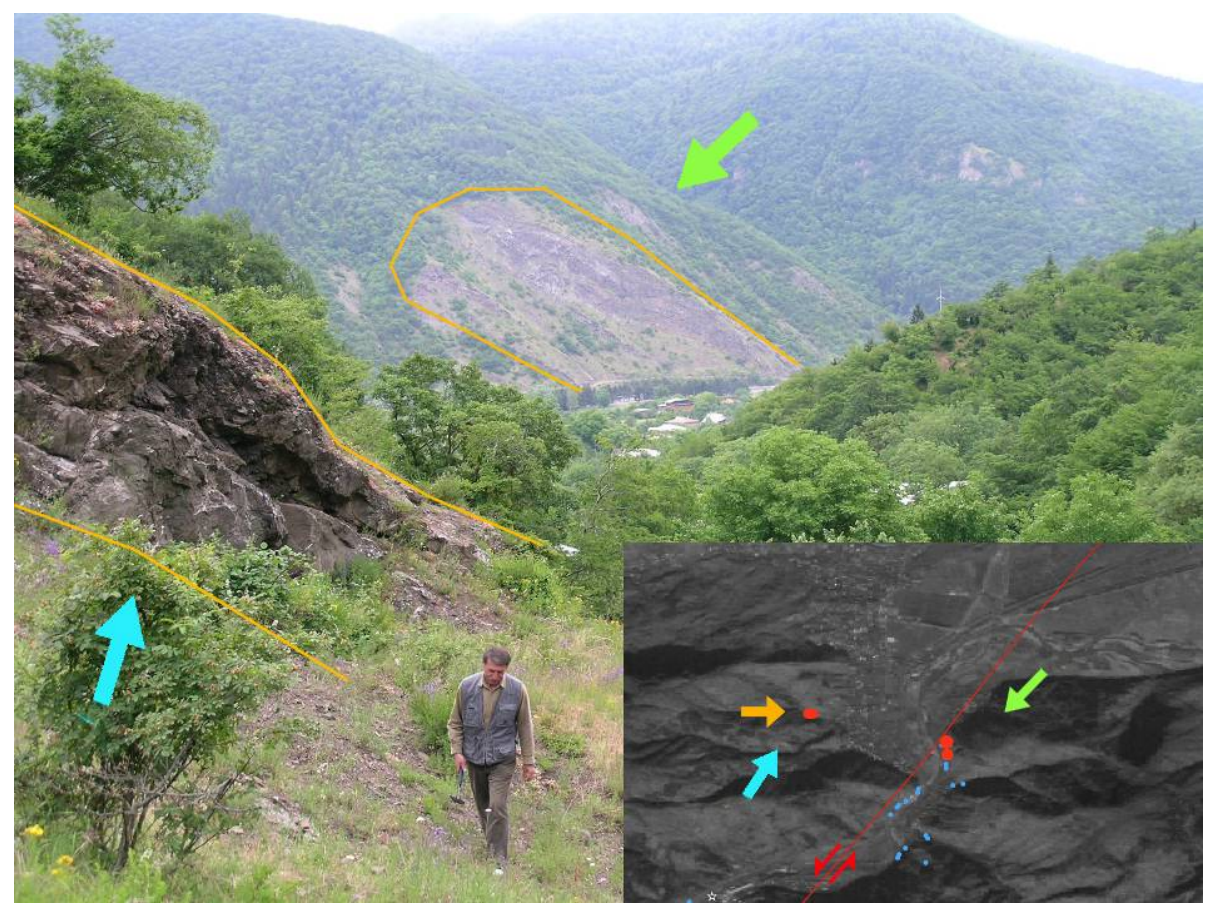

Figure 3-8: The uninterrupted front of the Adjara-Trialeti Fold-Thrust Belt. The orange arrow in the inset denotes the location and orientation of the picture. The axis of the drag-thrust fault is found within the orange lines. The blue and green arrows show relative position of these outcrops across the strike of the fault. The red points are measurements of the axis of the drag fold. 


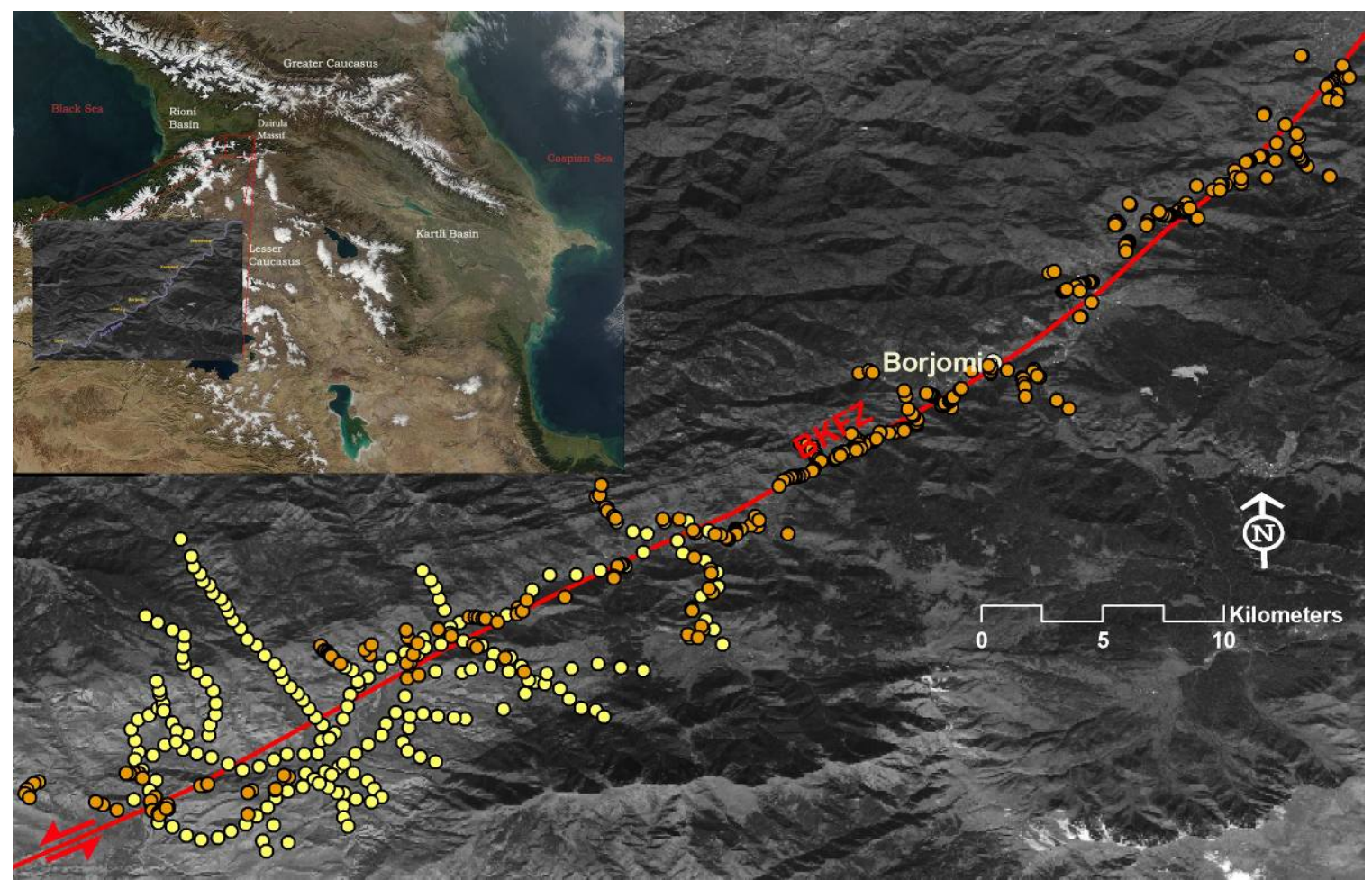

Figure 3-9: Location of the Borjomi Gorge and the scope of the field area.

The inset shows the location of the Borjomi Gorge in relation to the Caucasus region. Over 600 GPS points were identified in the geologic and geophysical investigation. The orange markers represent the points taken in the geologic investigation, the yellow points show stations in the geophysical survey. 


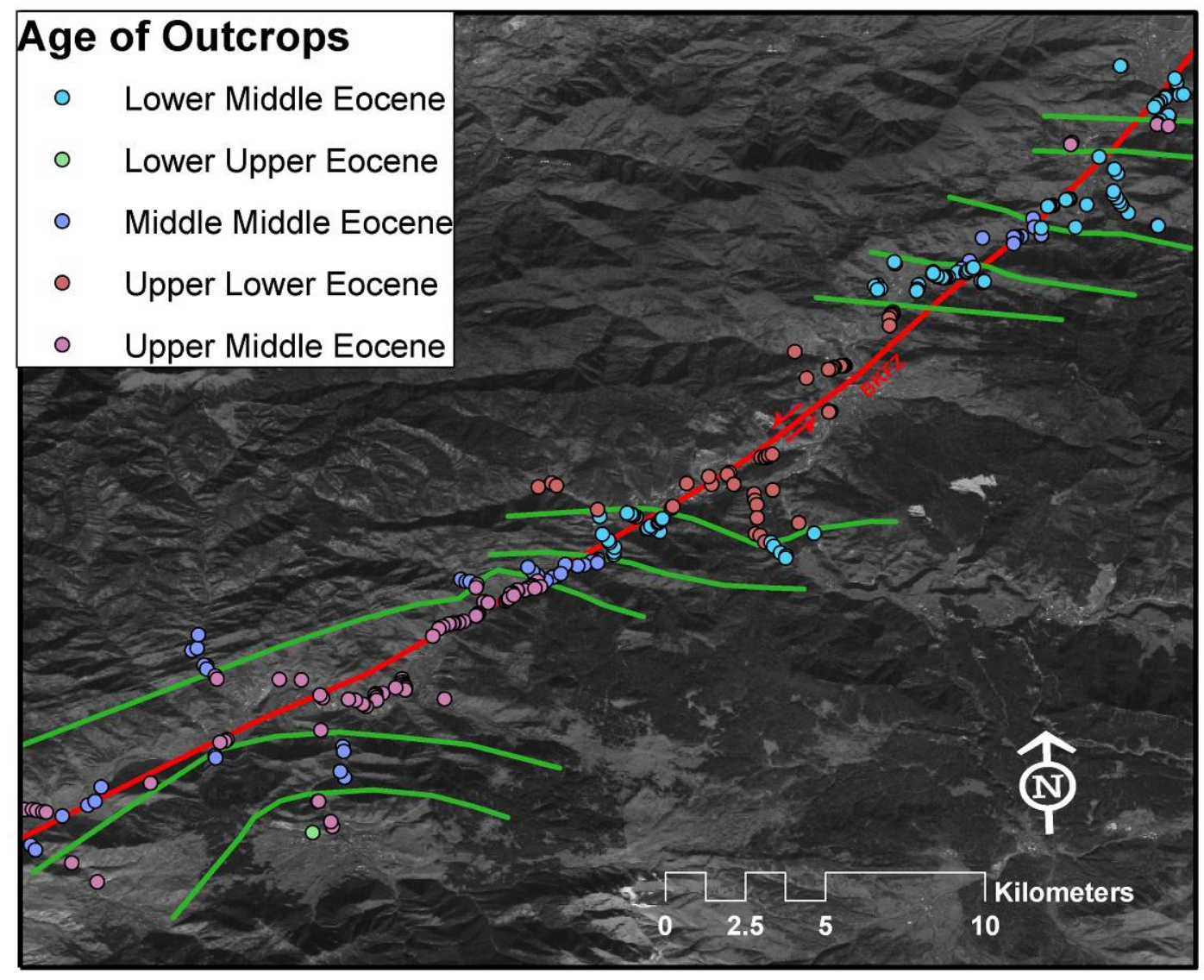

Figure 3-10: Map of lithologic contacts by age. There was no sinistral displacement of lithologic contacts. The field data confirm the Soviet geologic map shown in Figure 12. 

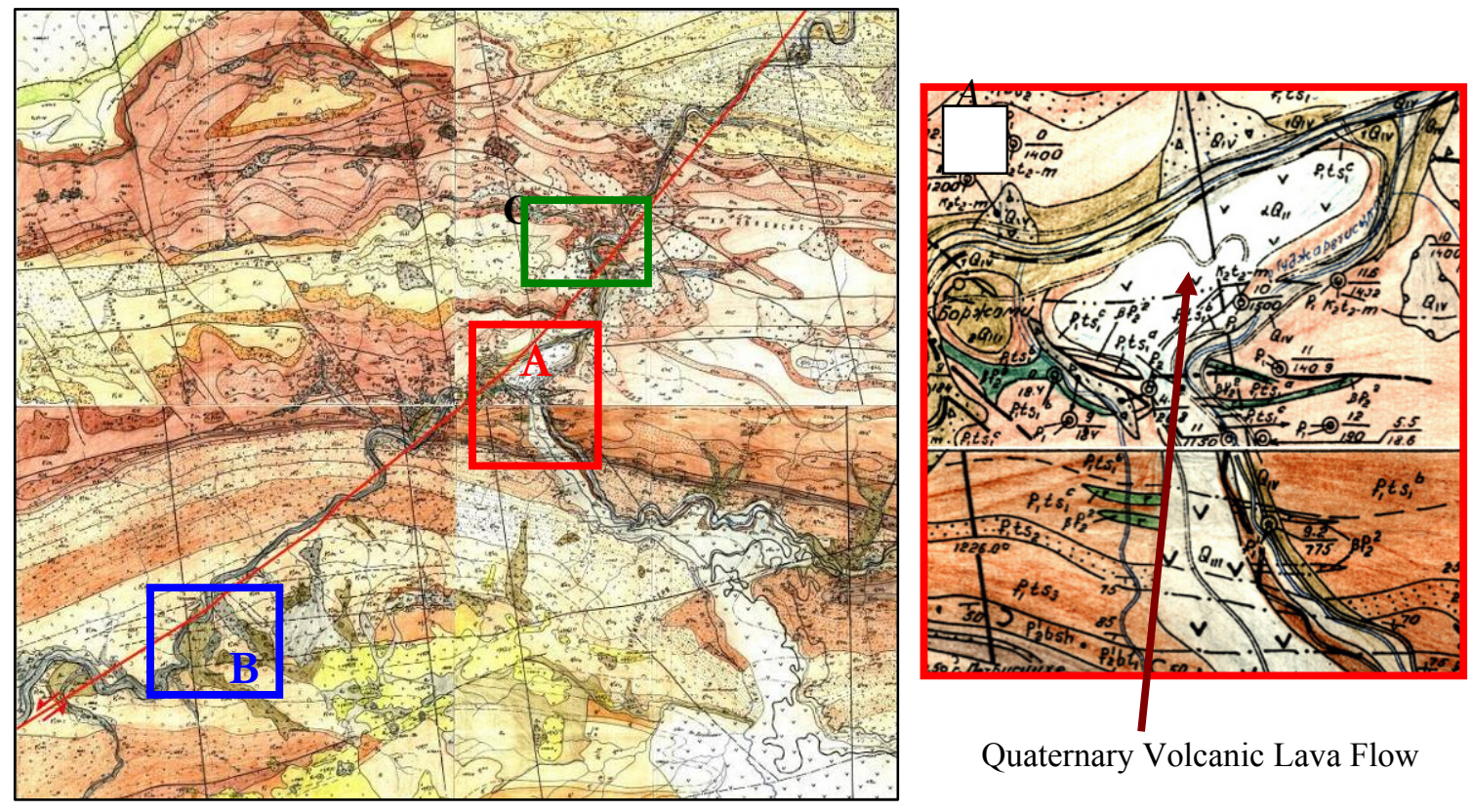

Quaternary Volcanic Lava Flow

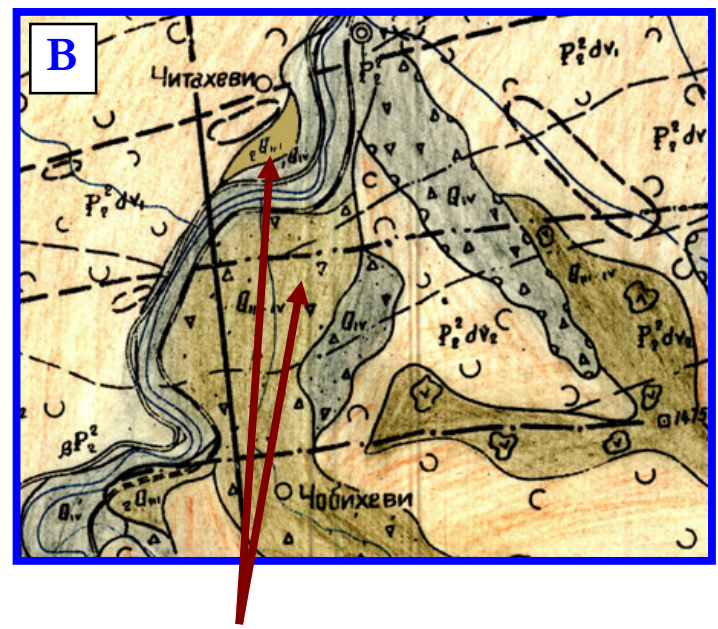

Quaternary Rhyolitic Fluvial Deposits

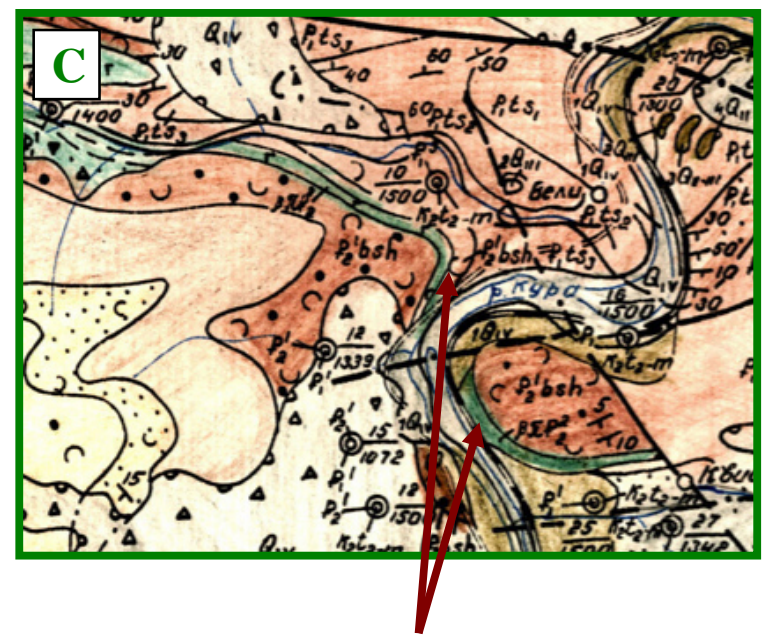

Upper Eocene Diabase Sill

Figure 3-11 - Mosaic of Soviet 1:25,000 scale geologic maps of the Borjomi Gorge. The Soviet maps show no displacement across the strike of the BKFZ. The green and blue boxes $(\mathrm{B}, \mathrm{C})$ highlight localized marker layers. The red box (A) highlights the Quaternary volcanic flow that indicates the Borjomi Gorge must be approximately 1 m.y. (Tutberidze, 2004). 


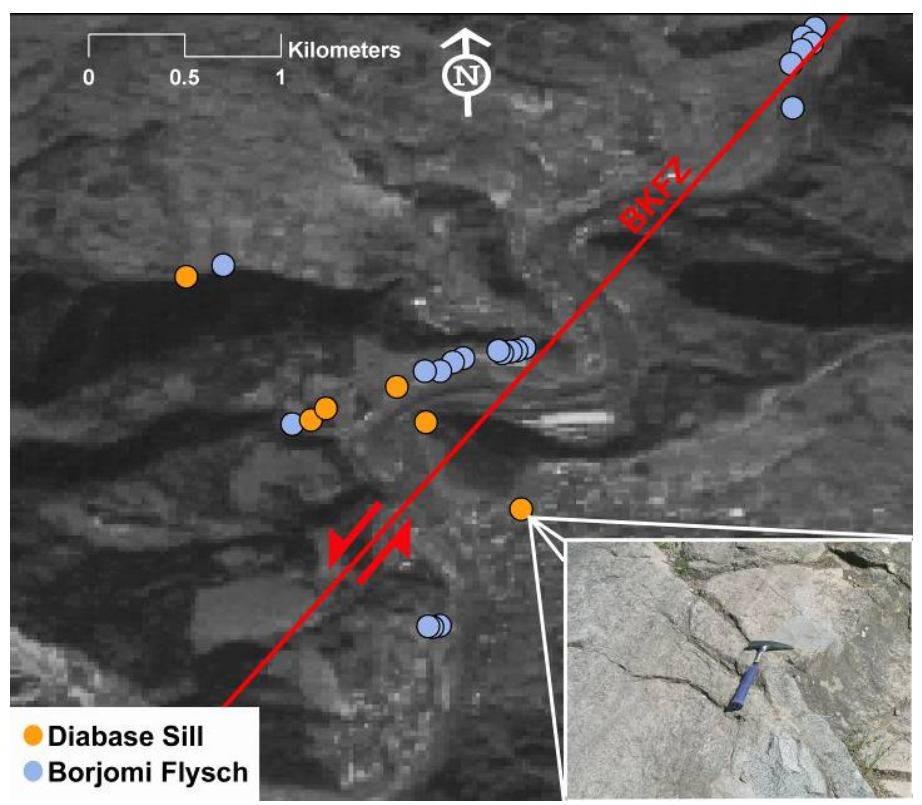

Figure 3-12: Upper Eocene diabase sill (red points). The maroon points are all Lower Eocene Borjomi Flysch. The diabase sill continued uninterrupted across the proposed fault. The location of this sill is shown by the green box in Figure 3-11.

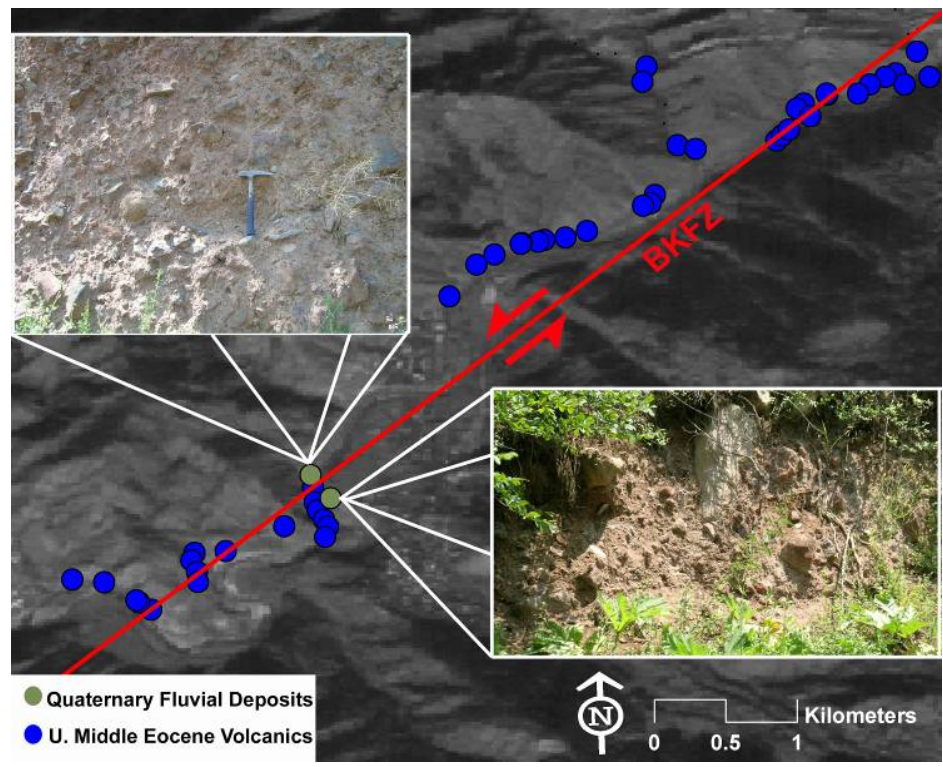

Figure 3-13: Quaternary rhyolitic fluvial deposits (red points). The blue points are all Upper Middle Eocene volcanics. The quaternary deposits were found only very locally on opposite sides of the proposed BKFZ, indicating that no displacement since deposition. The location of these deposits is shown by the blue box in Figure 3-12. 


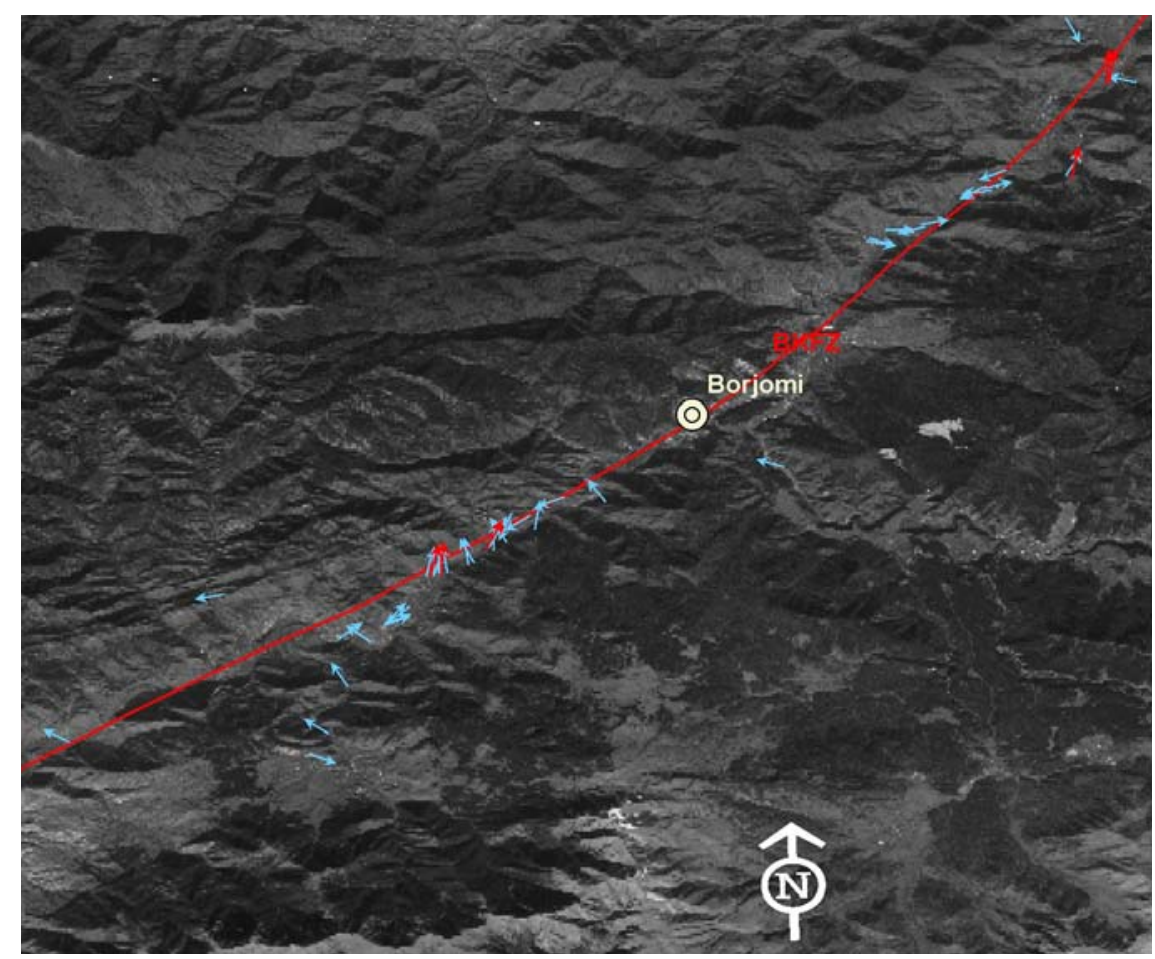

Figure 3-14: Orientation of slickenside planes and estimation of relative motion. The red arrows indicate points that have a strike and rake that coincide with the proposed BKFZ; the blue arrows do not. 


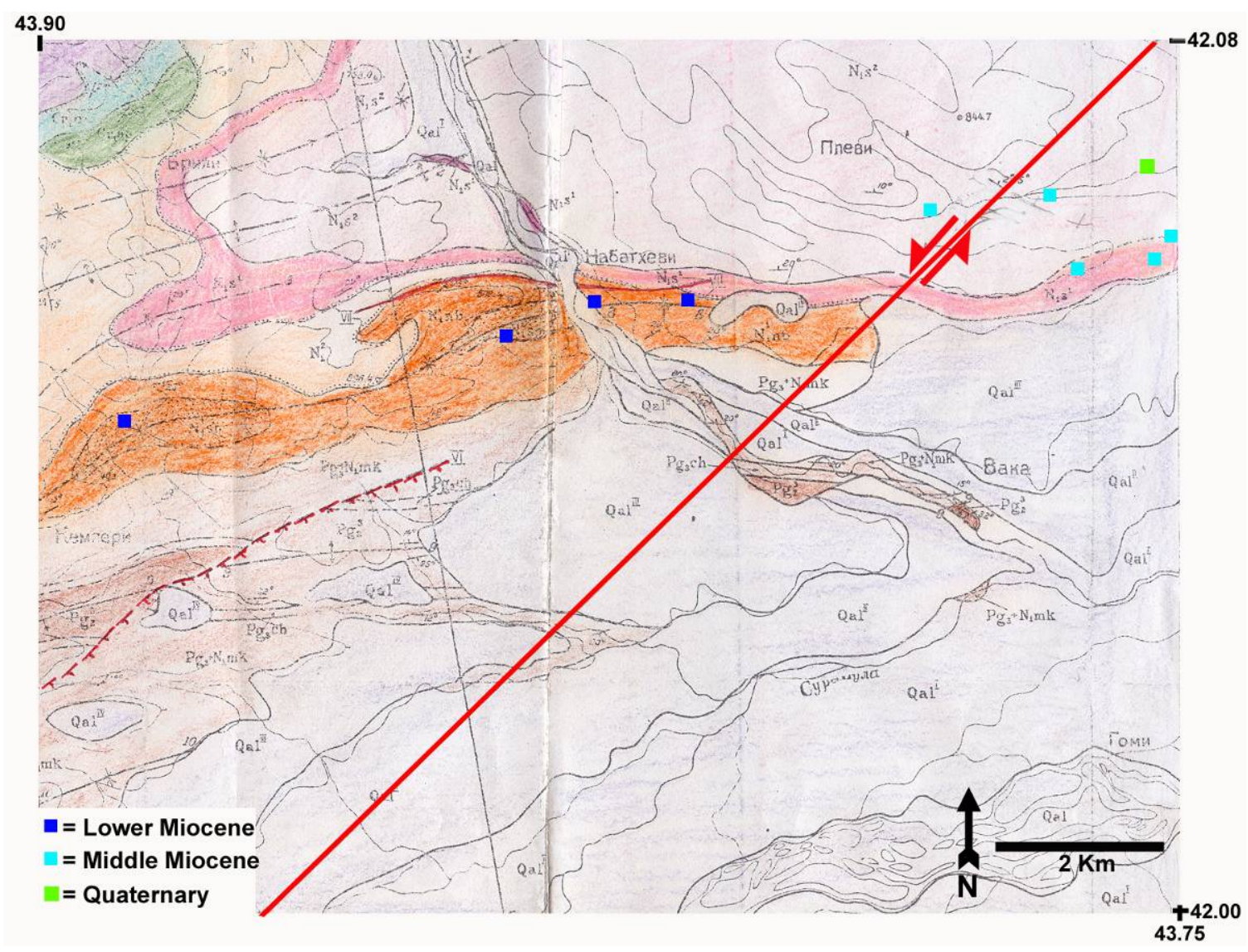

Figure 3-15: Points taken in the geologic fieldwork in the Kartli Basin. The points are plotted over the 1:50,000-scale geology map. The fieldwork corroborated the Soviet Era geologic map. Lower Miocene outcrops are depicted by dark blue squares, Middle Miocene by aqua squares and Quaternary by green squares. The red line shows the BKFZ. (Geologic map courtesy of S. Adamia) 


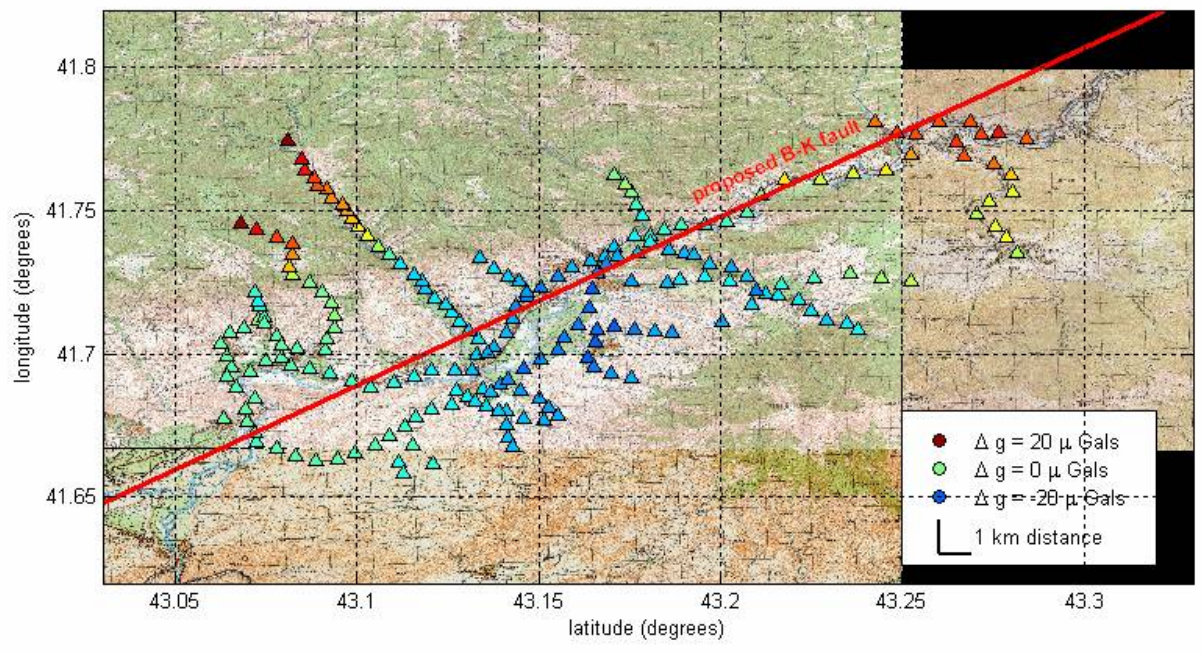

Figure 3-16: Results of the gravity survey. Stations were taken every half kilometer along existing roads, and were generally confined to the region south of the head of the Borjomi gorge because of the difficulty of the terrain. Red lines are faults in the regional tectonic model; the heavy line running SW to NE is the proposed Borjomi-Kazbegi fault. 


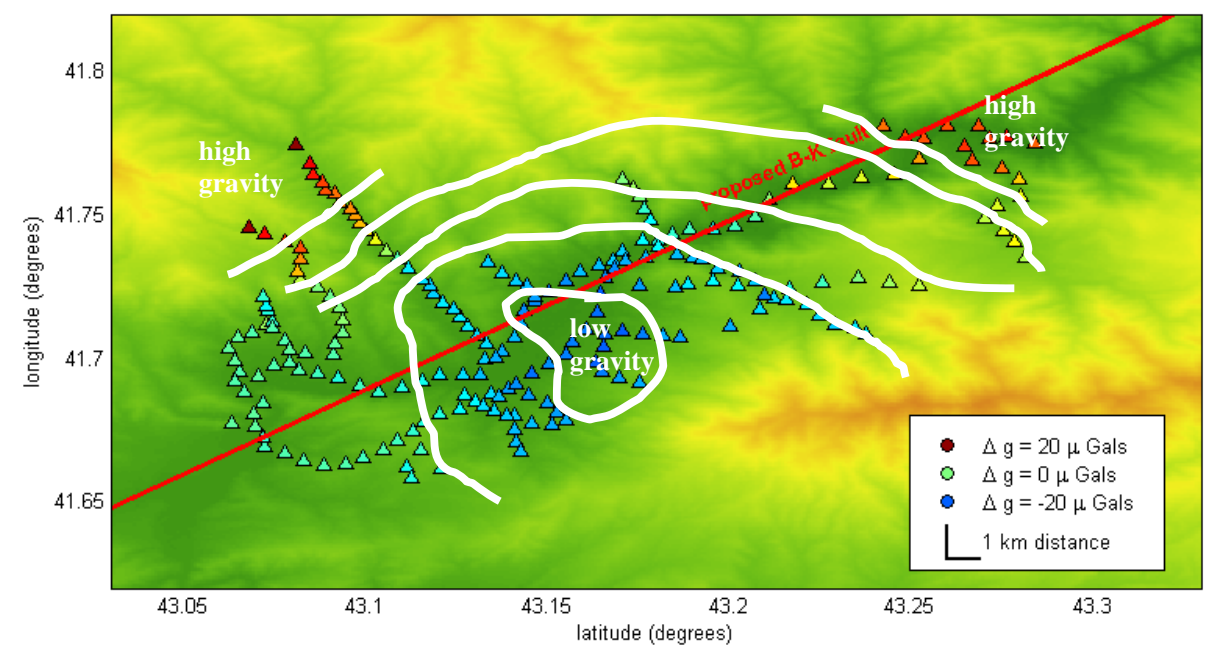

Figure 3-17: The same gravity data as shown in Figure 3-16, overlying the topography of the region. Heavy white lines show a rough interpretation of the data. A gravity low underlies the valley at the head of the gorge, with gravity highs to the north. This pattern does not show any correspondence to the proposed faultline.

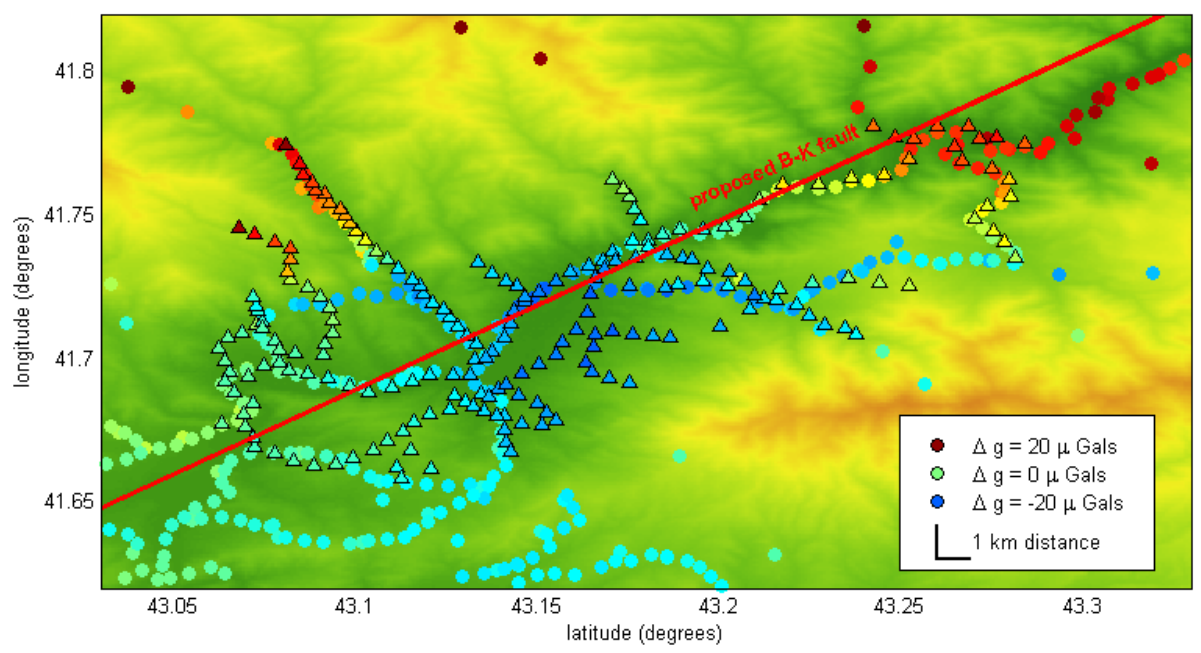

Figure 3-18: The 2005 gravity data (triangles) overlying data collected during the Soviet era (circles). The fieldwork details of the Soviet Data have been lost, so it is impossible to know the methodology and precise accuracy of the data, but it does corroborate the 2005 data. 


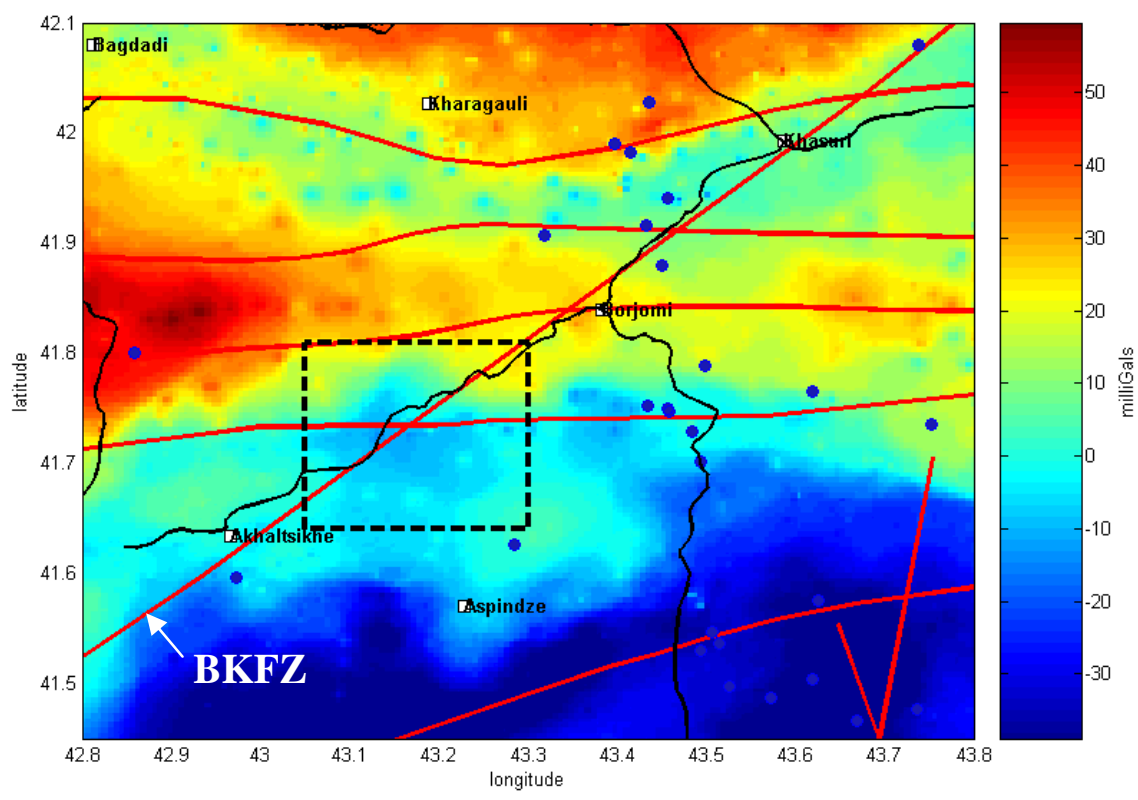

Figure 3-19: Soviet era aerogravity survey, with the 2005 field area shown in the black box. 


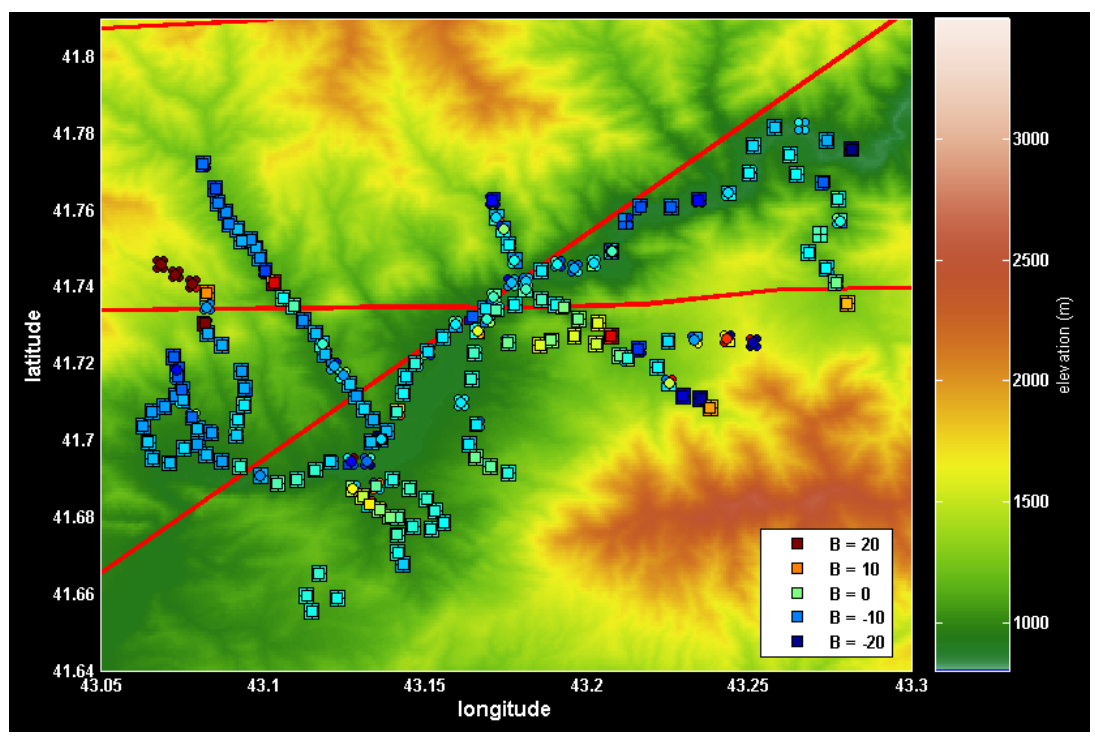

Figure 3-20: the results of magnetic survey. This data was deemed inconclusive due to excessive error caused by a low quality polarizing fluid widespread amount of noise due to the frequent and unavoidable proximity of metallic fences and other debris. 


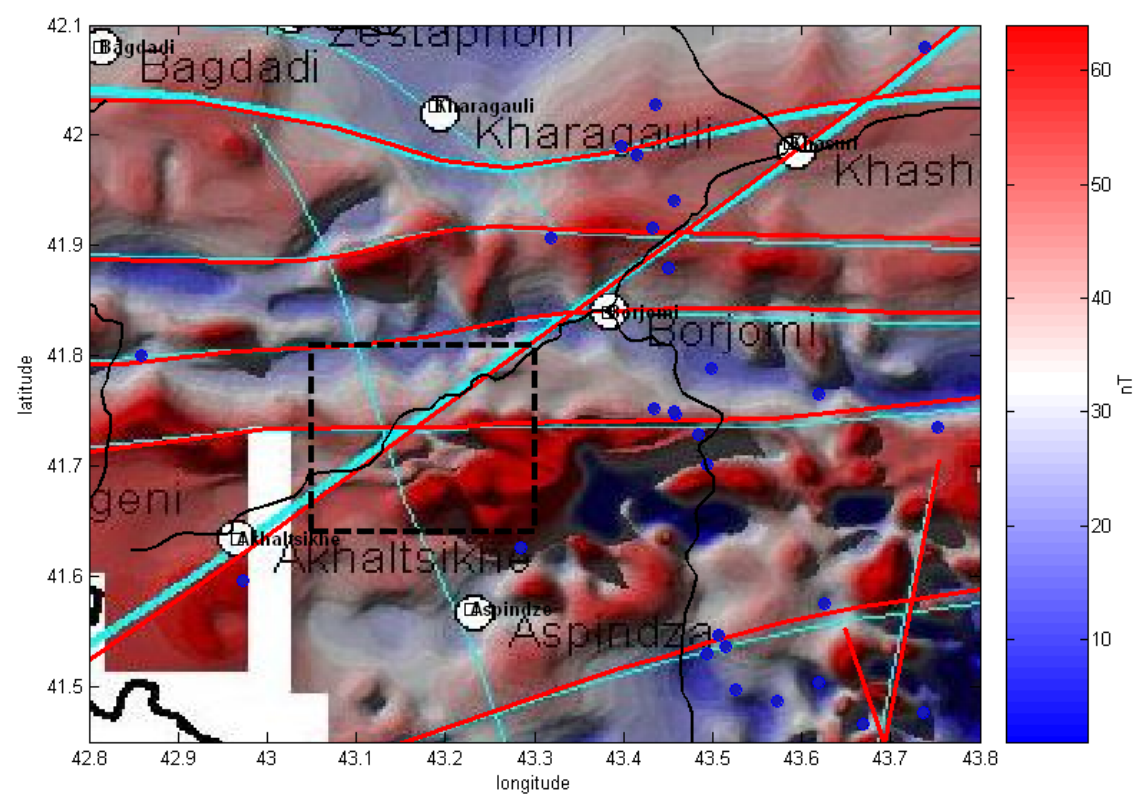

Figure 3-21: Soviet era aeromagnetic survey, with the 2005 field area shown in the black box. 

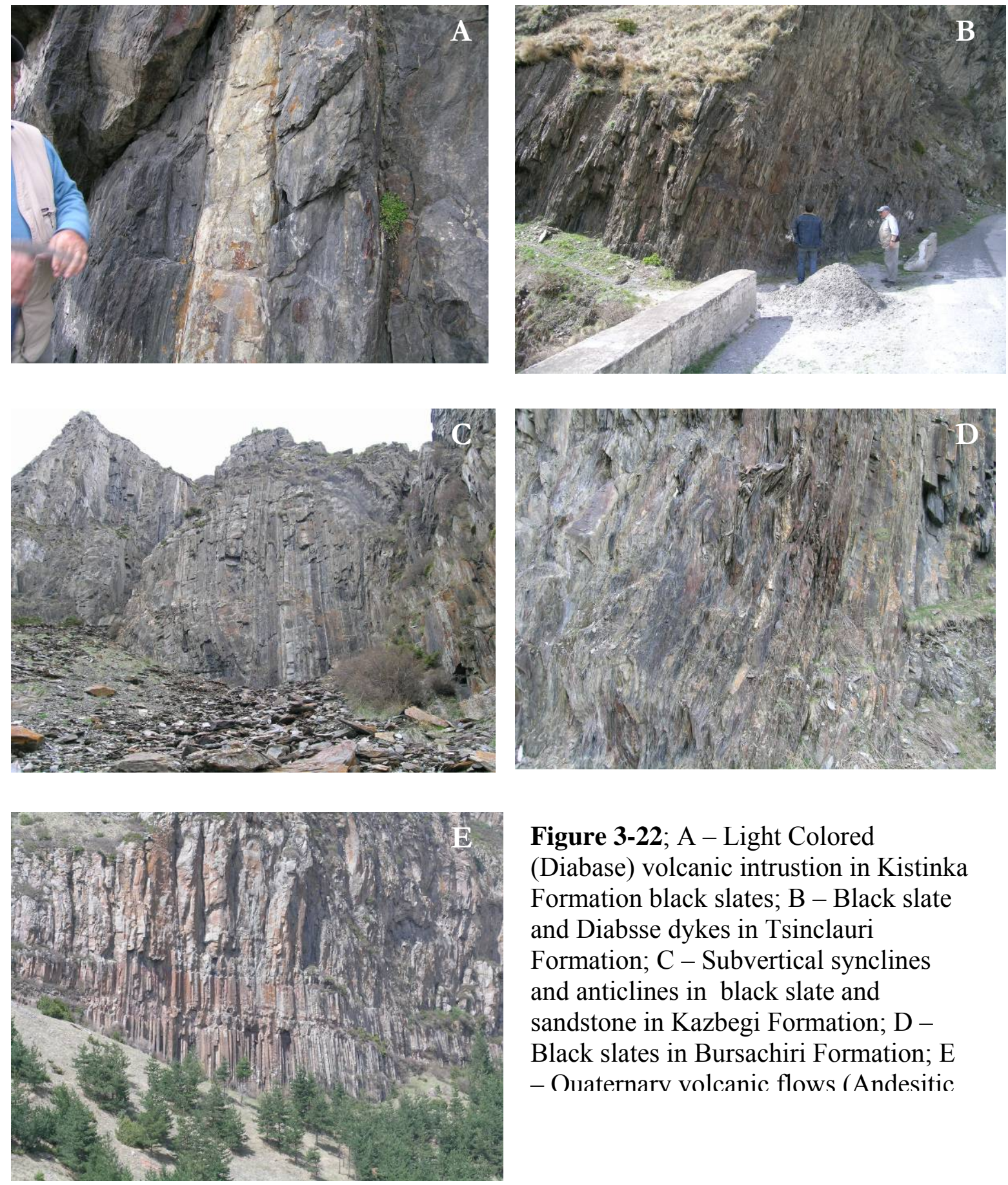

Figure 3-22; A - Light Colored (Diabase) volcanic intrustion in Kistinka Formation black slates; B - Black slate and Diabsse dykes in Tsinclauri Formation; C - Subvertical synclines and anticlines in black slate and sandstone in Kazbegi Formation; D Black slates in Bursachiri Formation; E - Ouaternarv volcanic flows ( Andesitic 


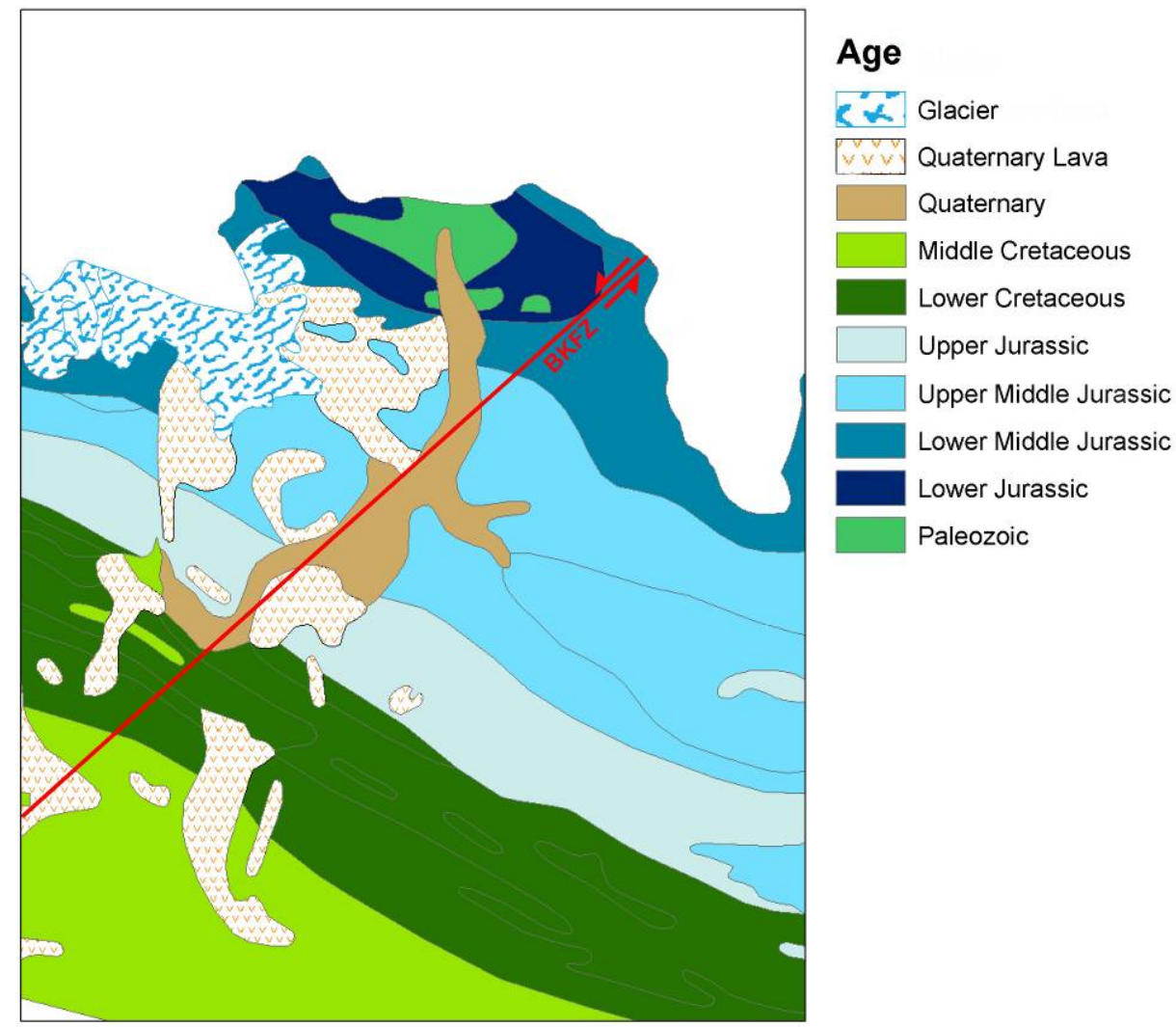

Figure 3-23: Geologic map of the Kazbegi Area. The map shows that the geologic layers follow an E-W trend and are not displaced by the BKFZ.. 


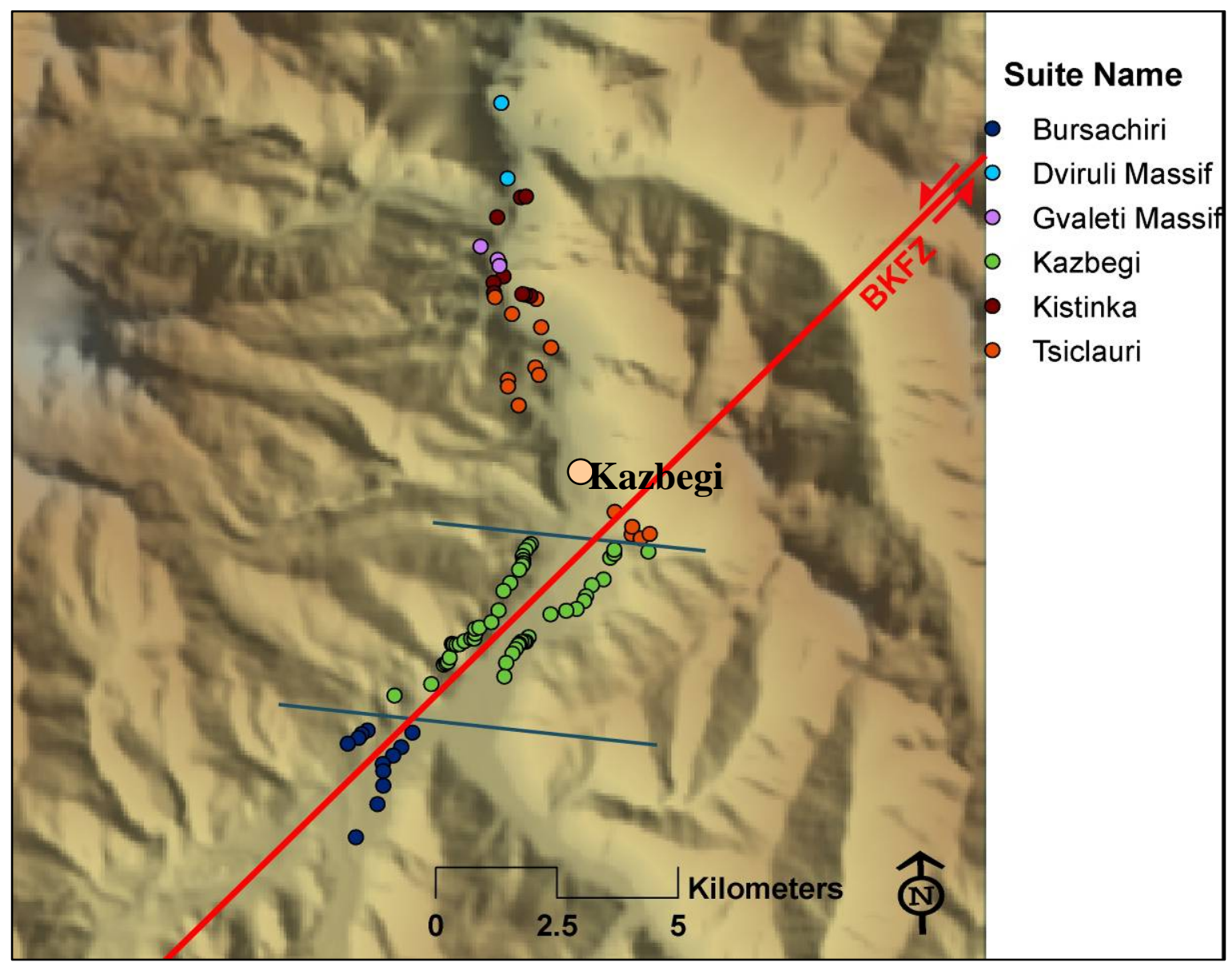

Figure 3-24: Map of geologic stations showing no sinistral offset of the BKFZ. The map shows outcrops of the basement massifs (Gvaleti and Dviruli) as well as the Lower Jurassic sedimentary suites. The blue lines indicates the lateral continuity of the lithologic changes in the Terek River valley. 


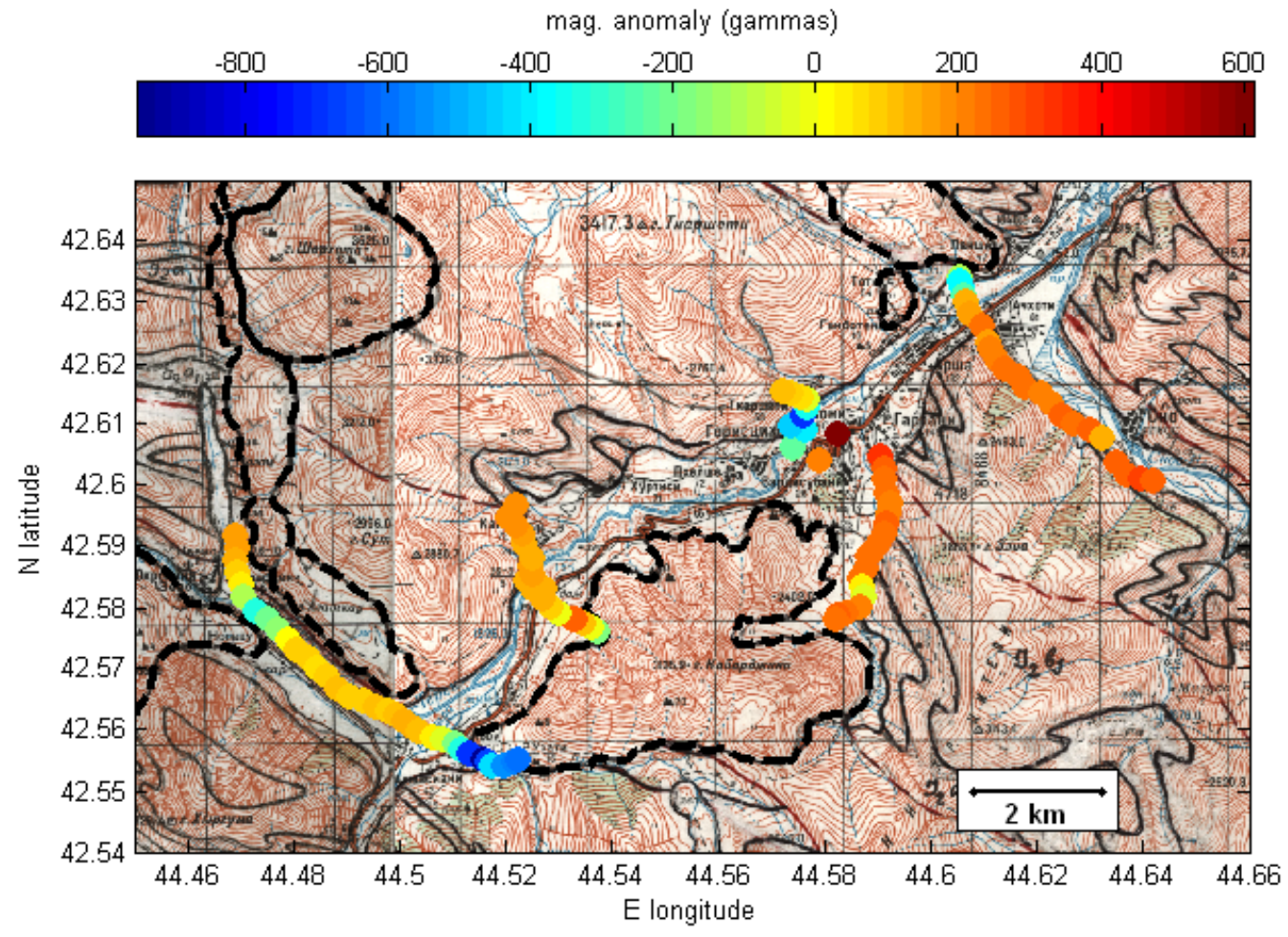

Figure 3-25: Results of magnetic survey in the Kazbegi region of the Greater Caucasus. Heavy dashed black lines show the location of volcanic outcrops. The magnetic data showed negative anomalies near the volcanics, but no obvious dependency on the proposed BKFZ, which runs SW-NE along the valley.. 


\title{
Chapter 4: Crustal Structure of Caucasus and Surrounding Regions from P-wave Travel-time Tomography
}

\begin{abstract}
A 3-D P-wave velocity model is developed for the crust and uppermost mantle of Caucasus and the surrounding area by applying the tomography method of Sun and Toksöz (2006) using 300,000 high-quality P-wave first arrivals from 43,000 events between 1964 and 2005. This tomographic method can accommodate velocity discontinuities such as the Moho in addition to smooth velocity variations. The spatial resolution is $1^{\circ} \times 1^{\circ}$ in the horizontal direction and $10 \mathrm{~km}$ in depth. The velocity images of the upper crust correspond well with the surface geology. Beneath the southern Caucasus high velocity anomalies are found in the middle crust and low velocity anomalies are found in the uppermost mantle. Relatively low Pn velocities are located under the Lesser Caucasus, eastern Turkey, and northern Iran. Higher Pn velocities occur under the eastern portion of the Black Sea and the southern Caspian Sea, and also extend into the eastern edge of Azerbaijan. Tomographic model significantly reduces the traveltime residuals.
\end{abstract}




\subsection{Introduction}

The structure of the Caucasus mountain region and surrounding areas is primarily controlled by the collision and continuing convergence of the Arabian and Eurasian plates. The Arabian and Eurasian plates collided in the early Miocene after the NeoTethys Sea was subducted beneath Eurasia, and several tectonic features were formed as a result of the collision. The Caucasus Mountains, an orogenic belt that was uplifted as a consequence of the collision, have with elevations over $5 \mathrm{~km}$ above sea level and extend $1300 \mathrm{~km}$ in a NW-SE direction between the Black Sea and southern Caspian Sea basins. The Rioni Basin in the west and the Kura Basin in the east dissect this orogenic belt into two parts separating the Greater Caucasus in the north from the Lesser Caucasus in the south. These two basins are separated by the Transcaucasian Dzirula Massif in the middle. The Greater Caucasus ranges consist mostly of Paleozoic metasedimentary rocks and granitoids, Jurassic sediments, Mesozoic and Cenozoic volcanics (Adamia et al., 1977; Khain, 1984). The Lesser Caucasus ranges consist of Paleozoic granitoidmetamorphic basement overlain unconformably by shelf carbonates of PaleozoicTriassic age. They also contain ophiolite mélange lithologies of the Sevan-Akera and the Vedi suture zones. The basement rocks and the ophiolites are overlain by the extensive volcano-sedimentary sequence of Late Eocene-Early Miocene age (Khain, 1984; Koçyiğit et al., 2001).

The collision of the Arabian and Eurasian plates also played a part in the formation of the Black Sea and southern Caspian Sea Basins. The Black Sea is generally thought to have a basement of oceanic crust that is overlain with $10-20 \mathrm{~km}$ of sediment. Similarly, the basement of the Southern Caspian Sea basin has geophysical attributes like 
that of thick oceanic crust and is overlain by $\sim 20 \mathrm{~km}$ of sedimentary cover (Mangino and Priestley, 1998). The continuing convergence in the region continues to affect the deformation, tectonic structure, and seismicity of the region.

In general folding, thrusting and high angle reverse faulting is the most dominant form of deformation in the Caucasus region. The fault mechanism solutions for the earthquakes indicate predominantly thrust events with NW-SE trending fault planes (McKenzie, 1972; Jackson and McKenzie, 1984; Jackson, 1992; Cisternas and Philip, 1997; Jackson et al., 2002). Recent GPS measurements provide valuable information regarding the active deformation of the Caucasus region (Reilinger et al., 1997; McClusky et al., 2000; Reilinger et al., 2006). Estimates of the overall N-S shortening across both the Greater and Lesser Caucasus are approximately $10+/-2 \mathrm{~mm} / \mathrm{yr}$ of which $\sim 60 \%$ is accommodated by the greater Caucasus (Reilinger et al., 1997; McClusky et al., 2000). These studies indicate, however, that there is little internal shortening within the Greater Caucasus and that the present rate of shortening across the Caucasus cannot account for all the observed strain in the region.

The seismicity of the region is predominantly controlled by the continuing convergence of the Arabian and Eurasian plates. A number of large (6.5-7 Magnitude) earthquakes have occurred in the Caucasus within the last decade. For example, the Spitak Earthquake of December 7, $1988(\mathrm{Ms}=6.9)$ occurred in the Lesser Caucasus region, along the Pambak-Sevan thrust fault at a depth of $10 \mathrm{~km}$, and the Racha earthquake of April 29, 1991 (Ms=7.0) occurred in the Greater Caucasus region along a thrust zone between the Greater Caucasus and the Dzirula Massif at a depth between 3 and $10 \mathrm{~km}$ (Triep et al., 1995). Overall, large magnitude earthquakes are mainly located 
near the margins of the range, and seismicity is higher to the east of the Caucasus mountains (Jackson, 1992) and most earthquakes are located between 10-40 km depth in the crust. The interior of the Southern Caspian Sea is relatively aseismic, though intermediate depth earthquakes with depths of $\sim 80 \mathrm{~km}$ are located in north of the southern Caspian Basin suggesting northward underthrusting beneath the middle Caspian region (Jackson et al., 2002).

A number of studies have examined the crust and upper most mantle structure across the Arabian-Eurasian collision zone. Large scale Pn wave tomographic studies show large variations in crustal thickness and upper most mantle velocities within the Caucasus region. Slow Pn velocities $(\leq 8 \mathrm{~km} / \mathrm{s})$ were found beneath the Anatolian plateau and the Greater Caucasus, and very low Pn velocities $(\leq 7.8 \mathrm{~km} / \mathrm{s})$ were located beneath the Lesser Caucasus (Ritzwoller et al., 1998; Hearn and Ni, 1994; Al-Lazki et al., 2004). Relatively fast Pn velocities $(>8.0 \mathrm{~km} / \mathrm{s})$ were found beneath the southern Caspian and Black Sea basins (Al Lazki et al., 2004; Ritzwoller er al., 2002). Regional scale surface wave and gravity studies suggest a thickened crust beneath the Caucasus mountains, with maximum Moho depths of $\sim 60 \mathrm{~km}$ (Ruppel and McNutt, 1990).

A good resolution 3-D velocity model of Caucasus remains to be done to provide accurate travel-times for reliable determination of earthquake locations. Large-scale models obtained by the teleseismic tomography technique generally cannot resolve vertical variations in the shallow structure. Regional models can be combined in order to cover a large area, but such models cannot guarantee smooth and consistent transitions between different regions. The large database of high-quality recorded arrival-times in 
the study area provides an unprecedented opportunity to determine a detailed 3-D crustal structure under the region. Therefore, we introduce a method that constructs a 3-D Pvelocity model for the whole Caucasus area based on observed travel-time data.

We first construct a Pn model following Hearn's (1996) method and obtain a $1^{\circ} \times$ $1^{\circ}$ layered 3-D model using the adaptive moving window (AMW) method (Sun et al. 2004). We use an extensive catalog of forty years of earthquake arrival-time data between 1964 and 2005. These models are used as starting models of the 3-D tomography.

\subsection{Pn Tomography}

Following Hearn's (1996) approach and computation method, Pn travel-time residuals are inverted for the lateral velocity variation and anisotropy within the mantle lid. Within the epicentral distances considered in this study, the Pn ray paths can be modeled as refracted rays traveling along the Moho discontinuity. The variation of seismic velocity within the uppermost mantle is parameterized by subdividing the surface of the uppermost mantle in a 2-D grid of square cells with dimensions of $30 \mathrm{~km}$ by 30 $\mathrm{km}$. The Pn travel-time residuals are described as the sum of three time terms:

$$
t_{i j}=a_{i}+b_{j}+\sum d_{i j k}\left(s_{k}+A_{k} \cos 2 \varphi+B_{k} \sin 2 \varphi\right)
$$

where tij is the travel time residual for the ray from event $\mathrm{j}$ to station $\mathrm{i}$; ai is the static delay for station i, depending on the crust thickness and velocity beneath the station; bj is the static delay for event $\mathrm{j}$, not only depending on the crust thickness and velocity beneath the event, but also on the event focal depth; dijk is the distance traveled by ray ij in mantle cell k; sk is the slowness perturbation for cell k; Ak and Bk are the anisotropic coefficients for cell $\mathrm{k}$; and $\varphi$ is the back azimuth angle. The unknown 
quantities in the equation are ai, bj, sk, Ak and Bk. As a first approximation, seismic anisotropy in the mantle is assumed to be described by a $2 \varphi$ azimuthal variation. The magnitude of anisotropy for cell $\mathrm{k}$ is given by and the azimuthal angle $\theta$ of the fast direction of Pn propagation is given by $1 / 2 \arctan (\mathrm{Bk} / \mathrm{Ak})$. The sum is calculated over all cells through which the ray travels in the uppermost mantle. Further details of the tomography technique used here can be found in Hearn (1996). A set of Laplacian damping equations regularizes the solution, and two damping constants are separately applied to the unknown slowness and anisotropic coefficients. A proper pair of damping constants is chosen to balance the error size and the resolution width. In this approach the trade-off between velocity and anisotropy is a crucial issue, which has been examined by using different combinations of damping parameters for both velocity and anisotropy. In this study the main features of the velocity and anisotropy fields are observed to be significantly stable, even though the extent of the velocity anomalies and the amount of anisotropy vary slightly for different combinations of the damping constants.

Figures 4-1 through 4-5 show preliminary results of applying this tomography method to the CauSIN time picks database, which has been recently extended to include data from local Turkish networks. Figure 4-1 shows the ray paths used in the tomography; there are 41,682 Pn rays from 5,465 events to 245 stations. Figure 4-2 shows preliminary results of 3D tomography for lateral variations in Pn velocity. Areas of thicker continental crust throughout the central Caucasus show lower velocities, while the oceanic crust under the Black and Caspian Seas show higher velocities. The region of higher velocity under the eastern portion of Azerbaijan is most likely due to high velocities in the oceanic crust under the south Caspian Sea. Poor coverage of ray paths in 
this part of the study area has resulted in smearing the feature toward the west. Similarly, the high velocity in the northern part of the image is most likely from a basin structure north of the Greater Caucasus. Figure 4-3 shows station delays for Pn travel-times, while Figure 4-4 shows event delays for Pn travel-times. Finally, Figure 4-5 shows travel-time residuals before and after inversion. The standard deviation of travel-time residuals is reduced from $1.28 \mathrm{sec}$ to $0.92 \mathrm{sec}$.

This tomography result will improve the coverage once data is received from our colleagues in Azerbaijan. We will also extend the study region past the Caspian Sea into central Asia when this dataset is joined with data being collected for the CASRI project in Central Asia.

\subsection{3-D Tomography}

For this 3-D tomographic study, we use the earthquake phase data (first P-wave arrivals) from January 1964 to December 2005 in the study area. There are 43,000 earthquakes, 350 stations, and 300,000 ray paths in the Caucasus and the surrounding area in this database. Figures 4-6 and 4-7 show earthquake epicenters, the stations, and the ray paths.

Given that the ray coverage is denser in some areas and redundant calculation is involved, we adopted the method described below to assemble the best set of the earthquake data. The study area is divided into parallelepipedic blocks with a spatial size of $10 \mathrm{~km}$ (northing) $\times 10 \mathrm{~km}$ (easting) $\times 2 \mathrm{~km}($ depth $)$. Among the earthquakes within each block, we only select the event with the greatest number of first P-wave arrivals and the smallest hypocentral location uncertainty. As a result, our final dataset contains 
24,000 events with more than 200,000 ray paths. The final ray coverage has a better (more uniform) distribution in the study area, and it is therefore more appropriate for tomographic study than the original dataset. Since most aftershocks occur in similar locations with smaller magnitudes and tend to produce larger reading errors for the phase arrivals than the main shocks, the final dataset contains the least number of aftershocks.

The input and output 3-D models are represented by velocity perturbations relative to an averaged 1-D reference model in the study area. Even though the traveltimes are calculated based on 3-D models, the 1-D reference model significantly influences the final result of the tomographic study because of the linearization process taken in the tomography. An inappropriate initial reference model may not only affect the quality of the three dimensional images by introducing artifacts, but it may also influence the confidence calculations by underestimating the uncertainties of the results (Yu et al., 2003; Kissling et al., 1994). We inverted the arrival-time data in our selected dataset for a 1-D velocity model representing the whole study area by minimizing the root mean square (rms) error of the travel-times. Finally we obtained the 1-D model which gave the best fit to the observed data. We used this averaged 1-D model as the reference velocity model for our tomographic inversions.

The discontinuities represent known geological boundaries such as the Conrad and the Moho discontinuities. Previous studies were able to map the Moho discontinuity in the study area and revealed its significant lateral depth variations (Ritzwoller et al., 1998; Hearn and Ni, 1994; Al-Lazki et al., 2004). The Conrad discontinuity is clear only in some regions of the study area, and therefore we only incorporate the Moho discontinuity in this study. The input geometry of the Moho discontinuity was compiled 
following Sun et al. (2004) and Sun and Toksöz (2006). The Moho depths range from 15 $\mathrm{km}$ to $45 \mathrm{~km}$. All the depths are referenced to sea level.

We applied the tomographic method of Zhao et al. (1992) for determining the crustal and uppermost mantle velocity structures in the Caucasus and the surrounding area. Zhao's method, described in detail in several papers (Zhao et al., 1992, 1994; Zhao, 2001; Sun and Toksöz, 2006), allows 3-D velocity variations everywhere in the model and can accommodate velocity discontinuities. The velocity structure is discretized using a 3-D grid. The velocity perturbation at each point is calculated by linearly interpolating the velocity perturbations at the eight surrounding (adjacent) grid nodes. Velocity perturbations at grid nodes are the unknown parameters for the inversion procedure. To calculate travel-times and ray paths accurately and rapidly, the pseudo-bending technique (Um and Thurber, 1987) and Snell's law are used iteratively. Station elevations are taken into account as station corrections when an averaged $4 \mathrm{~km} / \mathrm{s}$ crustal velocity model was used. The LSQR algorithm (Paige and Saunders, 1982) with a damping regularization is used to solve the large and sparse system of equations. The nonlinear tomographic problem is solved by iteratively conducting linear inversions. At each iteration, perturbations to hypocentral parameters and velocity structure are determined simultaneously.

From the checkerboard resolution analyses, we adopt a grid spacing of $1^{\circ}$ in the horizontal direction, and $10 \mathrm{~km}$ in depth (Figure 4-8). We add grid nodes at depths of 1 $\mathrm{km}, 2 \mathrm{~km}, 5 \mathrm{~km}$, and $7 \mathrm{~km}$ to discretize the sediment layer. We chose a damping value of 25.0 from the tradeoff curve between the travel-time residuals and the model variance by considering the balance between the reduction of travel-time residuals and the 
smoothness of the 3-D velocity model obtained (Eberhart-Phillips, 1986). For the inversion with a damping parameter of 20.0 , the rms travel-time residual is reduced from $0.89 \mathrm{~s}$ to $0.54 \mathrm{~s}$, and the variance reduction is $60 \%$ between the initial and final 3-D models. Over $70 \%$ of the rays have residuals smaller than $0.45 \mathrm{~s}$ after the inversion. The rms travel-time residual is about $1.1 \mathrm{~s}$ if the 1-D reference model is used to calculate the travel-times. The variance reduction is about $63 \%$ between the final 3-D model and the averaged 1-D model.

The distribution of hit counts (number of rays passing through each grid node) for each layer shows that most parts of the study area are well sampled by the rays. Intuitively, given such extensive ray coverage, we expect a model with high spatial resolution. We will examine the model resolution in a systematic manner later.

The Moho variations are shown in Figure 4-9. Vertical cross sections of the velocity images along the profiles denoted in Figure 4-10 are shown in Figures 4-11 and 4-12. The tomographic images are shown in areas with hit counts greater than 5 .

Before analyzing the results of the tomographic inversion, we perform tests with synthetic data to evaluate the resolution of the tomographic image. We calculate a set of travel-time delays by tracing the corresponding rays through a synthetic structure such as checkerboard, then we invert the synthetic data for the velocity structure, and finally we compare the inversion result with the initial synthetic model. To make a checkerboard velocity model, we assign $\pm 3 \%$ velocity perturbations to the 3 -D grid nodes (Figure 4 13). Random errors from a normal distribution with a standard deviation of $0.1 \mathrm{~s}$ are added to the synthetic travel-times calculated from the synthetic models. Leveque et al. (1993) showed that in some cases small structures in a checkerboard test can be retrieved 
effectively while large structures are poorly imaged. To test for such behavior in our tomographic study, we conduct checkerboard tests with different grid spacings of $1^{\circ}, 2^{\circ}$, $4^{\circ}$, and $8^{\circ}$.

Our tests show the $1^{\circ}$ velocity model is best recovered in most study areas. This correlates well with hit count distribution patterns. From these resolution tests, we infer that for the Caucasus and the surrounding area, the tomographic images obtained have a spatial resolution of $1^{\circ}$ in the horizontal direction and $10 \mathrm{~km}$ in depth, and large-scale structures are well resolved.

\subsection{Results and Conclusions}

Strong P-wave velocity variations of more than $6 \%$ found in the study area indicate the existence of significant structural heterogeneities in the crust and uppermost mantle in this region. The Pn velocities shown in Fig. 2 have similar features to those obtained by Al-Lazki et al. (2004). High Pn velocities are dominant under eastern Azerbaijan/ southern Caspian and under eastern Black Sea. The extent of the anomalies require further confirmation. Because of the distribution of earthquake epicenters and stations, rays traversing the area are mostly NW-SE. It is important to ensure that there is no "smearing" along the dominant ray direction.

We are in the process of extending our data coverage to the south and east, which should improve the image of the high velocity zone under the south Caspian Sea. It will be more difficult to improve data coverage in the north, as there is very little seismicity north of the greater Caucasus and very few stations. We hope that combining this data with data from networks in the Central Asian countries (as part of the CASRI project) 
will be beneficial to the image quality in the northern and eastern region of the CauSIN study area.

The Moho discontinuity plays an important role in tomography. The importance of taking into account the Moho depth variations and other discontinuities in the tomographic inversion has also been demonstrated in the earlier studies of the Japan and Tonga subduction zones (Zhao et al., 1992, 1997), Southern Carpathians, Romania (Fan et al., 1998), and China (Sun and Toksöz, 2006). When the discontinuity topography is taken into account, ray paths and travel-times can be computed more accurately, and therefore a better tomographic result is expected. Sun and Toksöz (2006) shows that the final rms travel-time residual is $0.58 \mathrm{~s}$ for the inversion when the Moho topography is considered, $6 \%$ lower than the $0.62 \mathrm{~s} \mathrm{rms}$ residual with the flat Moho $(50 \mathrm{~km})$, the average Moho depth in China.

While the Moho depths are fixed as the initial model in our inversion, we conduct an inversion by allowing the Moho depths to change between $-5 \mathrm{~km}$ and $5 \mathrm{~km}$ of the initial model, and both Moho depths and velocities are unknowns in the inversion. The Moho depth difference is within $\pm 1 \mathrm{~km}$ and the Pn velocity difference is within $\pm 0.1 \mathrm{~km} / \mathrm{s}$ compared to the reference 3-D model. Along a vertical cross section, the final velocity difference is within $\pm 0.1 \mathrm{~km} / \mathrm{s}$ in the crust and uppermost mantle. The Moho depth difference along the Profile $\mathrm{E}$ is within $\pm 1 \mathrm{~km}$ throughout the cross section.

In summary, our velocity model shows the following features.

1 The seismic velocity images are characterized by block structures corresponding to geological features bounded by large fault zones. The trend of velocity anomalies is consistent with the trend of regional tectonics. 
2 Our tomographic imaging has revealed significant velocity heterogeneities in the middle and lower crust, some of which are consistent with those detected by deep seismic soundings and other geophysical investigations.

3 Pn velocities are high under eastern Azerbaijan/ southern Caspian and under eastern Black Sea.

4 Velocity heterogeneities below Moho at Caspian zone reflect the tectonic history and ongoing subduction.

Acknowledgements: Major contributors to this section include Youshun Sun and M. Nafi Toksöz (Earth Resources Laboratory, Massachusetts Institute of Technology). 


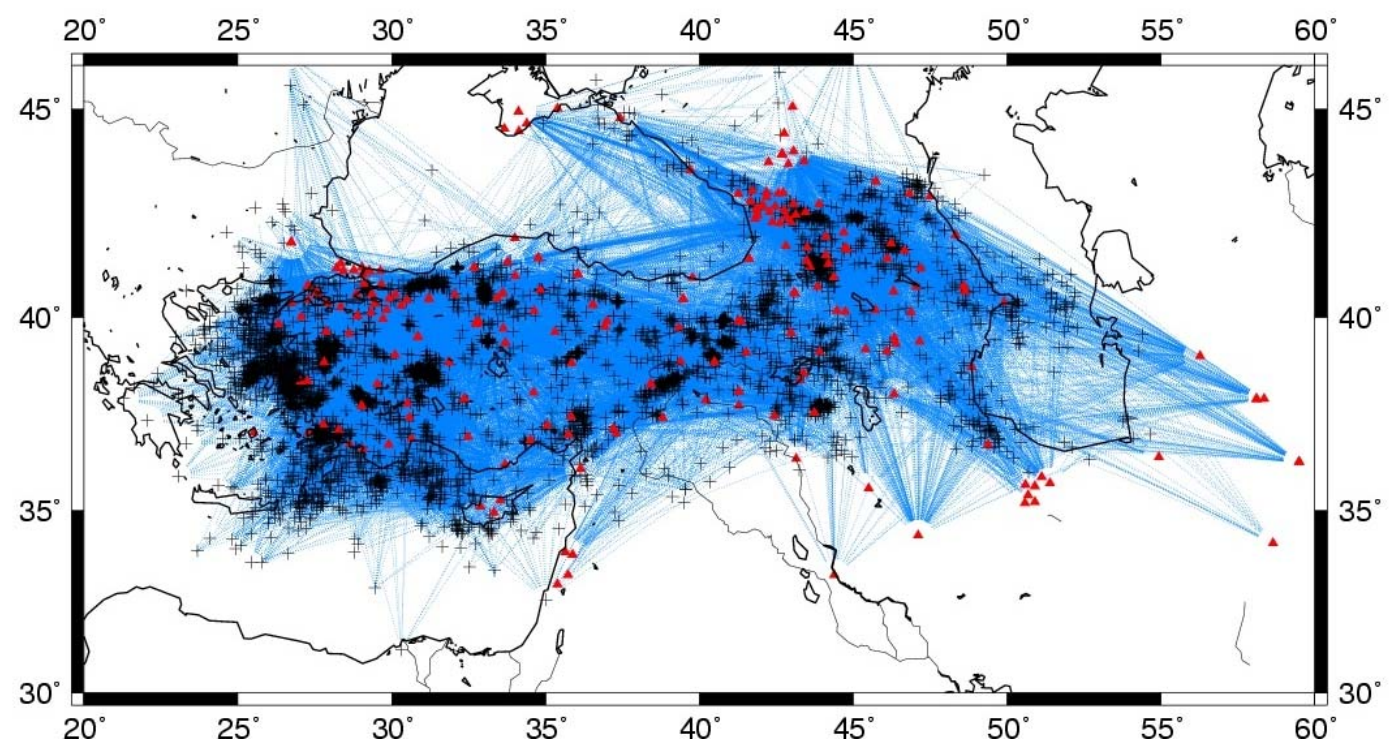

Figure 4-1: Ray paths for Pn travel times 41,682 Pn rays were obtained form 5,465 events (black cross) recorded by 245 stations (red triangle). 


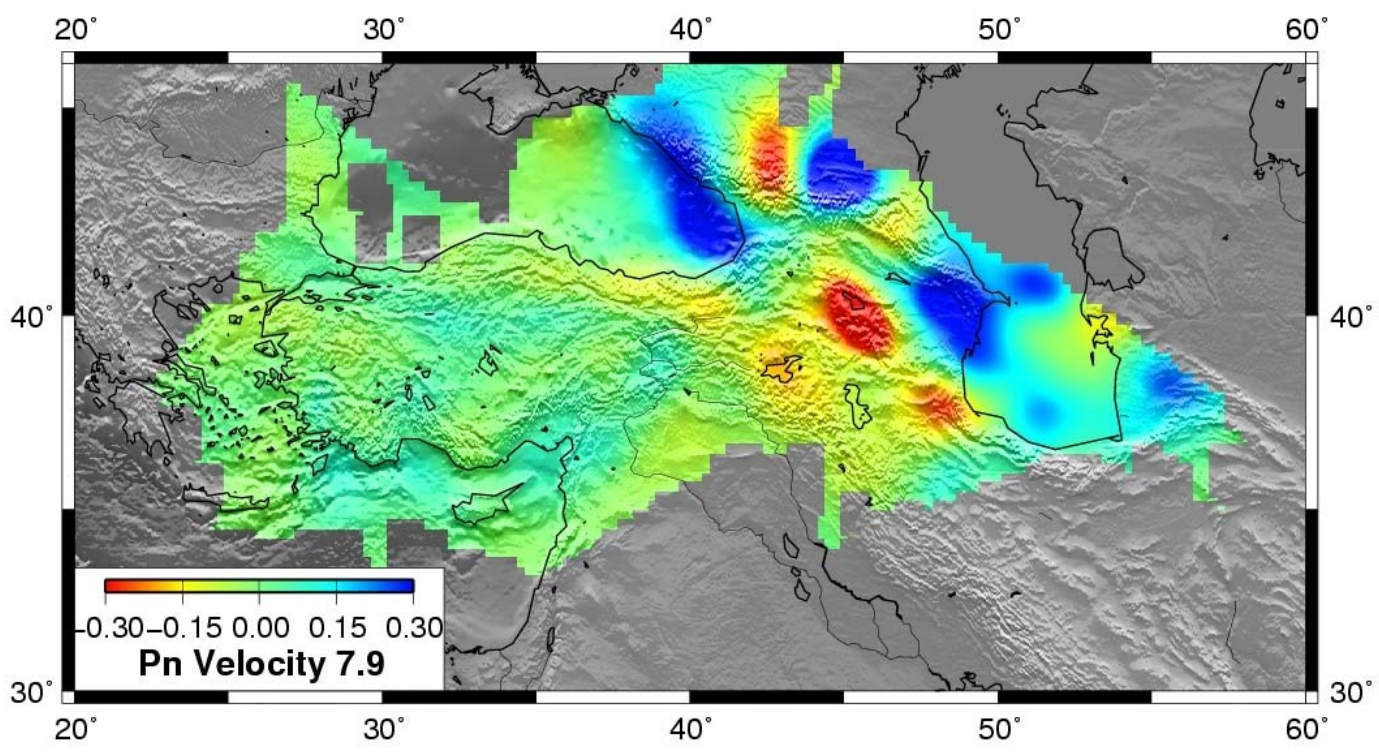

Figure 4-2: Imaged Pn velocity lateral variations Average Pn velocity is $7.9 \mathrm{~km} / \mathrm{s}$ and variation corresponds with color, red represents lower velocity than the average and blue denotes higher velocity. 


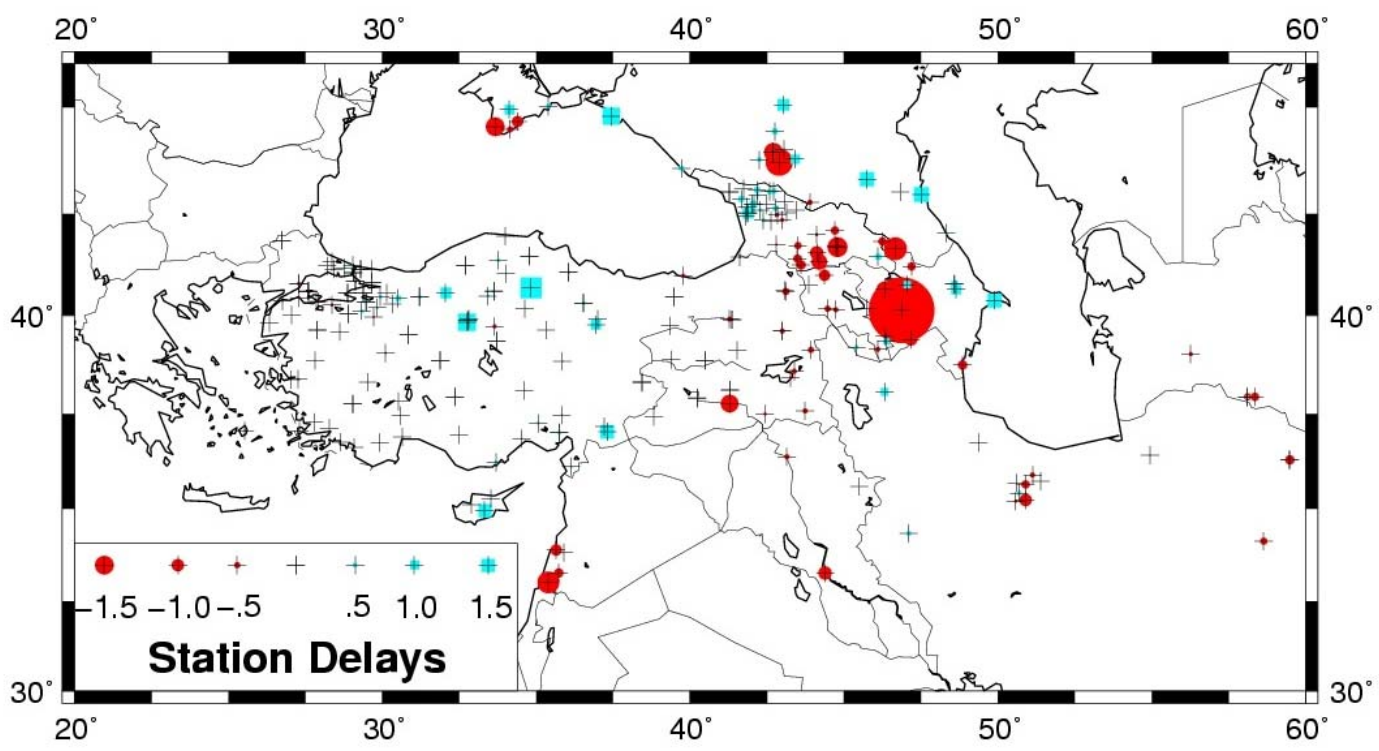

Figure 4-3: Station delays for Pn travel times Crosses represent stations. Circles indicate early arrival times and squares indicate late arrival times, with their size proportional to delay amount. 


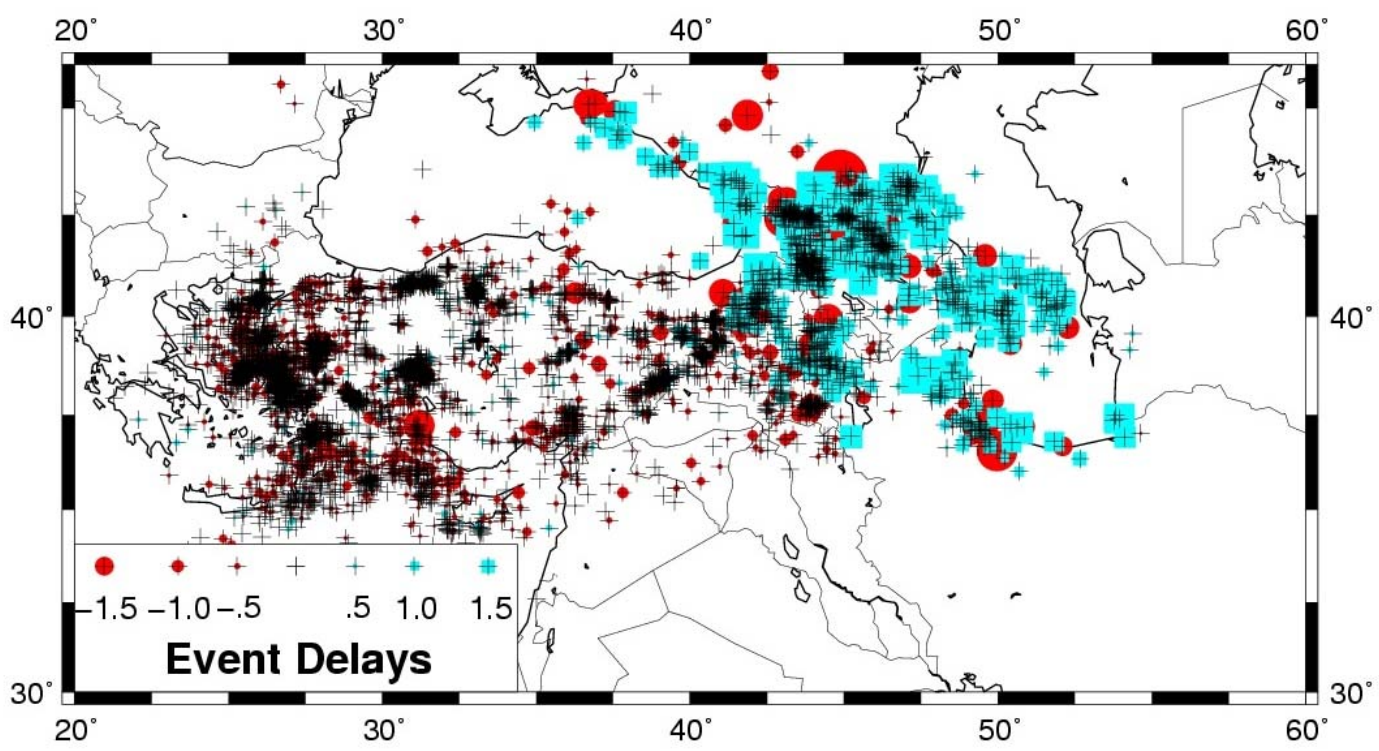

Figure 4-4: Event delays for Pn travel times Crosses represent events. Circles indicate early arrival times and squares indicate late arrival times, with their size proportional to delay amount. 

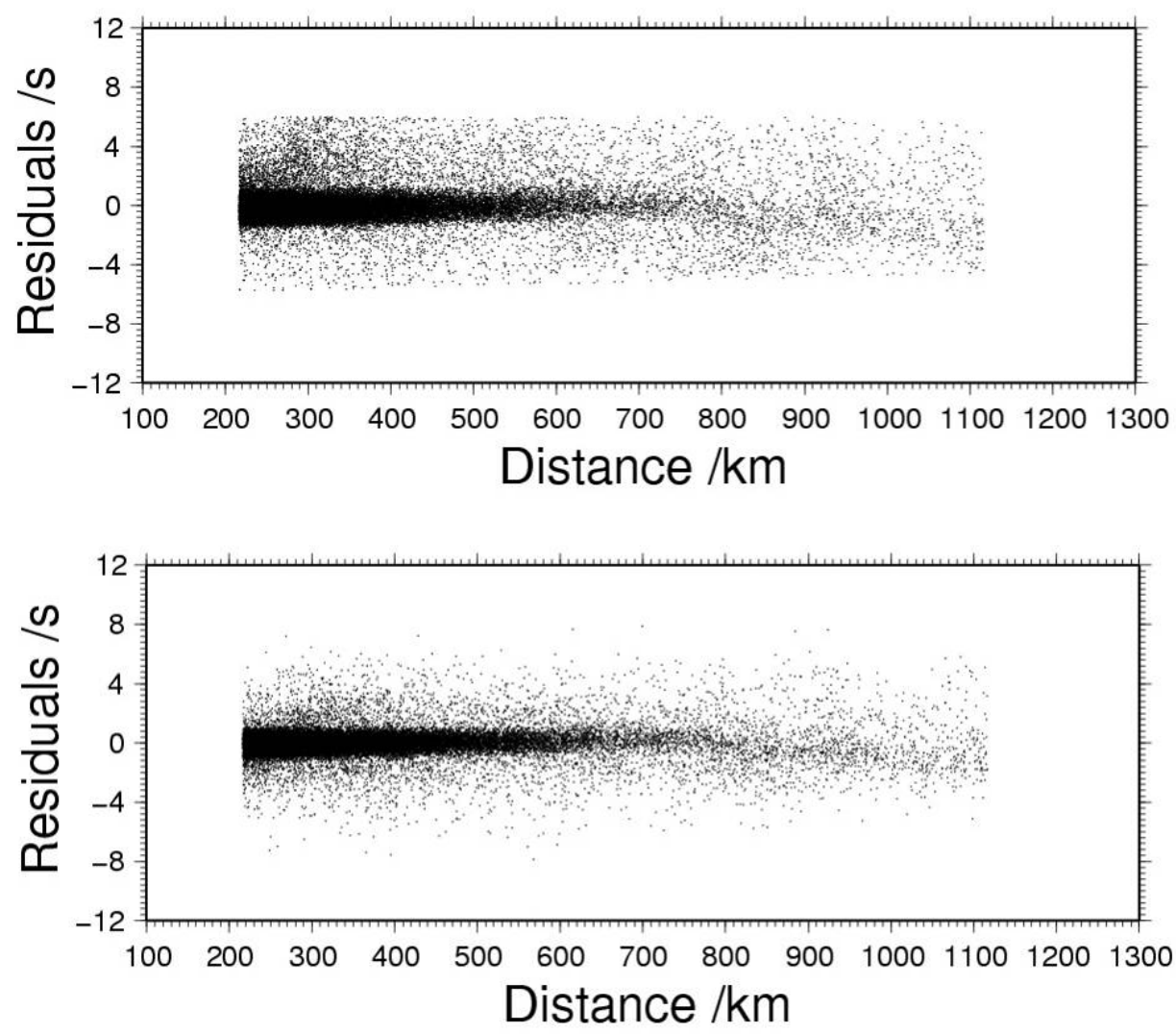

Figure 4-5: Travel time residuals before inversion (a) and after inversion (b). The standard deviation of travel time residuals decreased to $0.92 \mathrm{~s}$ from $1.28 \mathrm{~s}$. 


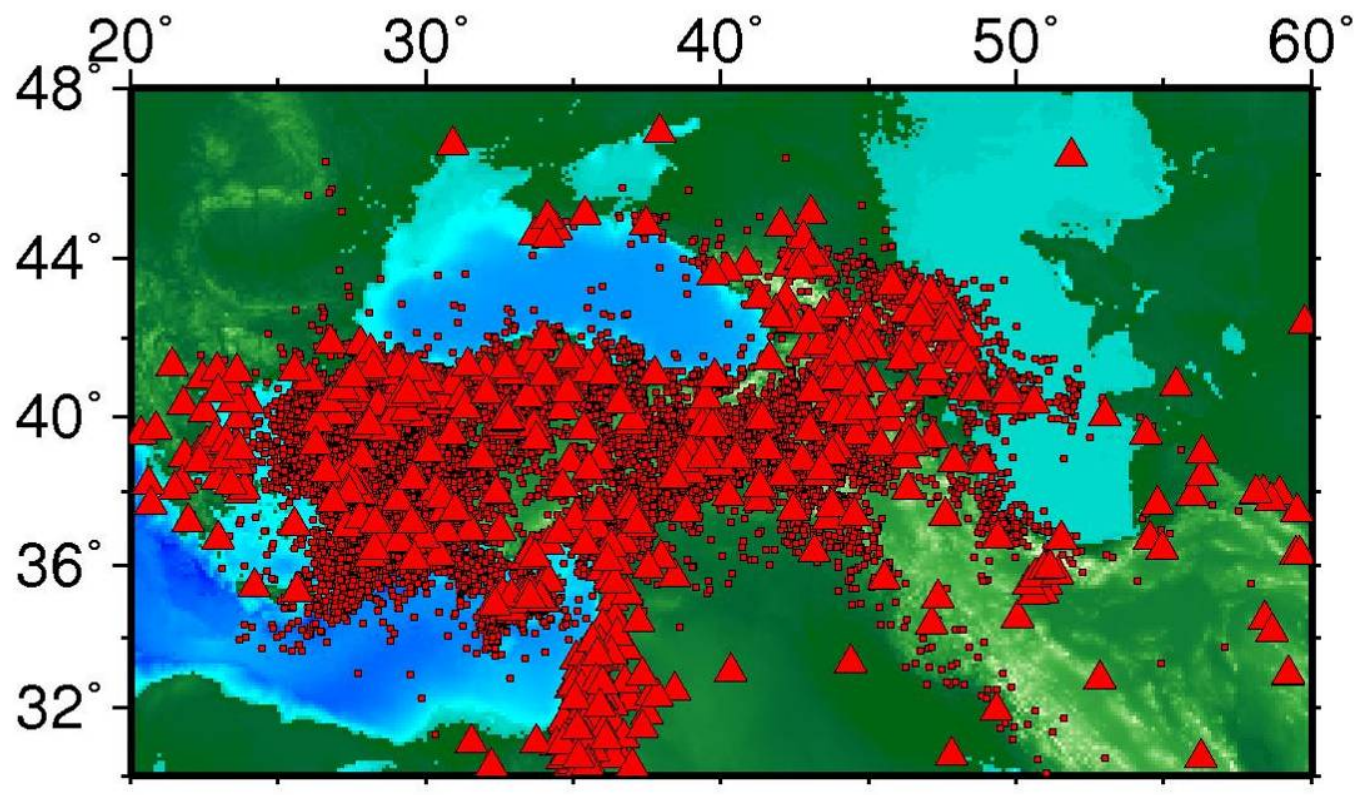

Figure 4-6: 43,000 earthquakes from January 1964 to December 2005 and 350 stations in Caucasus and the surrounding areas. Earthquake epicenters are shown in red dots and stations are shown in red triangles. 


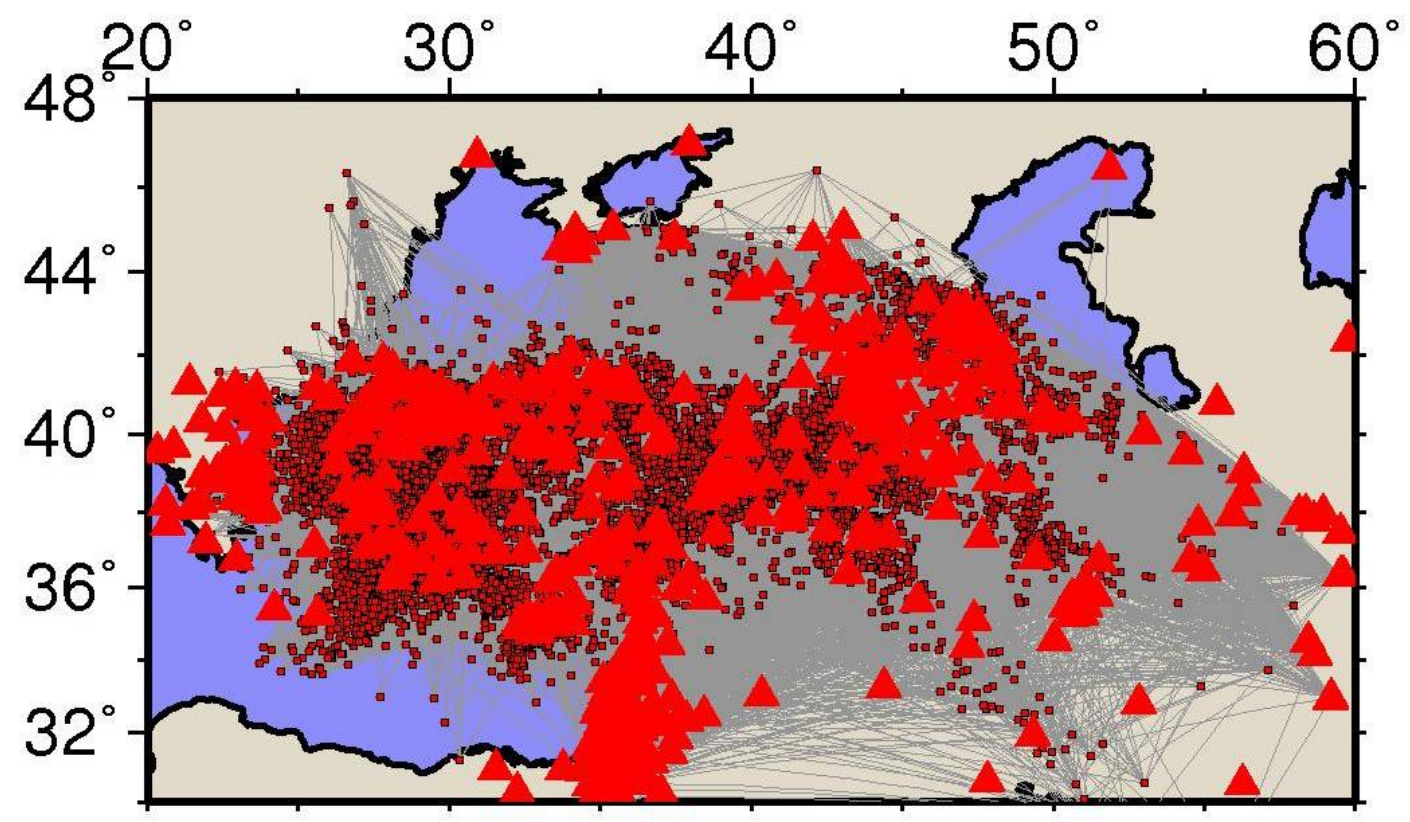

Figure 4-7: 43,000 earthquakes, 350 stations, and 300,000 ray paths in Caucasus and the surrounding areas. Earthquake epicenters are shown in black circles and stations are shown in red triangles. 


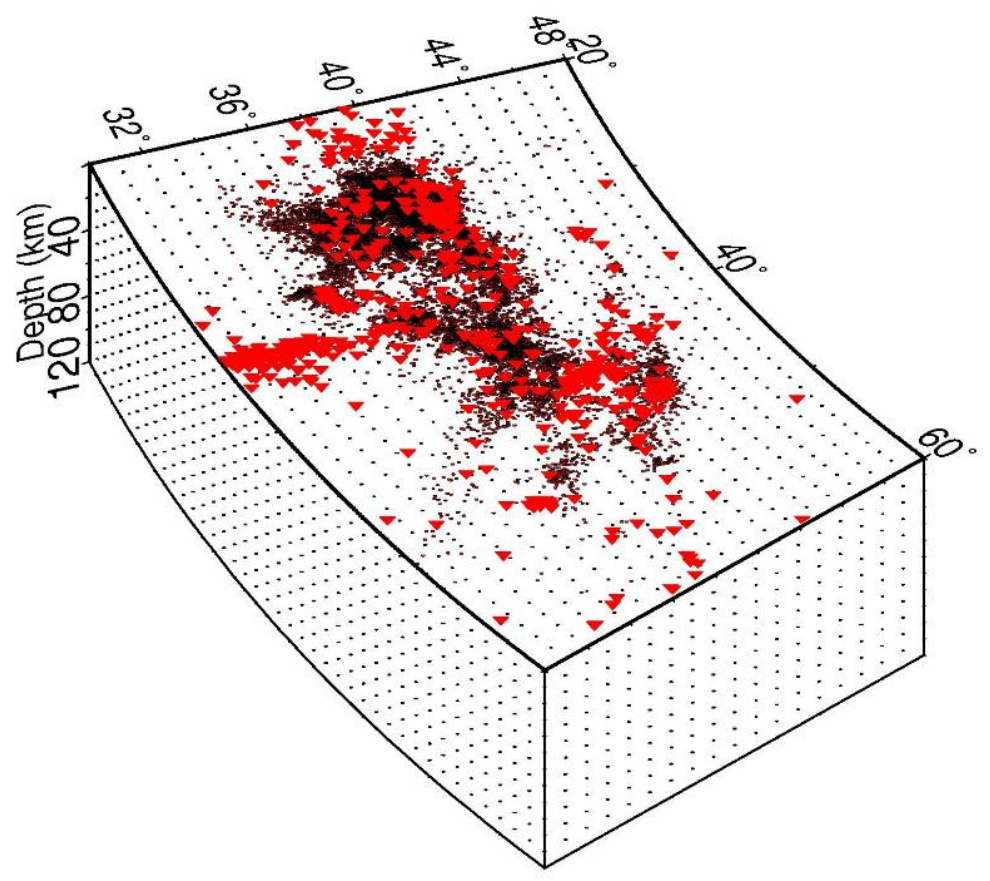

Figure 4-8: Three-dimensional configuration of the grid adopted in the present study. The resolution in horizontal direction is $1^{\circ}$. The resolution in vertical direction is $2 \mathrm{~km}$ (from surface to the depth of $10 \mathrm{~km}$ ) and 10 $\mathrm{km}$. 


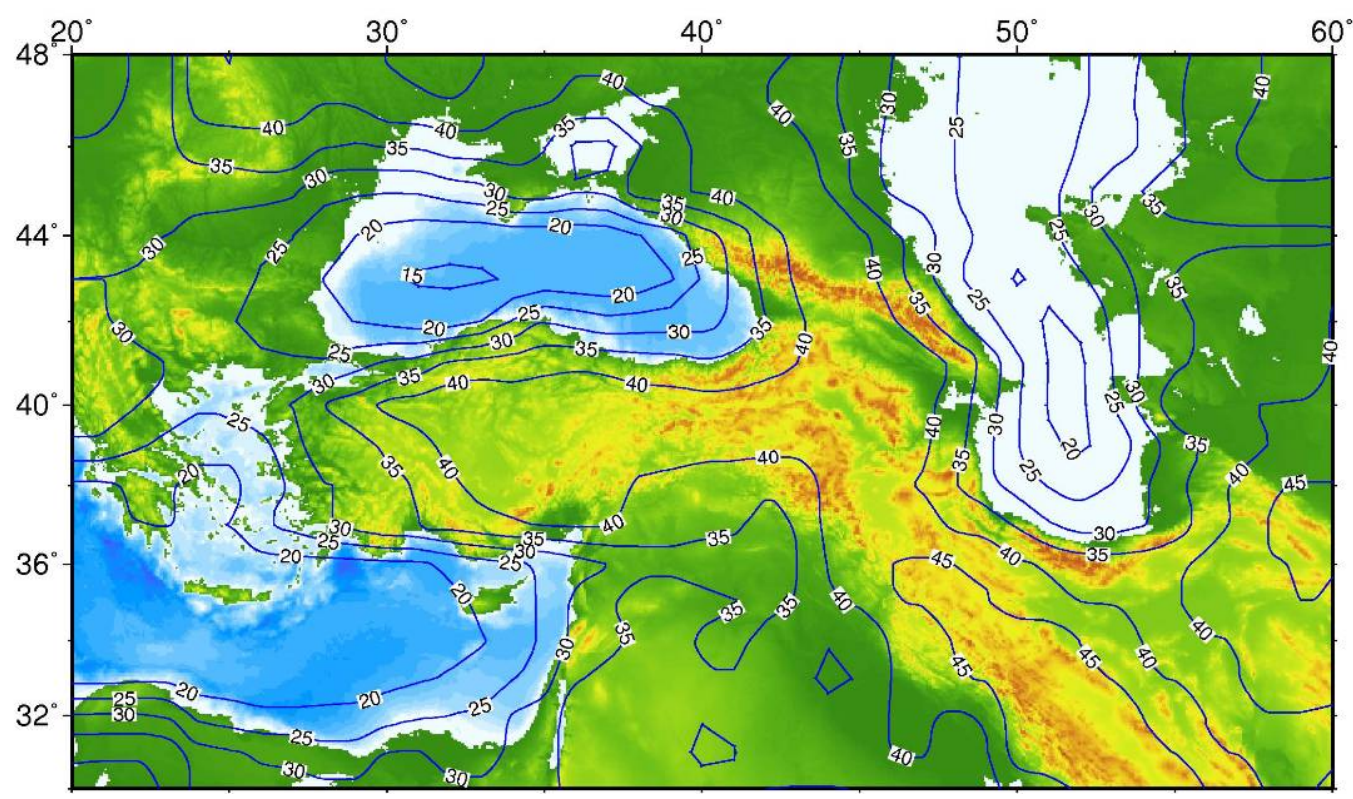

Figure 4-9: Depth distribution of the Moho discontinuities in the study area. The Moho depths are shown in contours. The depths of Moho are obtained by following Sun et al. (2004). 


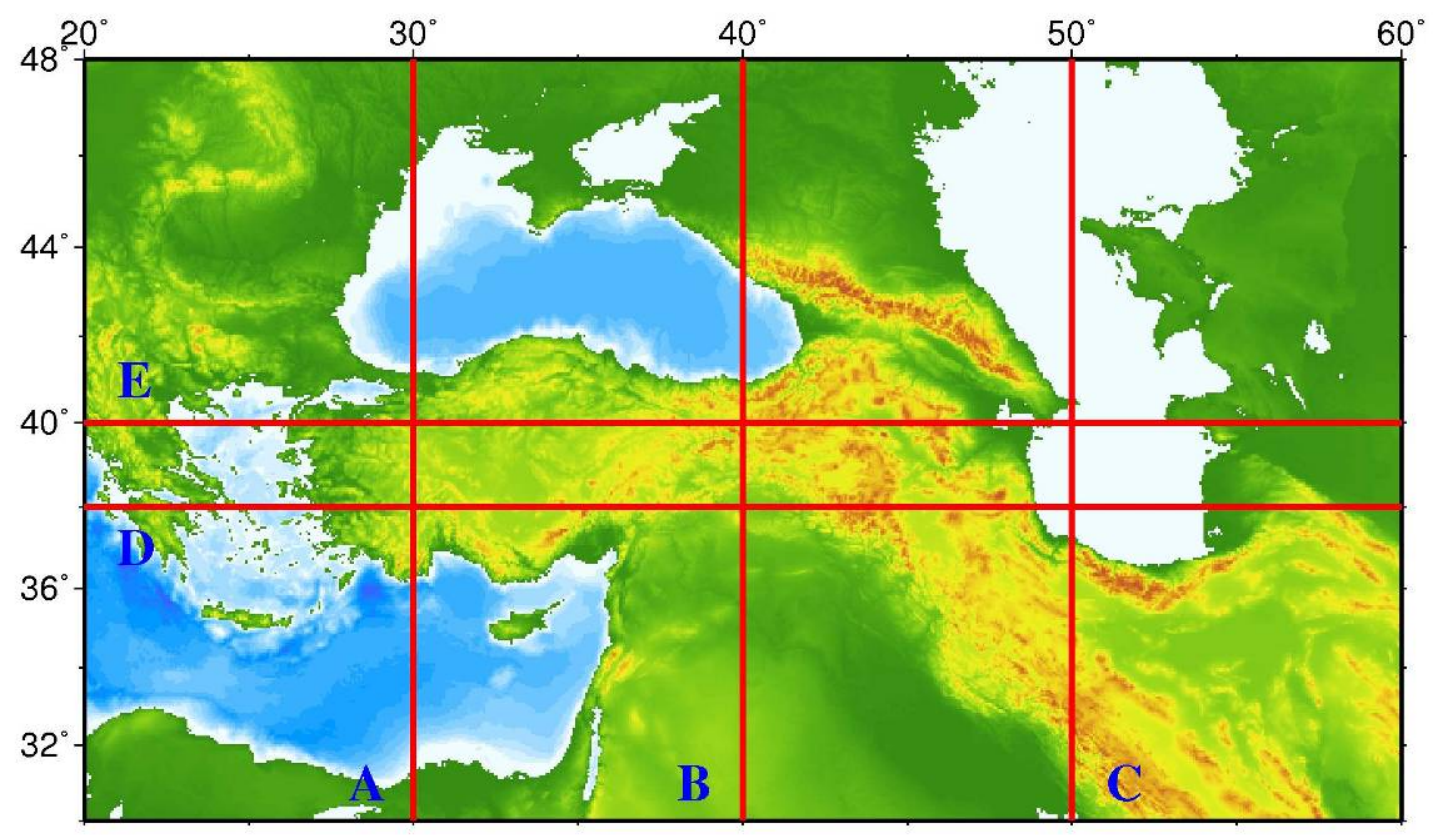

Figure 4-10: Locations of the vertical cross sections shown in Figures 411 and 4-12. 

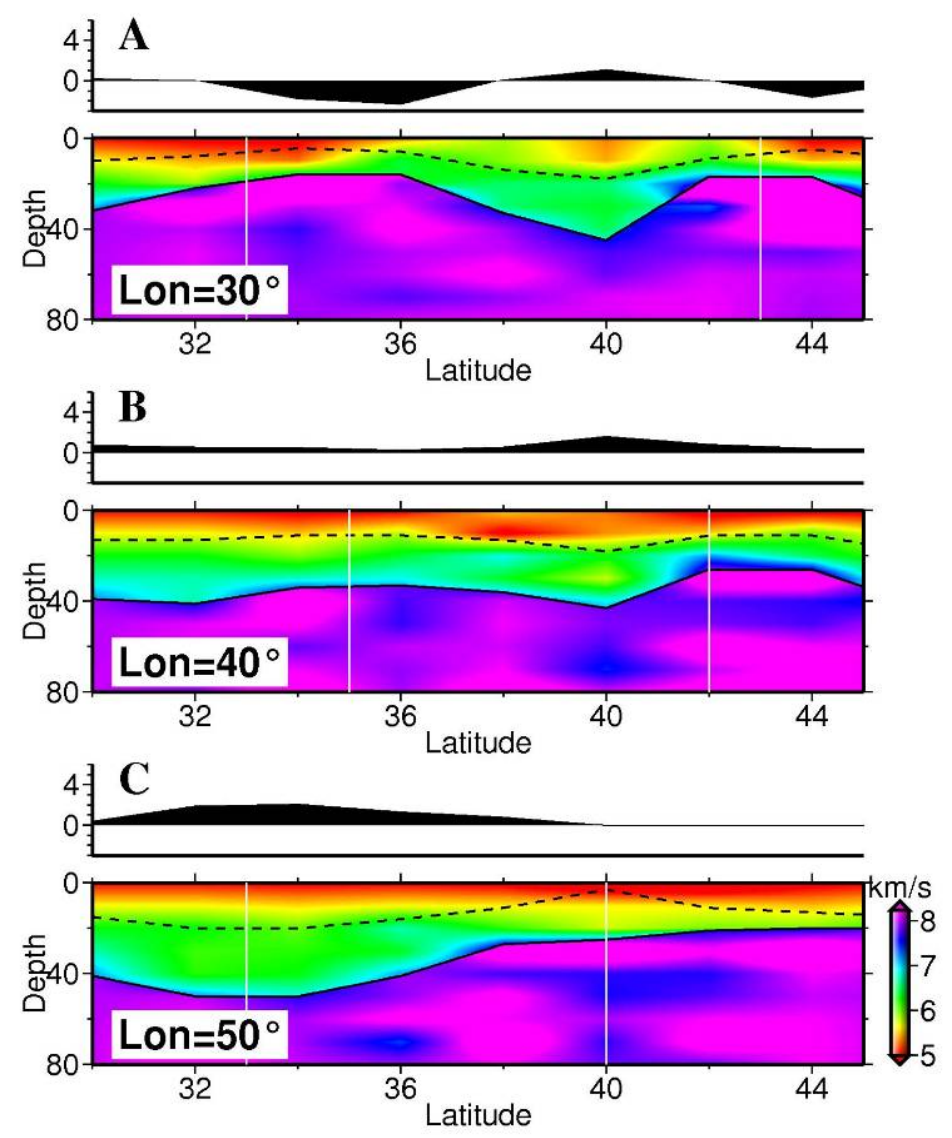

Figure 4-11: Vertical cross sections (shown in Figure 4-10) of $\mathrm{P}$-wave velocity. Cross sections $\mathrm{A}, \mathrm{B}$, and $\mathrm{C}$ at the longitudes of $30^{\circ}, 40^{\circ}$ and $50^{\circ}$ are plotted. The surface topography along each profile is shown on the top of each cross section. The black curved lines show the Conrad (dashed) and Moho (solid) discontinuities. Each grid in the region between the two white lines has a raypath hit count of 300 or above. The tomographic method is given in details by Sun and Toksöz (2006). 

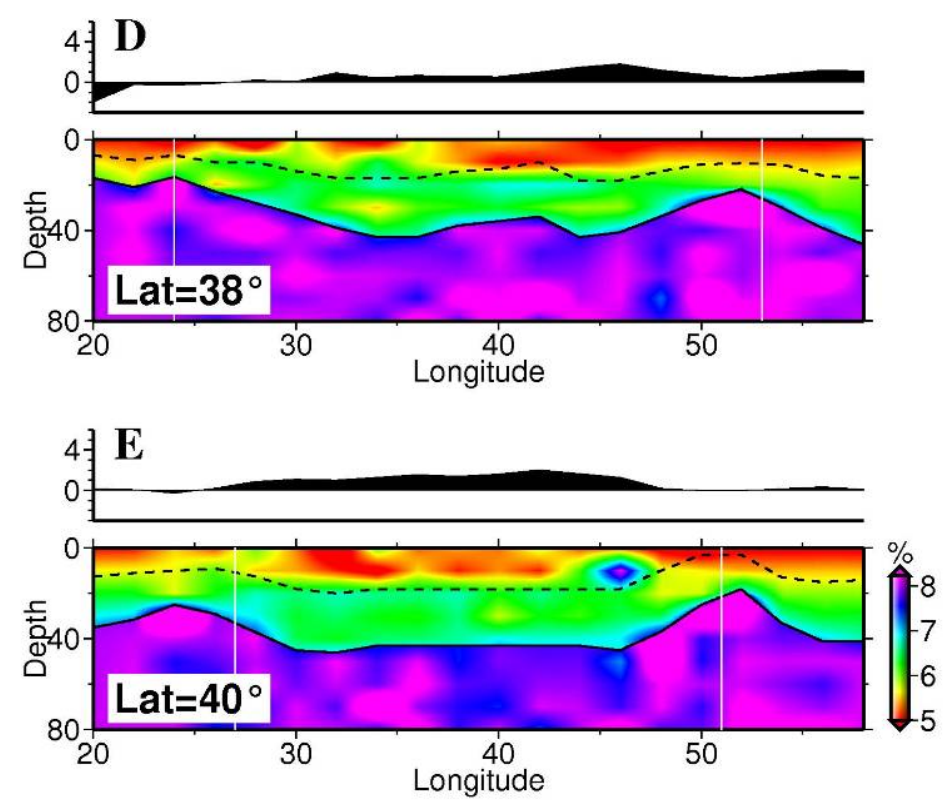

Figure 4-12: Vertical cross sections (shown in Figure 4-10) of P-wave velocity. Cross sections $\mathrm{D}$ and $\mathrm{E}$ at the Latitudes of $38^{\circ}$ and $40^{\circ}$ are plotted. The surface topography along each profile is shown on the top of each cross section. The black curved lines show the Conrad (dashed) and Moho (solid) discontinuities. Each grid in the region between the two white lines has a raypath hit count of 300 or above. The tomographic method is given in details by Sun and Toksöz (2006). 


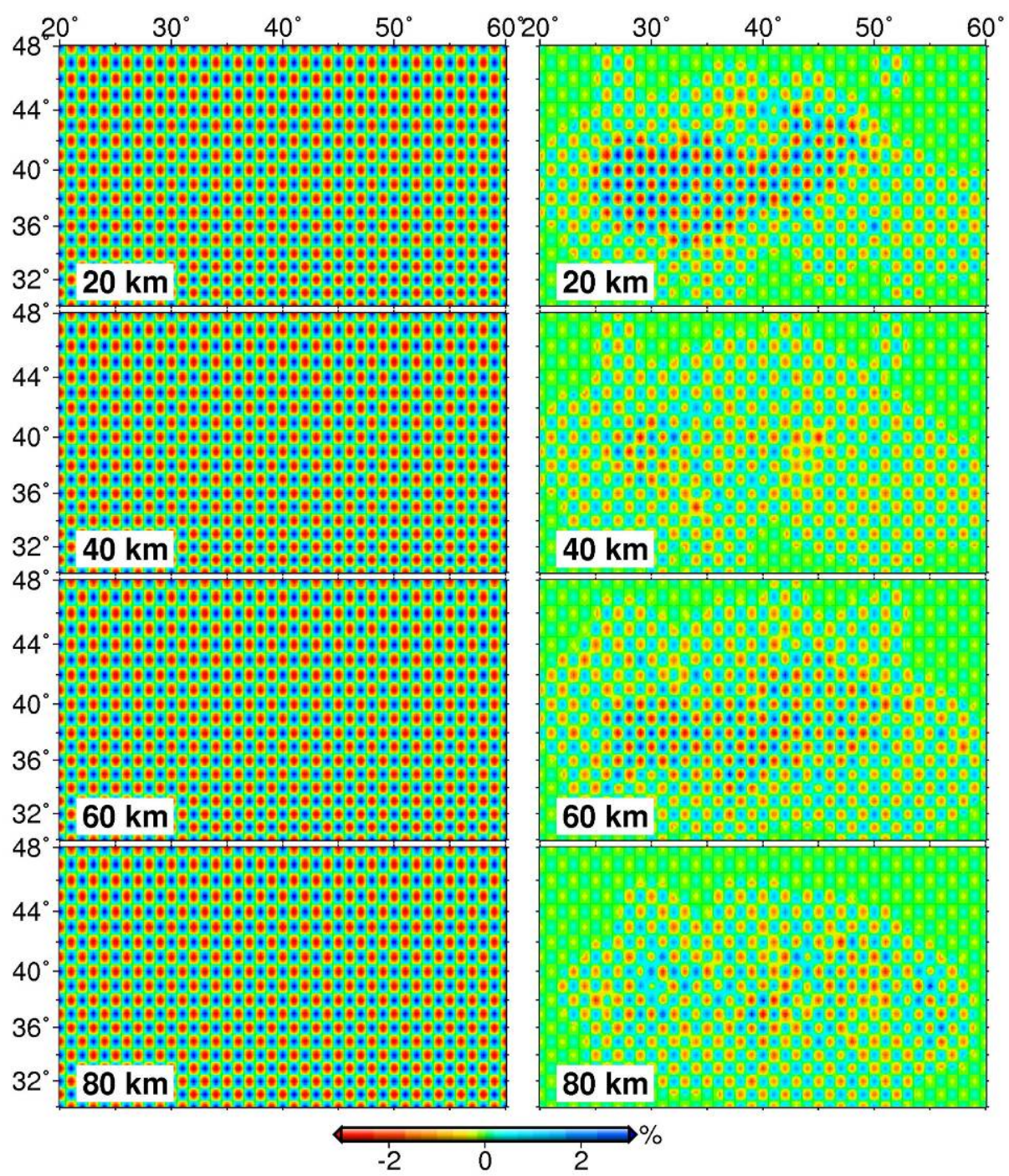

Figure 4-13: The input checkerboard (left) and results (right) at different depths when the grid shown in Figure 4-8 is adopted. The depth of the layer is shown at the lower-left corner of each map. Blue and red squares denote high and low velocities, respectively. The velocity perturbation scale is shown at the bottom. 


\section{References}

Abiche H, 1899, Gèologie de l'Armenie Occidentale; Description Orographique et gèologique, Translated into Russian by B Kolenko, Pyatigorsk

Adamia, Sh. A., Lordkipanidze, M. B., Zakariadze, G. S., 1977. Evolution of an active continental margin as exemplified by the Alpine history of the Caucasus. Tectonophysics, 40, 183-199.

Adamia, Sh. A., V.S. Alphaidze, E.G. Bombolakis, A.O. Chabukiani, S.I. Kuloshvili,, G.M. Majsuradze, and R.J. Martin, 2002a. Late Neogene-Quaternary chronology, volcanic and geodynamic activities of the Caucasus, Proceedings, XVII Congress of Carpathian-Balkan Geological Association, vol. 53 (Special Issue), Bratislava (edited by J. Michalik, L. Inran, and J. Vozar), 6 pp.

Adamia, Sh. A., V.M. Alania, G.D. Ananiashvili, E.G. Bombolakis, G.K. Chichua, D. Girsiashvili, R.J. Martin, and L. Tatarashvili, 2002b, Late Mesozoic Cenozoic geodynamic evolution of the eastern Georgian Oil-Gaz bearing basin (Transcaucasus), Proceedings, XVII Congress of Carpathian-Balkan Geological Association, vol. 53 (Special Issue), Bratislava.

Adamia, Sh. A., E.G. Bombolakis, A. Chabukiani, S. Kuloshivili, R.J. Martin, and L. Tatarashvili, 2002c. Deep structure and seismotectonics of the oil-and-gas bearing regions of Georgia. International Conference on Assessment of Seismic Risk in the Oil-Gas Bearing Areas, Geology Institute of Azerbaijan National Academy of Sciences and United Institute of Earth Physics of Russian Academy of Science, Abstract Oct. 28-30, 2002, Baku.

Adamia S, 2004. Active Structures in the Republic of Georgia: Report for Caucasian Seismic Information Network for Hazard and Risk Assessment, presented at CauSIN Hands-On Workshop, Strasbourg France, May 2004

Adamia S, Alania V, Ananiashvili G, Chabukiani A, Chichua D, Girsiashvili D, Tatarishvili L, 2004, General Assessment of the Lower and Middle Miocene Sandstones of the Kartli Basin (Eastern Georgia): unpublished

Adamia S, 2005, Field-Guide: Achara-Trialeti Fold-Thrust Mountain Belt: Borjomi Gorge, Report for Caucasian Seismic Information Network for Hazard and Risk Assessment, pp 1- 50

Alavi, M., 1994. Tectonics of the Zagros orogenic belt of Iran: new data and interpretations. Tectonophysics, vol. 229, pp. 211-238.

Al-Lazki, Ali I., E. Sandvol, D. Seber, M. Barazangi, N. Turkelli and R. Mohamad, 2004. Pn tomography imaging of mantle lid velocity and anisotrophy at the junction of the Arabian, Eurasian and African plates, Geophy. J. Int. 158, 1024-1040.

Allen M, Jackson J, Walker R, 2004, Late Cenozoic reorganization of the Arabia-Eurasia collision and the comparison of short-term and long-term deformation rates, Tectonics, TC2008, p. 1-16 
Aronov L.E., Gagelgatz A.A., Galperin E.I., 1961. Deep seismic sounding of the Earth Crust in the Central part of the Caspian Sea (in Russ.). Publishing House of Academy of Sciences, the USSR, Moscow.

Axen, G.J., P.S. Lam, M. Grove, and D.F. Stockli, 2001. Exhumation of the west-central Alborz Mountains, Caspian subsidence, and collision related tectonics, Geology, vol. 29, no. 6, pp. 559-562.

Ayvazishvili I V, Lebedeva T M, Makhatadze L N, Papalashvili V G, Pletnev K G, Siboshvili T I, Rustanovich D N, Shebalin N V, Fabritsiu, Z E, 1973, Zemletryaseniye 3 yanvarya 1970 goda v Borzhomskom rayone Translated Title: The earthquake of January 3, 1970, in the Borzhomi area: Tr. by Z. Javakashvili, Tiflis, USSR, Metsniyereba, p. 54.

Bailey A D, 1974, Near surface fault detection by magnetometer. California Geology, v. 27, p. 274.

Berberian, M., 1995. Master 'blind' thrust faults hidden under the Zagros folds: active basement tectonics and surface morphotectonics, Tectonophysics, vol. 241, pp. 193224.

Berberian, M., 1983. The southern Caspian: A compressional depression floored by a trapped, modified oceanic crust, Can. J. Earth Sci, vol. 20, pp. 163-183.

Berberian, M., M. Qorashi, J. A. Jackson, K. Priestley, and T. Wallace, 1992. The Rudbar-Tarom earthquake of 20 June 1990 in NW Persia: preliminary field and seismological observations, and its tectonic significance, Bull. Seism. Soc. Amer., vol. 82, pp. 1726-1755.

Blanc, E. J.-P., M.B. Allen, S. Inger, and H. Hassani, 2003. Structural styles in the Zagros Simple Folded Zone, Iran, J. Geol. Soc. London, vol. 160, pp. 401-412.

Bizova S, Copp M, Kurdin N, Rastsvetaev L, Trifonov V, 1973, Decoding of Tectonic Lineaments According to the Space Images of the Caucasus, Izvestia Visshikh Uchebnikh Zavadenii - Geology and Reconnaissance \#7

Caputo M, Gamkrelidze I, Malvezzi V, Sgrigna V, Shengelaia G, Zilpimiani D, 2000, Geostructural Basis and Geophysical Investigations for the Seismic Hazard Assessment and Prediction in the Caucasus, Il Nuovo Cimento, v. 23, n. 2, p. 191213.

Cisternas, A. and Philip, H., 1997. Seismotectonics of the Mediterranean region and the Caucasus, In: Historical and Prehistorical Earthquakes in the Caucasus, edited by D. Giardini and S. Balassanian, NATO ASI Ser. Environ., Kluwer Academic Publishers, 28, 39-77.

Copely, A. and Jackson, J., 2006. Active tectonics of the Turkish-Iranian Plateau, Tectonics, 25, No. 6, TC6006.

Davidson, J., J. Hassanzadeh, R. Berzins, D.F. Stockli, B. Bashukooh, B. Turrin, and A. Pandamouz, 2004. The geology of Damavand volcano, Alborz Mountains, northern Iran, GSA Bulletin, vol. 116, no 1/2, pp. 16-29. 
DeMets, C., Gordon, R. G., Argus, D. F., and Stein, S. (1990). Current plate motions. Geophys. J. Int., 101:425-478.

Dercourt J., Zonenshain L.P., Ricou L.E., Kazmin V.G., Le Pichon X., Knipper A.L., Grandjacquet C., Sbortshikov I.M., Geyssant J., Lepvrirer C., Pechersky D.H., Boulin J., Sibuet J.C., Savostin L.A., Sorokhtin O., Westphal M., Bazchenov M.L., Lauer J.P. and Biju, 1986. Geological evolution of the Tethys belt from the Atlantic to the Pamirs since the Lias. Tectonophysics, 123, 241-315.

Dewey, J.F., M.R. Hempton, W.S.F. Kidd, F. Saroglu and A.M.C. Sengör, 1986.

Shortening of continental lithosphere: the neotectonics of Eastern Anatolia - a young collision zone, in Collision Tectonics (edited by M.P. Coward and A.C. Ries), Geological Society Special Publication No. 19, pp. 3-36.

Dotuev, S.I., 1986. Nappe structure of the Greater Caucasus Range, Geotectonics, vol. 20, no. 5, pp. 420-430.

Fan, G., T. Wallace, and D. Zhao, 1998. Tomographic imaging of deep velocity structure beneath the eastern and southern Carpathians, Romania: Implications for continental collision. J. Geophys. Res. 103, 2705-2723.

Formuru, T. and B.L.N. Kennett, 1997. On the nature of regional seismic phases - II, On the influence of structural barriers", Geophys. J. Int., vol. 129, pp. 221-234.

Eberhart-Phillips, D., 1986. Three dimensional velocity structure in Northern California Coast Ranges from inversion of local earthquake arrival times. Bull. Seismol. Soc. Am. 76, 1025-1052.

Gagelgantz A.A., Galperin E.I., Kosminskaya I.P., and Krakshina P.M., 1958. Structure of the Earth's crust of the central part of the Caspian Sea on the basis of deep seismic sounding (in Russ.). Dokladi Acad. Nauk, the USSR, v. 123 \# 3, pp. 520523.

Gamkrelidze I, Giorgobiani T, Kuloshvili S, Lobzhanidze G, Shengelaia G, 1998, Active Deep Faults Map and Catalogue for the Territory of Georgia, Bulletin of the Georgian Academy of Sciences, v. 157, n. 1

Godoladze T, 2004. Seismicity and Seismic Hazard Assessment of Georgia, Report for Caucasian Seismic Information Network for Hazard and Risk Assessment, pp 1-17.

Hearn, T. M., 1996. Anisotropic Pn tomography in the western United States, J. Geophys. Res. 101, 8403-8414.

Hearn, T.M. and J. F. Ni, 1994. Pn velocities beneath continental collision zones: the Turkish-Iranian plateau, Geophys. J. Int., 117, 273-283.

Hempton, M.R., 1987. Constraints on Arabian plate motion and extensional history of the Red Sea, Tectonics, vol. 6, no. 6, pp. 687-705.

Hempton, M.R., 1985. Structure and deformation history of the Bitlis suture near Lake Hazar, southeastern Turkey, GSA Bulletin, vol. 96, pp.233-243. 
Jackson, James and Dan McKenzie, 1988. The relationship between plate motions and seismic moment tensors, and the rates of active deformation in the Mediterranean and Middle East, Geophys. Journal, vol. 93, pp. 45-73.

Jackson, J. 1992. Partitioning of strike-slip and convergent motion between Eurasia and Arabia in eastern Turkey and the Caucasus, J. Geophys. Res., 97, 12,471-12,479.

Jackson, J. and McKenzie, D. P., 1984. Active tectonics of the Alpine-Himalayan belt between western Turkey and Pakistan, Geophys. J. R. Astron. Soc., 77, 185-264.

Jackson, James, 2001. Living with earthquakes: know your faults, J. Earthquake Engineering, vol. 5, Special Issue 1, pp. 5-123.

Jackson, J., Priestley, K., M. Allen, and M. Berberian, 2002. Active tectonics of the South Caspian Basin, Geophys. J. Int. 148, 214-245.

Kadinsky-Cade, K., M. Barazangi, J. Oliver and B. Isacks, 1981. Lateral variations of high-frequency seismic wave propagations at regional distances across the Turkish and Iranian plateaus, J. Geophys. Res. 86, 9377-9396.

Khain, V. E., 1984. The Alpine-Mediterranean fold belt of the U.S.S.R., Episodes, 7, 2029.

Kissling, E., W. L. Ellsworth, D. Eberhart-Phillips, and U. Kradolfer, 1994. Initial reference models in local earthquake tomography. J. Geophys Res. 99, 1963519646.

Koçyiğit, A., Yılmaz, A., Adamia, Sh. A., Kuloshvili, S., 2001, Neotectonics of east Anatolian Plateau (Turkey) and Lesser Caucasus: implications for transition from thrusting to strike-slip faulting, Geodinamica Acta, 14, 177-195.

Koronovskii N V, Sim L A, Boinagryan, B V, 1996, Neotectonic and recent fields of tectonic stresses in the Caucasus and seismicity: Moscow University Geology Bulletin, v. 51, p. 1-10.

Leveque, J., L. Rivera, and G. Wittlinger, 1993. On the use of the checkerboard test to assess the resolution of tomographic inversions. Geophys. J. Int. 115, 31318.

Mangino, S and K. Priestley, 1998. The crustal structure of the southern Caspian region, Geophys. J. Int. $133,630-648$.

McCluskey, S., S. Balassanian, A. Barka, C. Demir, S. Ergintav, I. Georgiev, O. Gurkan, M. Hamburger, K. Hurst, H. Kahle, K. Kastens, G. Kekelidze, R. King, V. Kotzev, O. Lenk, S. Mahmoud, A. Mishin, M. Nadariya, A. Ouzounis, D. Paradissis, Y. Peter, M. Prilepin, R. Reilinger, I. Sanli, H. Seeger, A. Tealeb, M. N. Toksöz, and G. Veis, 2000. Global Positioning System constraints on plate kinematics and dynamics in the eastern Mediterranean and Caucasus, J. Geophys. Res., vol. 105, no. B3, pp. 5695-5719.

McQuarrie, N., 2004. Crustal scale geometry of the Zagros fold-thrust belt, Ira", J. Struct. Geol., vol. 26, pp. 519-535.

McKenzie, D., 1972. Active tectonics of the Mediterranean region, Geophys. J. R. astr. Soc. 30, 109-185. 
Milanovsky E.E., 1968. Neotectonics of the Caucasus (in Russ.). "Nedra”, Moscow, pp. $1-483$.

Milanovsky E.E., 1977. Neotectonics. In: Dumitrashko N., Antonov B, Shirinov N. (eds.). The general description and history of evolution of the relief of the Caucasus (in Russ.). "Nauka", Moscow, pp. 31-45.

Molnar P. and Tapponnier P., 1975, Cenozoic Tectonics of Asia; Effects of a Continental Collision, Science, v. 189, p. 419-426.

Neprochnov, Y. P., I. P. Kosminskaya, and Y.P. Malovitsky, 1970. Structure of the crust and upper mantle of the Black and Caspian seas, Tectonophysics 10, 517-538.

Orgulu, G., Aktar, M., Turkelli, N., Sandvol, E., and Barazangi, M., 2003. Contribution to the seismotectonics of the eastern Anatolian Plateau from moderate and small size events, Geophys. Res. Lett., 30(24).

Paige, C., and M. Saunders, 1982. LSQR: An algorithm for sparse linear equations and sparse least squares. ACM Trans. Math. Software 8, 471.

Phillip, H., A. Cisternas, A. Gvishiani, and A. Gorshkov, 1989. The Caucasus: an actual example of the initial stages of continental collision, Tectonophysics, vol. 161, pp. $1-21$.

Rebai S, Philip H, Dorbath L, Borissoff B, Haessler, H, Cisternas A, 1993, Active tectonics in the Lesser Caucasus; coexistence of compressive and extensional structures: Tectonics, v. 12, p. 1089-1114.

Reilinger, R E., McClusky, S. C., Souter, B. J., Hamburger, M. W., Prilepin. M. T., Mishin, A., and Guseva, T., 1997, Preliminary estimates of plate convergence in the Caucasus collision zone from Global Positioning System measurements, Geophys. Res. Lett., 24, 1815-1818.

Reilinger, R. E., McClusky, S. C., Vernant, P., and 22 others, 2006, GPS constraints on continental deformation in the Africa-Arabia-Eurasia continental collision zone and implications for the dynamics of plate interactions, J. Geophys. Res., 111, B05411, doi:10.1029/2005JB004051.

Ritzwoller, M. H., M. P. Barmin, A. Villasenor, A. L. Levshin, and E. R. Engdahl, 2002. Pn and Sn tomography across Eurasia to improve regional seismic event locations. Tectonophysics 358, no. 1-4, 39-55.

Ritzwoller, M.H. \& Levshin, A.L., 1998. Eurasian surface wave tomography: group velocities, Journal of Geophysical Research, 103, 4839-4878.

Rodgers, A. J., J. F. Ni, T. M. Hearn, 1997. Propagation characteristics of short-period Sn and Lg in the Middle East, Bull. Seismo. Soc. Amer. 87, 396-413.

Ruppel, C. and McNutt M., 1990, Regional compensation of the Greater Caucasus mountains based on an analysis of Bouger gravity data, Earth and Planet. Sci. Lett., $98,360-379$. 
Sandvol, E., N. Turkelli, and M. Barazangi, 2003. The Eastern Turkey Seismic Experiment: the study of a young continent-continent collision, Geophys. Res. Letters, vol. 30, no. 24, pp. 1-1 and 1-2.

Note: Also the eight papers, on this topic, that follow this paper in vol. 30.

Sengör, A., M., and W. S. Kidd, 1979. Post-collisional tectonics of the Turkish-Iranian Plateau and a comparison with Tibet. Tectonophysics 55, 361-376.

Sobornov, K.O., 1996. Structural segments of the East Caucasus Thrust Belt. Geotectonics, vol. 30, no. 5, pp. 410-421.

Sun, Y., X. Li, S. Kuleli, F. D. Morgan, and M. N. Toksöz, 2004. Adaptive moving window method for 3-D P-velocity tomography and its application in China. Bull. Seism. Soc. Am. 94, 740-746.

Sun, Y., and M. N. Toksöz, 2006. Crustal structure of China and surrounding regions from P wave traveltime tomography. J. Geophys. Res., 111, B03310, doi:10.1029/2005JB003962.

Triep, E. G., Abers, G. A., Lerner-Lam, A. L., Mishatkin, V., Zakharchenko, N., and Starovolt, O., 1995. Active thrust front of the Greater Caucasus: The April 29, 1991, Racha earthquake sequence and its tectonic implications, J. Geophys. Res., 100, 4011-4033.

Tutberidze, 2004. Geology and Petrology of Alpine Late Orogenic Magmatism of the Central Part of the Caucasus, (V. Gugushvili, ed), tr. by S. Adamia, Tbilisi University Publishers, Tbilisi, 1-340.

Um, J., and C. Thurber, 1987. A fast algorithm for two-point seismic ray tracing. Bull. Seism. Soc. Am. 77, 972-986.

Westaway, R., 1990, The Tripoli, Libya earthquake of September 4, 1974: Implications for the active tectonics of the central Mediterranean. Tectonics, v. 9, 1974.

Yu, X., Y. Chen, and P. Wang, 2003. Three-dimensional P wave velocity structure in Beijing-Tianjin-Tangshan area. Acta Seismol. Sin. 25, 1-14.

Zhao, D., 2001. New advances of seismic tomography and its applications to subduction zones and earthquake fault zones: A review. The Island Arc 10, 68-84.

Zhao, D., A. Hasegawa, and S. Horiuchi, 1992. Tomographic imaging of P and S wave velocity structure beneath northeastern Japan. J. Geophys. Res. 97, 19909-19928.

Zhao, D., A. Hasegawa, and H. Kanamori, 1994. Deep structure of Japan subduction zone as derived from local, regional and teleseismic events. J. Geophys. Res. 99, 223122329.

Zhao, D., Y. Xu, D. Wiens, L. Dorman, J. Hilderbrand, and S. Webb, 1997. Depth extent of the Lau back-arc spreading center and its relation to subduction processes. Science 278, 254-257. 


\section{Appendix A: Summary of the Project Database}

\section{A.1 Introduction}

This data collected over the course of this project are listed below. The data files are too large to include in this document; they are attached on a cd-rom. Submitted information includes: 1) descriptions of seismic networks in Armenia, Azerbaijan, and Georgia; 2) event catalogs of the region; 3) phase arrival data from local historical and digital networks; and 4) a geological map of Georgia.

Initially, the CauSIN project was devoted to collecting historical (pre-digital) data. Over the past three years, digital data has become available from Azerbaijan and Georgia. It is important to note that these new digital data have been relied on heavily in the development of crustal models and in the crustal tomography shown in Chapter 3. Much of these data have not previously been reported or used to develop crustal models.

For completeness and ease of reference, we list all the events that have been used in the project, whether analog or digitally recorded. These data have been carefully examined at NER, MIT, and LLNL, and much of these data have been submitted by LLNL to AFTAC, with the exception of the phase pick data from Azerbaijan.

We are particularly indebted in Cemil Gurbuz and colleagues from Kandilli Observatory in Istanbul for their assistance throughout the project, and for allowing us to freely integrate their data into our models. The data from eastern Turkey are not reported in this appendix.

Additionally, phase pick data from the ISC and SMDC databases were used in our crustal tomography study, but are not reported here. 


\section{A.2 Events Catalogs}

Two catalogues are provided on the cd-rom as Microsoft Access tables; their formats are shown in Figure A-1.

The first, CATALV3_cat.mdb, is a complete catalog of historical events in the region. It contains 57,481 events with magnitudes ranging from $M=8.0$ to less than $M=1.0$. The dates of the events range from $139 \mathrm{AD}$ to 2001 , and the record format includes the following fields:

- Date and Time

- Time

- Location Coordinates

- Magnitude

- Depth

The GSHAP.mdb database is a historical catalog of large events in the region and is widely used by scientists in the Caucasus and surrounding regions. It contains 4,126 events from $2000 \mathrm{BC}$ to $1993 \mathrm{AD}$, with estimated magnitudes ranging from 3.5 to 8.1. The record format includes the following fields:

- Flinn-Engdahl Region number

- Country-ocean code

- Date and Time

- Location Coordinates

- Epicenter source reference number and description

- Hypocentral depth and descriptor

- Magnitude (with calculation category and data source)

- Maximum epicentral intensity and intensity scale

- Event type and associated phenomena description 


\section{A.3 Regional Networks}

During the Soviet era, there was an extensive analog network throughout the Caucasus and central Asia. When the Soviet Union collapsed, the networks in large part were abandoned, and in the early and mid 1990s few critical stations remained. In the later part of the decade, a reinvigoration of the seismic networks occurred. By 2000, with increased stabilization in the region, digital networks were introduced.

Currently, the most extensive networks are in Azerbaijan and Georgia. The Azeri network (Figure A-2, Table A-1) contains 14 telemetered Kinemetric stations which were installed after the strong $M=6.2$ Caspian Sea earthquake of Nov 25, 2000. The Georgian network (Figure A-3, Table A-2) has 15 digital stations; some are these are co-located with historical analog stations. Armenia is in the process of upgrading its analog stations (Figure A-4, Table A-3) to digital. With the exception of the IRIS station at Garni, there are currently no continuously operating digital stations in Armenia.

\section{A.4 Phase arrival data}

Two time pick databases are submitted with this report. The first, Georgian_phase_picks.inp, (in hypo71 input file format) is a compilation of arrivals from events ranging from 1955 to 2003 from both analog and digital stations. This dataset includes approximately 8,600 $\mathrm{P}$ and $\mathrm{S}$ phase time picks (Figure A-5) for 81 stations and 479 events of magnitude 3.5 and greater. Most of the travel times were picked from analog records from local stations in the Caucasus region. 
The second database, Azeri_phase_picks.asc, is from the digital network in Azerbaijan. This includes 6,527 $\mathrm{P}$ arrivals and 4,334 S arrivals for events in the years 2003 to 2006. Event magnitudes range from $M=0.51$ to $M=7.09$.

These time pick databases were combined with data from the Turkish regional networks, ISC, and SMDC to improve ray coverage as much as possible for the crustal studies done in Chapter 3.

\section{A.5 Geology of Georgia}

One milestone achieved during this project was the first digital geologic map for the Republic of Georgia, which is included on the CDROM accompanying this report in the file Geology_GEORGIA.pdf. 

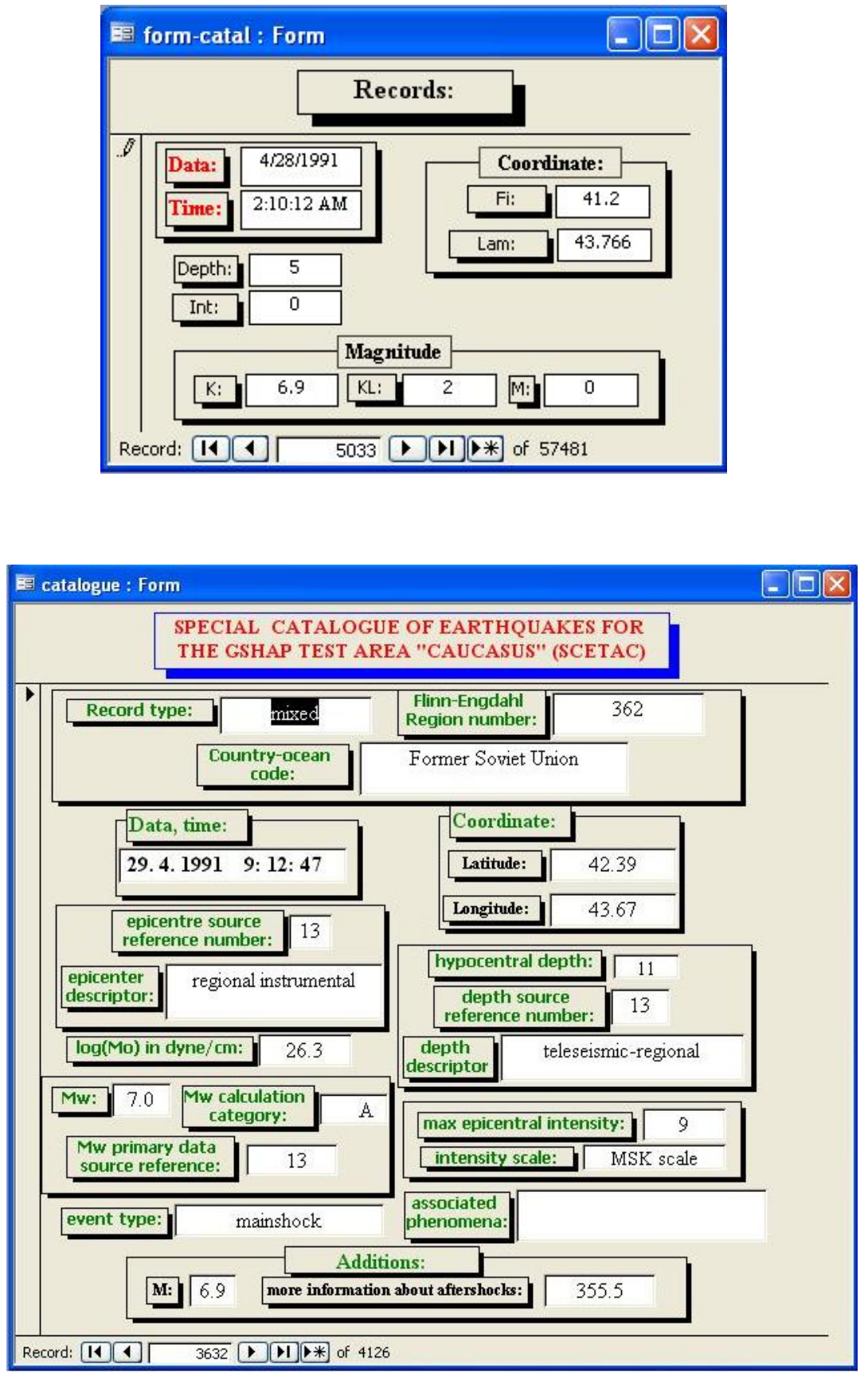

Figure A-1: Examples of the forms for the historical events catalogues discussed in Section A-3. These field records show data from the 1991 Racha earthquake in Georgia (top record: CATALV3_cat and bottom record: GSHAP database) 


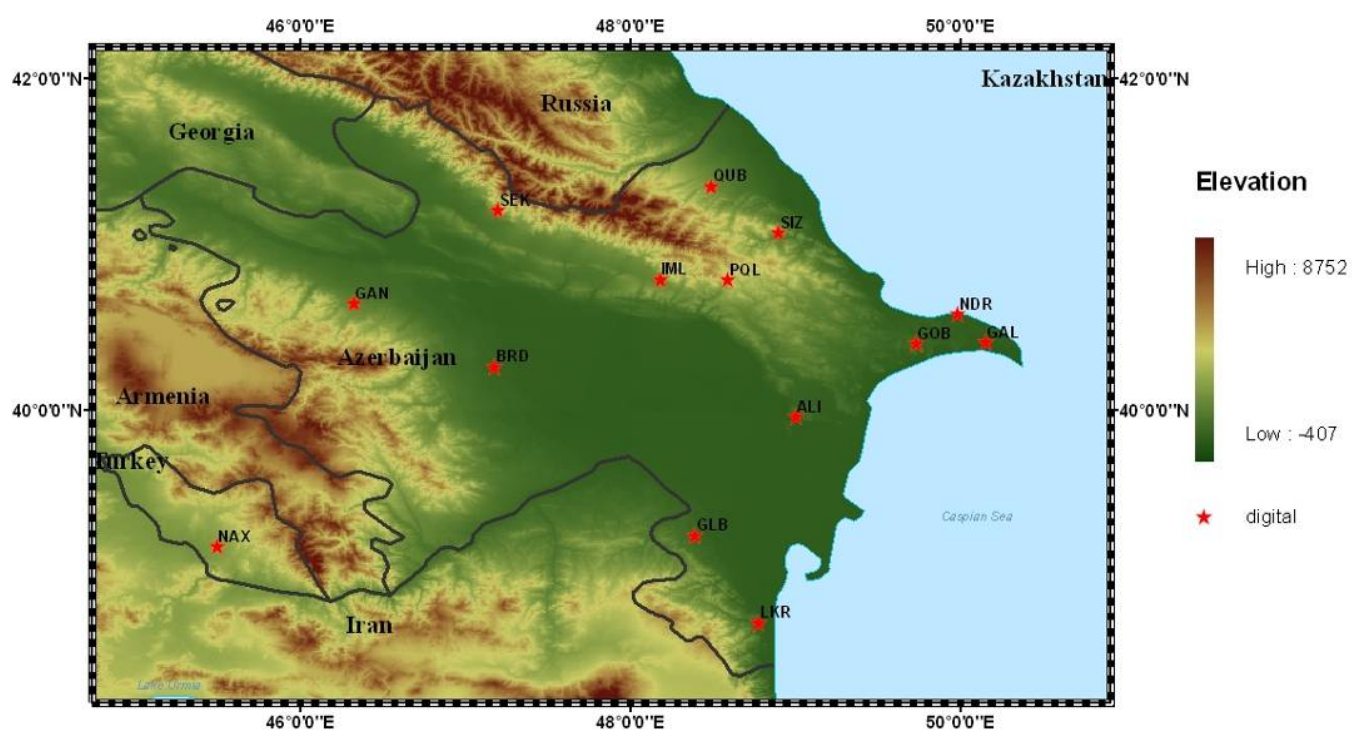

Figure A-2: The network in Azerbaijan. The 14 telemetered kinemetric stations were allocated based on seismicity distribution of the Azerbaijan region.

\begin{tabular}{||l|c|c|c|r|c||}
\hline \multicolumn{7}{|c||}{ Azerbaijan Digital Seismic Network } \\
\hline \hline \multicolumn{1}{||c|}{ Station } & ID & \multicolumn{1}{c||}{ Lat. } & \multicolumn{1}{c|}{ Long. } & Elev. (m) & Network Info \\
\hline Ali-Bairamli & ALI & 39.958 & 49.006 & 58.00 & digital \\
\hline Barda & BRD & 40.263 & 47.179 & 82.00 & digital \\
\hline Gala & GAL & 40.410 & 50.155 & 14.00 & digital \\
\hline Ganja & GAN & 40.646 & 46.322 & 560.00 & digital \\
\hline Galilabad & GLB & 39.242 & 48.393 & 152.00 & digital \\
\hline Gobu & GOB & 40.401 & 49.733 & 224.00 & digital \\
\hline Ismailli & IML & 40.792 & 48.182 & 698.00 & digital \\
\hline Lenkaran & LKR & 38.710 & 48.779 & 52.00 & digital \\
\hline Nakhchivan & NAX & 39.174 & 45.495 & 934.00 & digital \\
\hline Nardaran & NDR & 40.581 & 49.987 & 20.00 & digital \\
\hline Pirkuli & PQL & 40.789 & 48.593 & 1475.00 & digital \\
\hline Quba & QUB & 41.355 & 48.493 & 642.00 & digital \\
\hline Seki & SEK & 41.209 & 47.198 & 824.00 & digital \\
\hline Siazan & SIZ & 41.076 & 48.899 & 959.00 & digital \\
\hline \hline
\end{tabular}

Table A-1: Azerbaijan digital station locations were provided by Republican Center of Seismological Survey of Azerbaijan. 


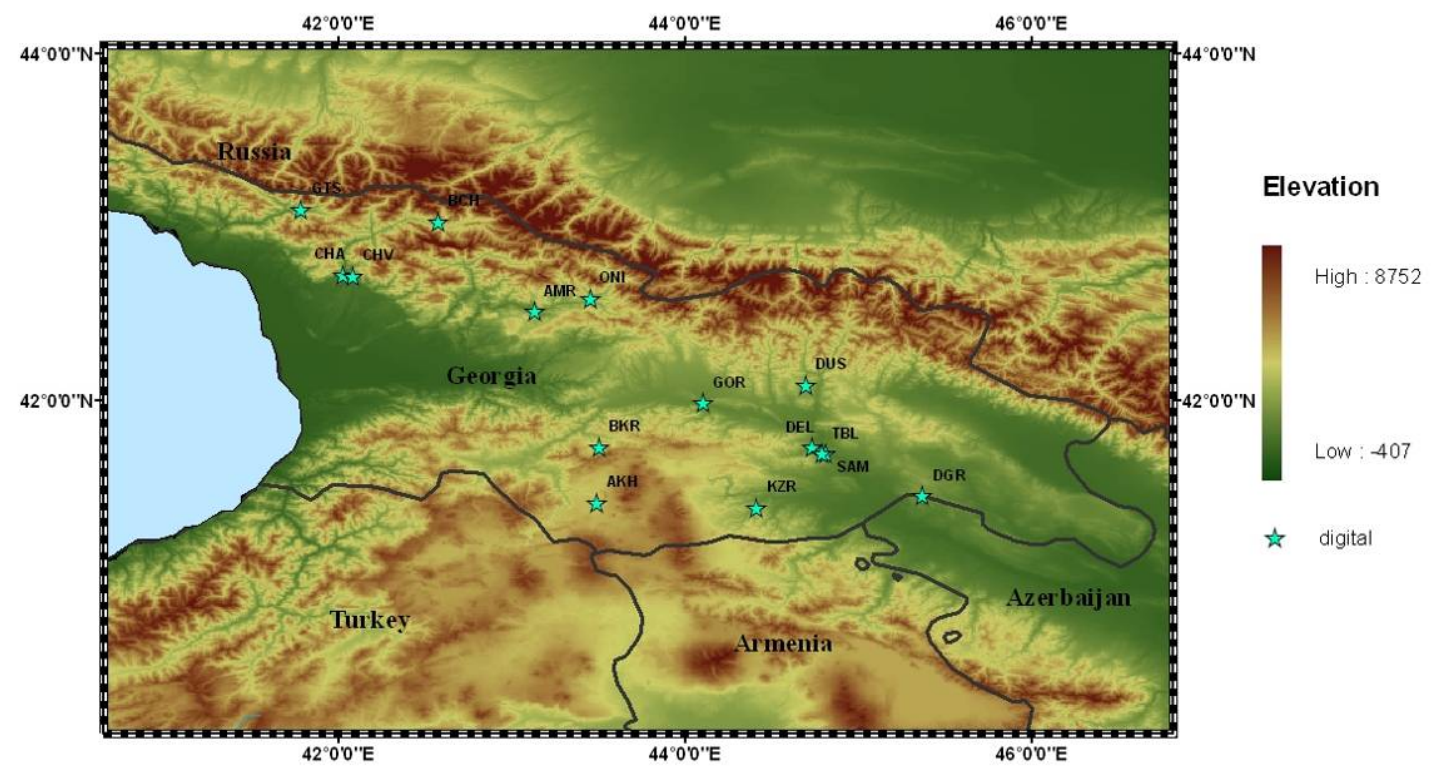

Figure A-3: The Georgian digital stations. Georgia has a large number of analog stations, many of which will be converted to digital, but only the currently operating digital network are shown here.

\begin{tabular}{||l|l|r|r|r|c||}
\hline \hline \multicolumn{7}{|c||}{ Georgian Digital Seismic Network } \\
\hline \hline \multicolumn{1}{|c|}{ Station } & ID & \multicolumn{1}{c|}{ Lat. } & \multicolumn{1}{c|}{ Long. } & Elev. (m) & Network Info \\
\hline Akhalkalaki & AKH & 41.4100 & 43.4927 & 1708.0 & digital \\
\hline Ambrolauri & AMR & 42.5155 & 43.1368 & 614.0 & digital \\
\hline Becho & BCH & 43.0332 & 42.5783 & 1700.0 & digital \\
\hline Bakuriani & BKR & 41.7337 & 43.5032 & 1798.0 & digital \\
\hline Chala & CHA & 42.7278 & 42.0263 & 315.0 & digital \\
\hline Ch'k'valeri & CHV & 42.7183 & 42.0840 & 390.0 & digital \\
\hline Delisi & DEL & 41.7308 & 44.7382 & 510.0 & digital \\
\hline David-gareji & DGR & 41.4507 & 45.3730 & 690.0 & digital \\
\hline Dushet'i & DUS & 42.0902 & 44.7018 & 946.0 & digital \\
\hline Gori & GOR & 41.9855 & 44.1087 & 648.0 & digital \\
\hline Adgara & GTS & 43.1064 & 41.7838 & 605.0 & digital \\
\hline Kazret'i & KZR & 41.3815 & 44.4152 & 740.0 & digital \\
\hline Oni & ONI & 42.5903 & 43.4522 & 810.0 & digital \\
\hline Sameba & SAM & 41.6972 & 44.8157 & 465.0 & digital \\
\hline Tbilisi & TBL & 41.6938 & 44.7925 & 420.0 & digital \\
\hline \hline
\end{tabular}

Table A-2: Network of 15 digital station locations is provided by the Institute of Geophysics in Georgia. 


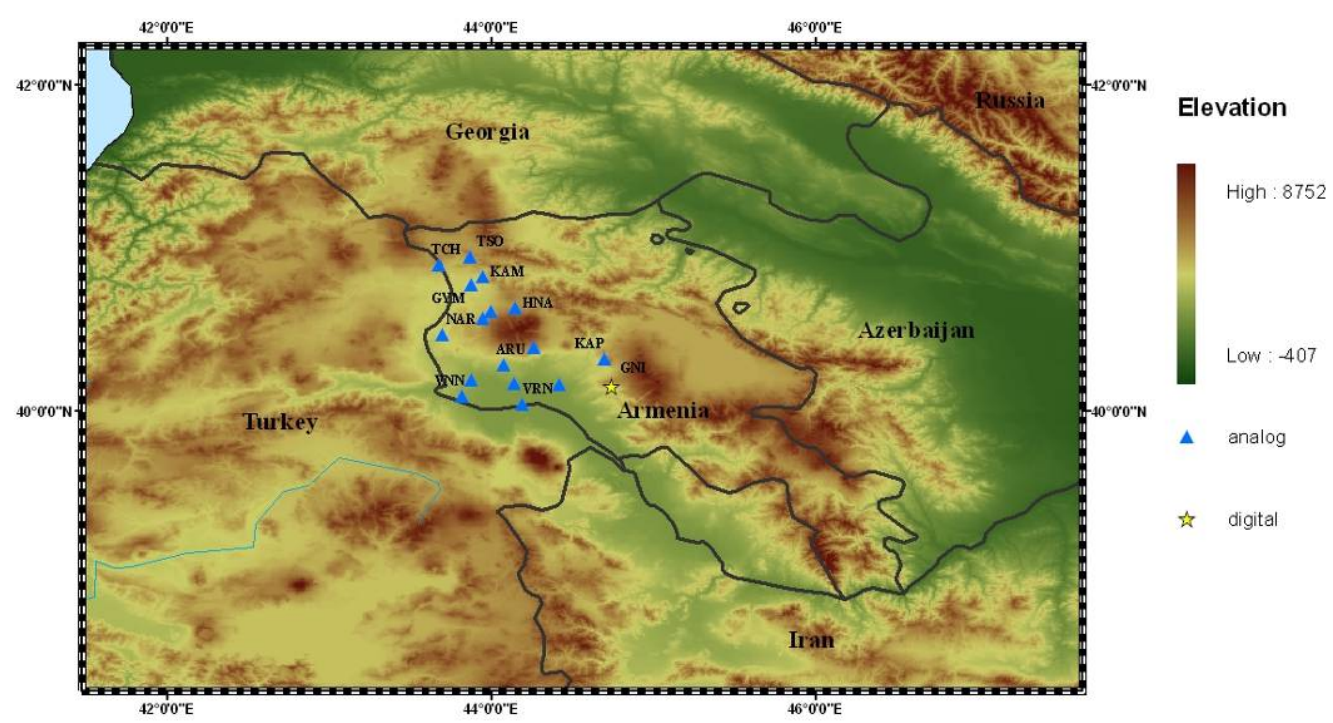

Figure A-4: Map of the Armenian stations (scale of 1: 3,000,000), including the digital IRIS station in Garni.

\begin{tabular}{||l|l|l|l|r|c||}
\hline \multicolumn{7}{|c||}{ Armenian Seismic Network } \\
\hline \multicolumn{1}{|c|}{ Station } & \multicolumn{1}{|c||}{ ID } & \multicolumn{1}{c||}{ Lat. } & \multicolumn{1}{c||}{ Long. } & \multicolumn{1}{c||}{ Elev. (m) } & Network Info \\
\hline Amberd & AMB & 40.388 & 44.259 & 2200.0 & analog \\
\hline Araks & AKS & 40.191 & 43.885 & 1160.0 & analog \\
\hline Aruch & ARU & 40.283 & 44.091 & 1200.0 & analog \\
\hline Gyumri & GYM & 40.810 & 43.831 & 1560.0 & analog \\
\hline Harich & HAR & 40.608 & 44.000 & 1980.0 & analog \\
\hline Hnaberd & HNA & 40.633 & 44.144 & 2150.0 & analog \\
\hline Kamo & KAM & 40.825 & 43.950 & 1230.0 & analog \\
\hline Kaputan & KAP & 40.322 & 44.699 & 1700.0 & analog \\
\hline Lernakert & LER & 40.567 & 43.950 & 1990.0 & analog \\
\hline ANNP & NPP & 40.172 & 44.138 & 945.0 & analog \\
\hline Nor Artik & NAR & 40.465 & 43.716 & 1550.0 & analog \\
\hline Parakar & PAR & 40.161 & 44.424 & 890.0 & analog \\
\hline Tchakhmakh & TCH & 40.900 & 43.700 & 1860.0 & analog \\
\hline Tsoghamarg & TSO & 40.950 & 43.867 & 1970.0 & analog \\
\hline Vanand & VNN & 40.103 & 43.823 & 1020.0 & analog \\
\hline Vardanashen & VRN & 40.049 & 44.191 & 841.0 & analog \\
\hline Garni & GNI & 40.1495 & 44.7414 & 1609.00 & digital \\
\hline \hline
\end{tabular}

Table A-3. All Armenian seismic stations were provided by the National Survey for Seismic Protection, except the location of Garni which is an IRIS station. 

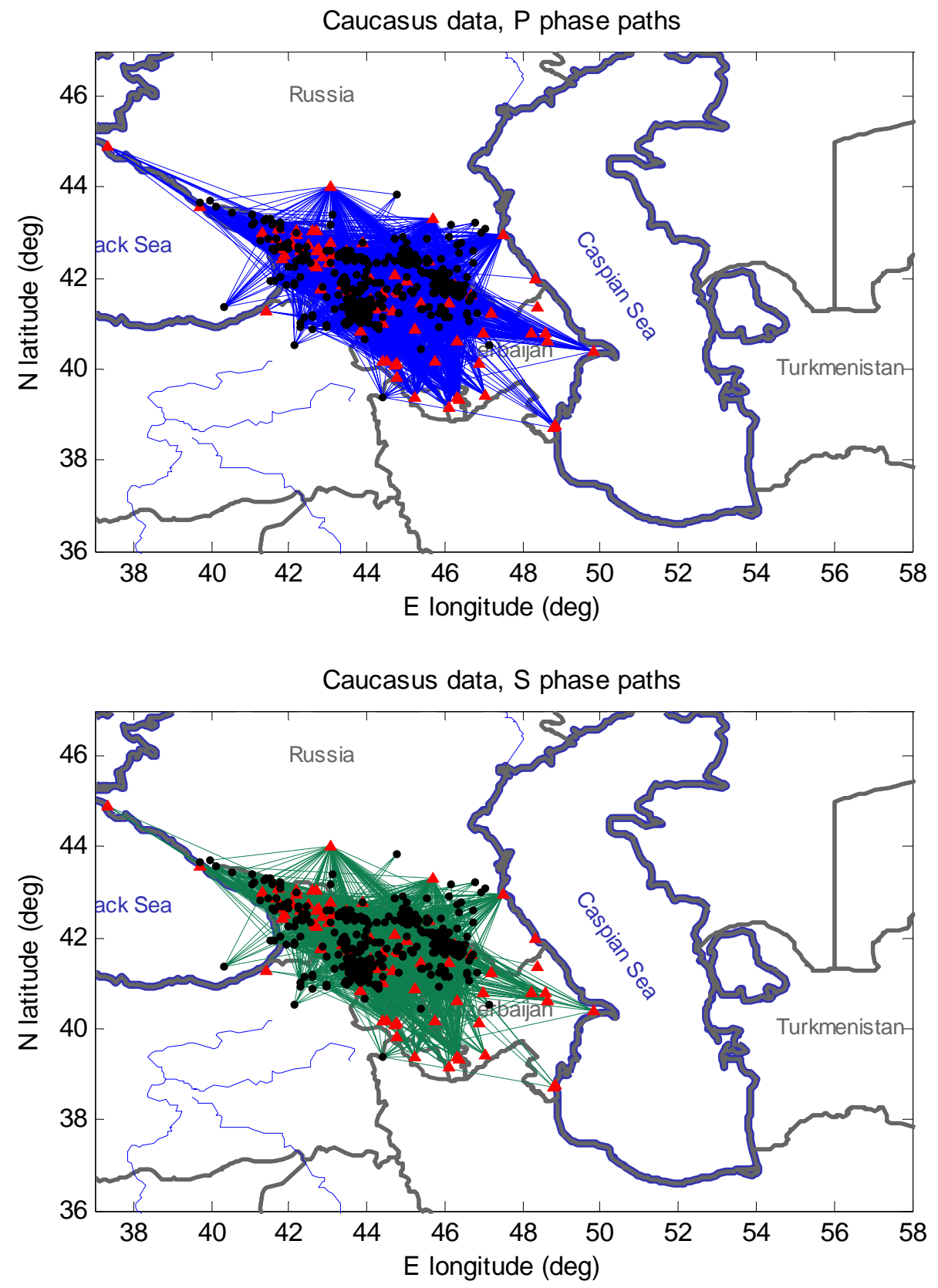

Figure A-5: P (top figure) and S (bottom figure) ray paths in the Caucasus time picks database. These phase picks have largely been done on analog records for events from 1955 to 2002. 

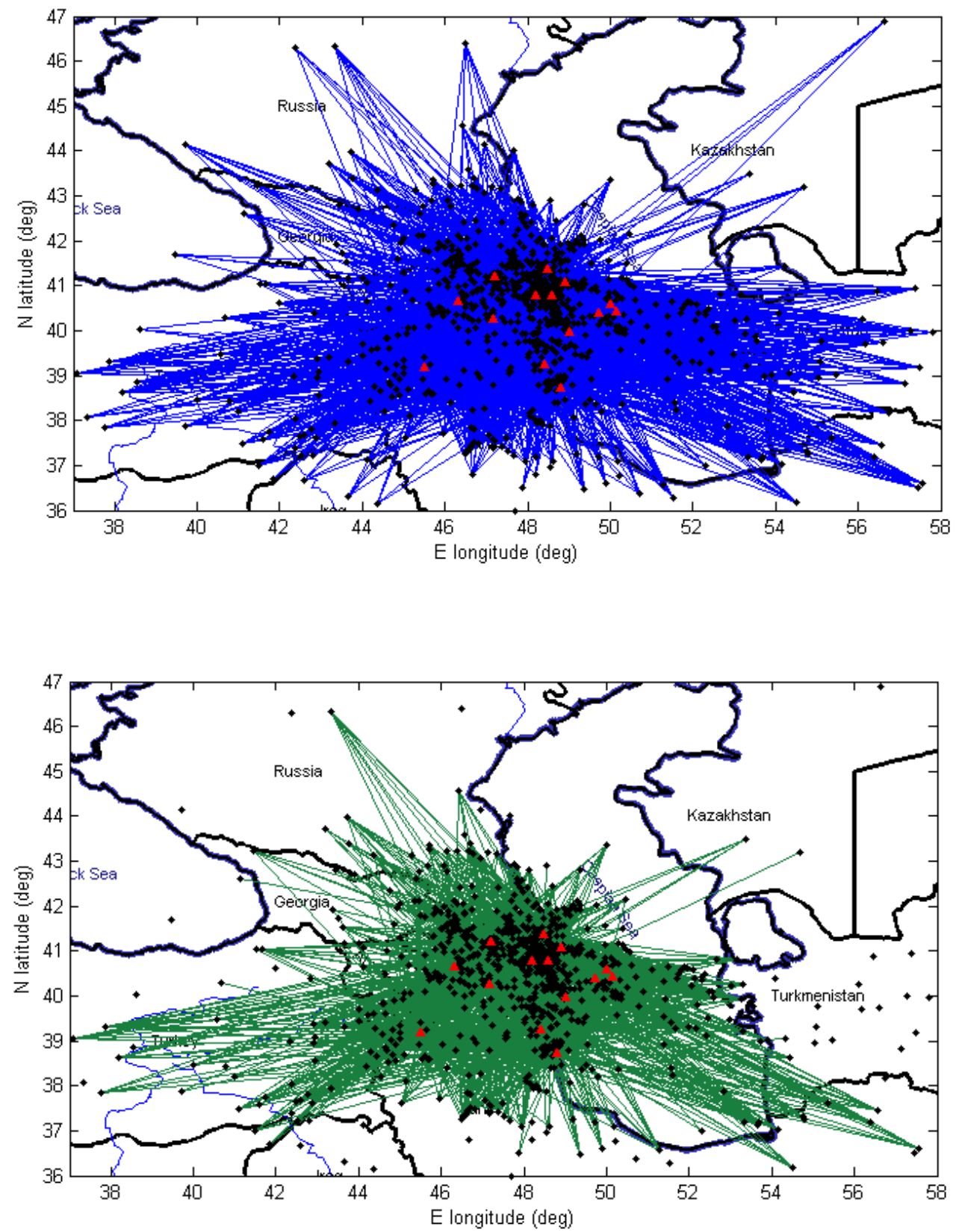

Figure A-6: P (top figure) and S (bottom figure) ray paths in the Azerbaijan time picks database. 